INTERNATIONAL MONETARY FUND

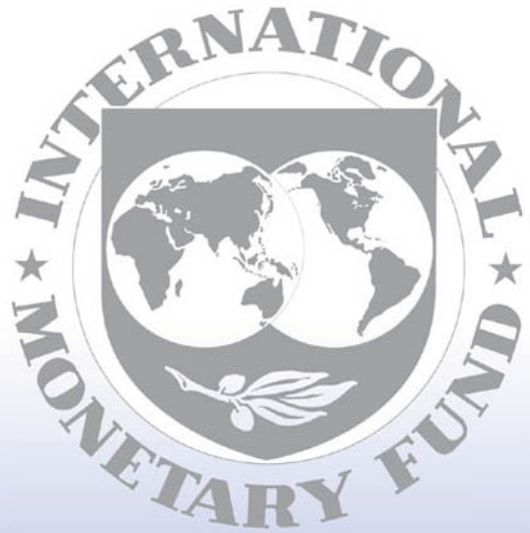

Staff

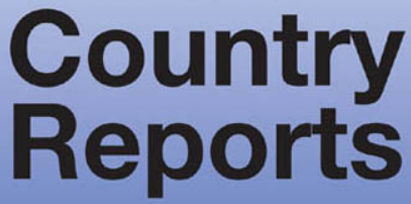


October 2000

IMF Staff Country Report No. 00/128

\section{Mali: Selected Issues and Statistical Annex}

This Selected Issues and Statistical Annex report on Mali was prepared by a staff team of the International Monetary Fund as background documentation for the periodic consultation with this member country. As such, the views expressed in this document are those of the staff team and do not necessarily reflect the views of the Government of Mali or the Executive Board of the IMF,

Copies of this report are available to the public from

International Monetary Fund • Publication Services

700 19th Street, N.W. Washington, D.C. 20431

Telephone: (202) 623-7430 - Telefax: (202) 623-7201

Telex (RCA): 248331 IMF UR

E-mail: publications@imf.org

Internet: bttp://www.imf.org

Price: $\$ 15.00$ a copy

\section{International Monetary Fund}

Washington, D.C. 


\section{INTERNATIONAL MONETARY FUND}

\section{MALI}

\section{Selected Issues and Statistical Annex}

Prepared by a staff team consisting of Mr. De Vrijer (head), Mrs. Kabedi-Mbuyi, Mr. Cady (all AFR), and Mr. Unteroberdoerster (PDR)

Approved by the African Department

August 10, 2000

Contents

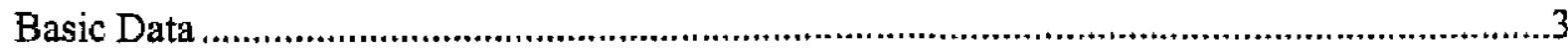

Selected Social and Demographic Indicators ....................................................................

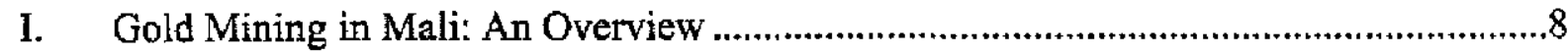

Text Box

1. Key Gold and Mining Sector Indicators, 1992-2002 .................................................17

Text Figures

1. Location of Gold Mines and Artisanal Mining Areas ................................................9

2. Mining Sector Employment by Type of Activity, 1992-99 ...........................................

3. Gold Production by Type of Activity, 1992-99 .........................................................13

$\underline{\text { Statistical Appendix Tables }}$

1. Gross Domestic Product at Constant 1987 Prices, 1994-99 ….....................................19

2. Origin and Use of Resources, 1994-99 ................................................................20

3. Agricultural Production and Average Producer Prices, 1994/95-1998/99

4. Cereals-Cultivated Area and Rainfall, 1994/95-1998/99 _..................................22

5. Quarterly Retail Prices for Cereals, 1994-99......................................................23

6. Office du Niger-Indicators of Activity, 1994/95-1998/99 ….................................24

7. Implementation of the Public Investment Program, 1994-99 ….................................25 
8. Investment Budget for 1994-99 and Existing Commitments for Public

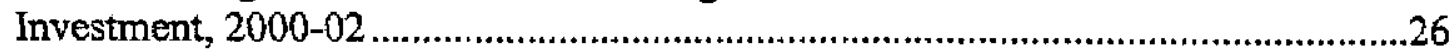

9. Livestock Exports, Slaughtering, and Herd Size, 1994-99 ….....................................22

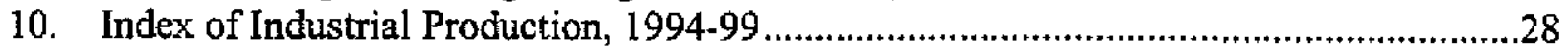

11. Quarterly Index of Consumer Prices in Bamako, 1998-2000 _..................................29

12. Minimum Wages and Salaries in the Public Sector, 1994-99 ...................................... 30

13. Employment in the Central and Regional Governments and the Public Enterprise Sector, 1994-99 …...................................................................31

14. Operating Results of Major Public Enterprises, 1994-99 _........................................32

15. Consolidated Government Operations, 1994-99 ........................................................33

16. Government Revenue, 1994-99 …..........................................................................34

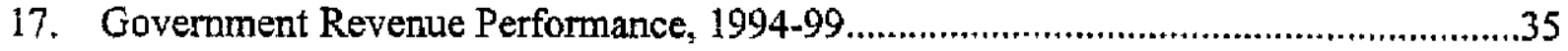

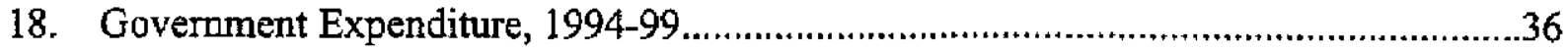

19. Functional Classification of Budgetary Expenditures, 1994-99 .................................37

20. Consolidated Operations of the Special Funds and the Annexed Budgets, 1994-99

21. Government Wage Bill and Employees, 1994-99 .....................................................39

22. Deposit Money Banks, December 1999 ................................................................40

23. Monetary Survey, 1994-99 _..............................................................................41

24. Summary Accounts of the Central Bank, 1994-99 …...............................................42

25. Summary Accounts of the Deposit Money Banks, 1994-99 .......................................43

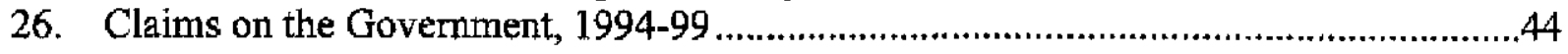

27. Foreign Assets and Liabilities of the Banking system, 1994-99 _..............................45

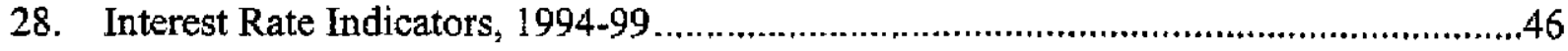

29. Central Bank Discount Rates, November 1989-June 2000 ……..............................47

30. Interest Rates Applied in the Money Market, March 1994-December 1999 ................48

31. Maximum Lending Rates Applied by Commercial Banks, 1994-99 ..........................49

32. Balance of Payments, (in CFA francs), 1994-99 …...................................................50

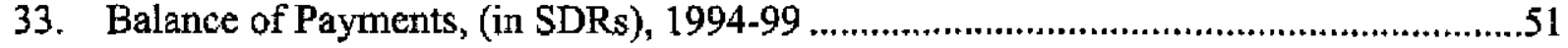

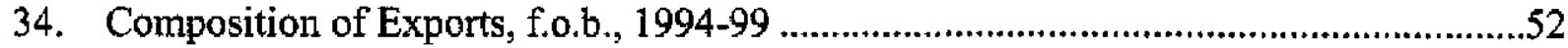

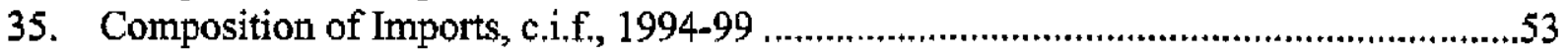

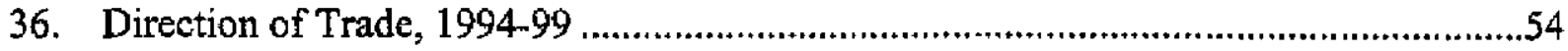

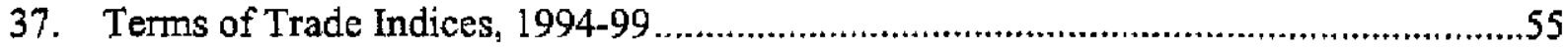

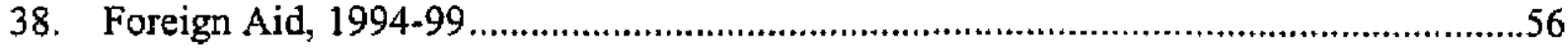

39. External Disbursed Public Debt Outstanding by Creditor, 1994-99 ….......................57

40. Structure and Terms of New Loan Commitments, 1994-99 ..........................................58

41. Debt Service on Medium- and Long-Term External Public Debt, 1994-99....................59

42. Nominal and Real Effective Exchange Rate Indices, 1994-99..................................60

\section{Appendixes}

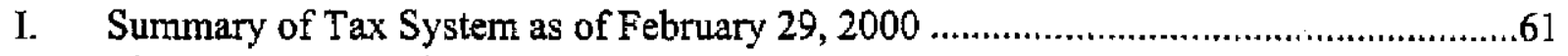
II. List of Selected Public Enterprise Acronyms ..............................................................67 
Mali: Basic Data ${ }^{1}$

Area, population, and GDP per capita

Area

Population (1998)

Growth rate

GDP per capita (1999)
$1,240,190$ square kilometers

10.3 million

2.3 percent

US\$253.2

\begin{tabular}{rrrrrr}
1994 & 1995 & 1996 & 1997 & 1998 & 1999 \\
& & & & & Est. \\
\hline
\end{tabular}

Gross domestic product at

(In billions of CFA francs)

current prices

Total (at current prices)

$\begin{array}{llllll}1,028.7 & 1,231.0 & 1,339.8 & 1,444.7 & 1,553.8 & 1,605.8\end{array}$

(In percent of nominal GDP)

Consumption

Gross domestic savings

Investment

Resource gap

Primary sector

Secondary sector

Tertiary sector

\section{Real GDP \\ Nominal GDP}

\section{Prices}

GDP deflator

Index of consumer prices

in Bamako

33.2

46.0

16.1

33.4

92.9
7.1

92.2

7.8

22.9

$-15.1$

$-18.9$

(In percent of real GDP)

46.9

15.6

32.1

44.7

16.1

33.7

43.7

18.4

32.2

89.6

\section{8}

89.9

7.7

10.4

11.2

10.1

22.9

20.6

20.9

21.2

$-10.2$

$-9.7$

$-11.1$

(Annual change in percent)

2.2

36.2

4.7

19.7

3.2

8.8

6.8

7.8

3.4

7.6

5.5

3.3 
Mali: Basic Data ${ }^{1}$ (continued)

\begin{tabular}{rrrrrrrr}
\hline & 1994 & 1995 & 1996 & 1997 & 1998 & $\begin{array}{r}1999 \\
\text { Est. }\end{array}$ \\
\hline
\end{tabular}

\section{Government finance}

(In billions of CFA francs)

\begin{tabular}{|c|c|c|c|c|c|c|}
\hline Revenue & 122.2 & 157.1 & 206.0 & 229.7 & 254.9 & 272.6 \\
\hline Budgetary revenue & 109.3 & 140.5 & 185.0 & 207.9 & 231.7 & 247.9 \\
\hline \multicolumn{7}{|l|}{ Annexed budgets and special } \\
\hline funds & 12.9 & 16.6 & 20.9 & 21.8 & 23.2 & 24.8 \\
\hline Grants & 97.8 & 92.4 & 96.5 & 84.2 & 89.9 & 83.4 \\
\hline Expenditure and net lending & 266.4 & 289.4 & 314.2 & 345.2 & 383.5 & 417.6 \\
\hline Budgetary expenditure & 268.4 & 291.8 & 303.9 & 328.6 & 363.9 & 395.0 \\
\hline \multicolumn{7}{|l|}{ Of which: externally } \\
\hline financed investment & 115.0 & 133.5 & 137.3 & 124.5 & 149.4 & 347.4 \\
\hline \multicolumn{7}{|l|}{ Annexed budgets and special } \\
\hline funds & 12.9 & 16.6 & 20.9 & 21.8 & 23.2 & 24.8 \\
\hline \multicolumn{7}{|l|}{ Overall deficit, commitment basis } \\
\hline Excluding grants & -144.2 & -132.3 & -108.3 & -115.5 & -128.6 & -145.0 \\
\hline Including grants & -46.4 & -39.9 & -11.7 & -31.3 & -38.7 & -61.6 \\
\hline Overall deficit, cash basis & -76.1 & -54.0 & -30.6 & -39.7 & -48.7 & .59 .1 \\
\hline Financing (net) & 76.1 & 54.0 & 30.6 & 39.7 & 48.7 & 59.1 \\
\hline External (net) & 76.7 & 90.9 & 82.2 & 49.0 & 58.0 & 60.3 \\
\hline Banking system (net) & -4.5 & -37.5 & -46.0 & -1.9 & -4.0 & 1.8 \\
\hline Privatization receipts & 1.8 & 1.3 & 0.3 & 1.4 & 1.2 & 10.4 \\
\hline Other & 2.1 & -0.6 & -5.9 & -8.7 & -6.4 & -13.4 \\
\hline \multicolumn{7}{|l|}{ Monetary survey (end of year) } \\
\hline Net foreign assets ${ }^{2}$ & 110.3 & 147.3 & 212.7 & 211.2 & 175.3 & 138.1 \\
\hline Net domestic assets & 136.2 & 144.8 & 114.0 & 145.6 & 193.9 & 233.8 \\
\hline Credit to the government (net) & 49.1 & 16.6 & -23.6 & -23.9 & -25.9 & $-22,0$ \\
\hline Credit to the economy & 81,0 & 131.1 & 171.2 & 195.9 & 251.0 & 286.5 \\
\hline Other items (net) & 6.1 & -2.9 & -33.6 & -26.4 & -31.2 & -30.7 \\
\hline \multicolumn{7}{|l|}{ Medium- and long-term } \\
\hline extemal habilities & -11.1 & -8.9 & -10.3 & -15.2 & -12.3 & -11.3 \\
\hline Money and quasi money & 237.0 & 283.6 & 317.3 & 345.0 & 359.8 & 364.6 \\
\hline
\end{tabular}


Mali: Basic Data ${ }^{1}$ (contlnued)

\begin{tabular}{|c|c|c|c|c|c|c|}
\hline & 1994 & 1995 & 1996 & 1997 & 1998 & $\begin{array}{r}1999 \\
\text { Est. }\end{array}$ \\
\hline & \multicolumn{6}{|c|}{ (In millions of SDRs) } \\
\hline \multicolumn{7}{|l|}{ Balance of payments } \\
\hline Exports, f.o.b. & 235.0 & 291.2 & 298.1 & 408.1 & 413.9 & 414.2 \\
\hline Imports, c.i.f. & -315.9 & -359.4 & -379.8 & -396.7 & -411.7 & -433.1 \\
\hline Services (net) & -196.7 & -250.5 & -236.1 & -233.9 & -237.5 & -233.3 \\
\hline Of which: interest & -27.5 & $-2 \mathrm{~L} .4$ & -18.7 & -16.4 & -13.9 & $-16,0$ \\
\hline Private transfers (net) & 59.2 & 63.1 & 61.9 & 54.0 & 50.9 & 50.4 \\
\hline $\begin{array}{l}\text { Current account } \\
\text { (excluding grants) }\end{array}$ & -218.4 & -255.6 & -255.9 & -168.5 & -184.4 & $-201,9$ \\
\hline $\begin{array}{l}\text { Untequited public transfers } \\
\text { (net) }\end{array}$ & 169.0 & 147.1 & 167.1 & 119.9 & 126.0 & 110.4 \\
\hline \multicolumn{7}{|l|}{ Current account } \\
\hline Capital (net) & 57.5 & 80.7 & 97.1 & 24.9 & 30.5 & 58.1 \\
\hline Official capital (net) & 31.2 & 60.9 & 55.5 & 42.0 & 72.5 & 71.6 \\
\hline Disbursements & 115.3 & 145.4 & 137.5 & 90.6 & 104.9 & 109.0 \\
\hline Amortization & -84.1 & -84.5 & -82.0 & -48.6 & -32.4 & -37.3 \\
\hline Private capital (net) & 26.3 & 19.8 & 41.6 & -17.1 & -42.0 & -13.5 \\
\hline Debt relief & 65.2 & 59.2 & 55.2 & 0.9 & 0.0 & 0.0 \\
\hline Errors and omissions & 12.3 & 13.2 & 24.5 & -10.2 & -17.1 & -7.2 \\
\hline Overall balance & 85,7 & 44.6 & 88.0 & -33.0 & -45.0 & -40.7 \\
\hline \multicolumn{7}{|l|}{ Foreign assets (net) } \\
\hline (increases -) & -60.6 & -49.0 & -87.9 & 15.1 & 45.0 & 44.2 \\
\hline Of which: $\mathrm{MF}$ (net) & 22.3 & 24.3 & 15.7 & 15.6 & 2.3 & 8.8 \\
\hline Revaluation adjustment & 0.0 & 4.4 & 0.0 & 0.0 & 0.0 & -3.6 \\
\hline Debt under negotiation/moratoriu & 0.0 & 0.0 & 0.0 & 18.2 & 0.0 & 0.0 \\
\hline \multicolumn{7}{|l|}{ Changes in payments arrears } \\
\hline Reduction $(-)$ & -24.9 & 0.0 & 0.0 & 0.0 & 0.0 & 0.0 \\
\hline \multicolumn{7}{|l|}{$\begin{array}{l}\text { International reserves and } \\
\text { liabilities (end of year) }\end{array}$} \\
\hline Gross reserves & 232.9 & 327.3 & 391.5 & 412.7 & -19.9 & -15.1 \\
\hline Gross liabilities & 95.5 & 162.6 & 162.8 & 190.3 & 203.6 & 244.9 \\
\hline
\end{tabular}


Mali: Basic Data ${ }^{1}$ (concluded)

\begin{tabular}{rrrrrrrr}
\hline 1994 & 1995 & 1996 & 1997 & 1998 & 1999 \\
& & & & & & \\
\hline
\end{tabular}

(In millions of SDRs)

Outstanding external debt

\begin{tabular}{|c|c|c|c|c|c|c|}
\hline (end of period) & 1,790 & 1,915 & 2,023 & 2,137 & 2,174 & 2,213 \\
\hline Of which: Fund credit & 74.1 & 99.0 & 114.6 & 130.2 & 132.5 & 140.9 \\
\hline
\end{tabular}

Debt-service ratio

$\begin{array}{crrrrrr}\text { Scheduled debt service }^{3} & 22.9 & 16.4 & 15.1 & 11.1 & 11.4 & 12.9 \\ \text { Excluding the Fund } & 20.2 & 14.9 & 13.3 & 9.8 & 9.5 & 11.0\end{array}$

(CFA francs per SDR and per U.S. dollar)

\begin{tabular}{|c|c|c|c|c|c|c|}
\hline \multicolumn{7}{|l|}{ Exchange rates } \\
\hline \multicolumn{7}{|l|}{ Period average } \\
\hline SDR & 795.0 & 757.1 & 742.8 & 803.1 & 800.0 & 841.7 \\
\hline U.S. dollar & 555.2 & 499.2 & 511.6 & 583.7 & 590.0 & 615.7 \\
\hline \multicolumn{7}{|l|}{ End of period } \\
\hline SDR & 780.4 & 728.4 & 753.1 & 807.9 & 791.6 & 896.2 \\
\hline U.S. dollar & 534.6 & 490.0 & 523.7 & 598,8 & 562.2 & 653.0 \\
\hline \multicolumn{7}{|c|}{$\begin{array}{l}\text { Trade-weighted effective } \\
\text { exchange rate index }\end{array}$} \\
\hline Nominal & 53.4 & 55.3 & 55.1 & 53.0 & 53.9 & 52.7 \\
\hline Real (CPI based) & 55.1 & 62.0 & 64.1 & 60.2 & 63.0 & 60.4 \\
\hline
\end{tabular}

'Data may not add up owing to rounding.

${ }^{2}$ Excluding SDR allocations and medium- and long-term liabilities.

'In percent of exports of goods and nonfactor services; after debt cancellation; before debt relief; excluding debt service due to the People's Republic of China and Russia. 
Malí: Selected Social and Demographic Indicators ${ }^{1}$

\section{Area}

Total (sq. km.)

Agricultural (percent of total)

Of which : under irrigation

Population (1998)

Total (million)

Average rate of growth (percent a year)

(1993-98)

Population sharacteristics

Cnude birth rate (per thousand; 1998)

Crude death rate (per thousand; 1998)

Urban population (percent of total; 1998)

Access to safe water

$\begin{array}{lcc} & 1988 & 1997 \\ \text { In percent of population } & & \\ \text { Total } & 22.7 & 19.8 \\ \text { Urban } & 48.0 & 55.6 \\ \text { Rural } & 17.0 & 48.3\end{array}$

Nutrition
Per capita supply of:
Calories (per day)
Proteins (grams per day)

Gross national product (1998)

Per capita (USS)

(World Bank Atlas methodology)

250

0.24

Population density

General density (per sg, km.)

8.6

Density per sq. km. of agricultural land

32.4

46.6

15.9

30.4

\section{Health}

Population per physician (in thousands, 1996)

16.7

Population per hospital bed (1998)

Infont mortality rate (per thousand

live births) (1998)

Education

118.0
Enrollment rates (in percent of school-age population) Primary (1999) $\quad 50.0$ Secondary (1995) $\quad 10.1$
Pupil-teacher ratio (in percent) Primary (1995) 69.7 Secondary (1994) $\quad 16.0$

Sources: World Bank, Social Indicators of Development, 1999; African Development Indicators, 1999/2000; World Development Indicators, 2000 CD-ROM; and Fund staff estimates.

${ }^{3}$ Latest single year between 1990 and 1998, unless otherwise indicated. 


\section{Gold MINING In MALI: AN OVERVLEW ${ }^{1}$}

\section{A. Introduction}

1. The rapidly expanding gold mining industry in Mali provides an example of what resource endowments, combined with a stable environment and globally competitive sectoral policies, can yield. Endowed with significant gold deposits but starting from a virtually unregulated artisanal industry less than two decades ago, Mali has developed into Africa's third-largest gold producer and exporter, after South Africa and Ghana. ${ }^{2}$ Since 1991, with the reform of the Mining Code, Mali has succeeded in creating an environment attractive to international exploration and mining companies. Gold mining now represents an engine of growth for the Malian economy, contributes significantly to the public finances, and, to a more limited extent, creates modern sector jobs.

2. Gold mining represents a Malian artisanal tradition, dating from about the seventh century, that is still practiced to a significant degree today. The era of industrial gold mining began in 1984 with the opening of a government-owned open pit mine at Kalana. Later in the 1980 s the mining sector was opened to private and foreign investors; however, foreign mining companies initially exhibited little interest, owing to the government's interventionist policies and the absence of a clear, consistent, and globally competitive mining policy.

3. Since the introduction of a new Mining Code in September 1991, broadly reflecting internationally accepted standards, and the arrival of a democratically elected government in 1992, the gold mining industry in Mali has grown rapidly. Following the commissioning of the Sadiola Hill mine in 1997, gold became Mali's second most important export commodity, after cotton. Currently, gold is mined at Sadiola Hill and Syama (industrial operations) and in the Kenieba and Kangaba regions (artisanal mining areas, see Figure 1). Gold represents Mali's most important mineral resource, with estimates of reserves ranging between 500 and

\footnotetext{
${ }^{1}$ Prepared by Mr. John Cady; assistance in the area of mining legislation was provided by Mr. Craig Andrews, Principal Mining Specialist at the World Bank.

${ }^{2}$ Based on officially recorded exports, Mali recently surpassed Zimbabwe to claim the third rank.
} 
Figure 1. Mali: Location of Gold Mines and Artisanal Mining Areas

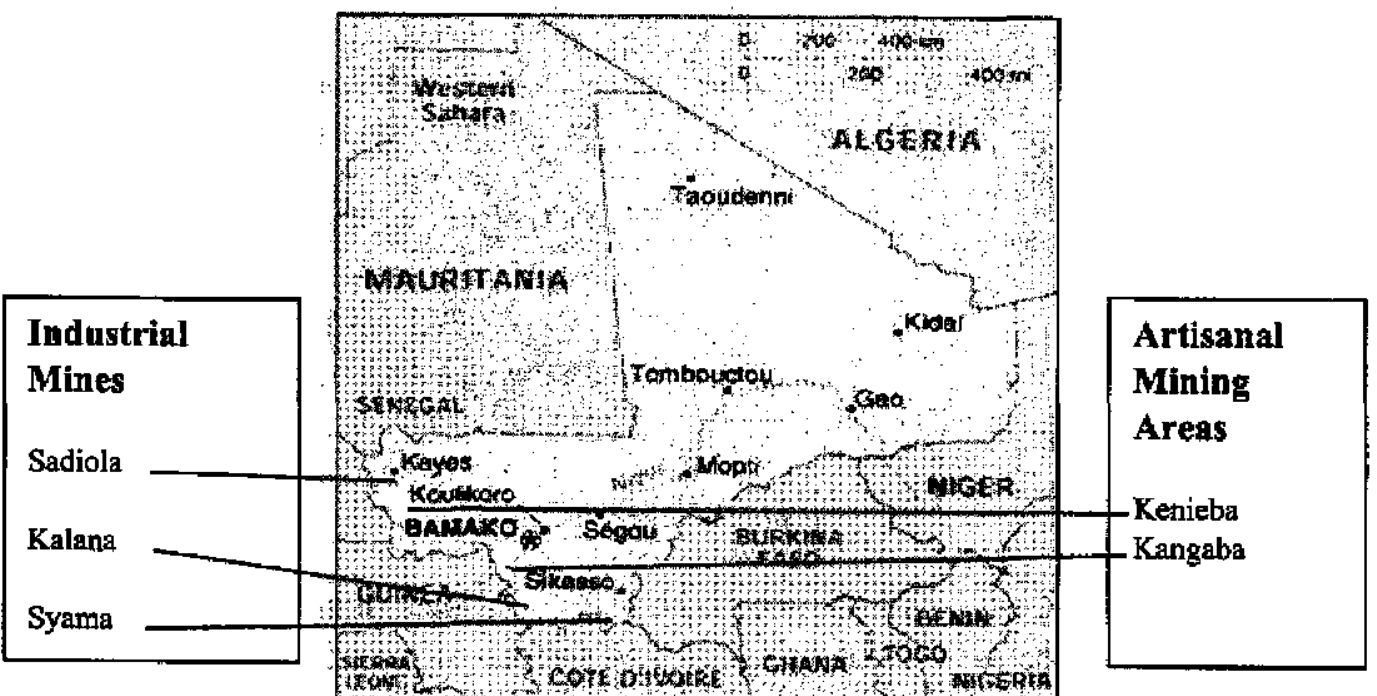

Figure 2. Mali: Mining Sector Employment by Type of Activity, 1992-99

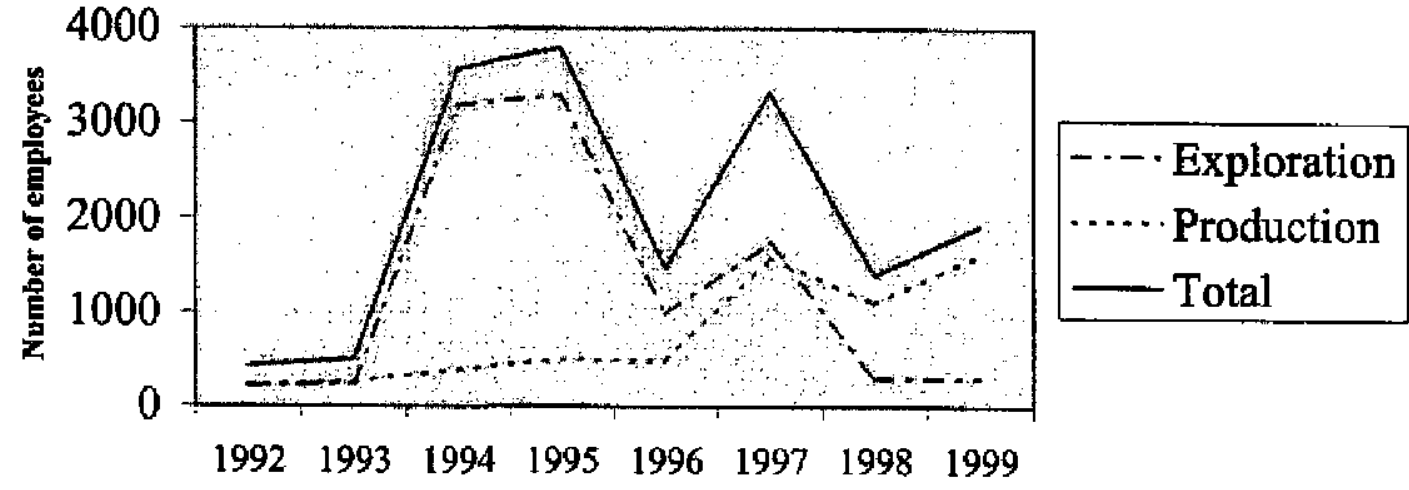

Sources: Société d'Exploitation des Mines d'Or de Sadiola SA (SEMOS), Société des Mines d’Or de Syama SA (SOMISY), and the Malian authorities. 
700 metric tons. ${ }^{3}$ Deposits of other mineral resources exist throughout Mali but remain largely undeveloped or of limited commercial significance. ${ }^{4}$

4. The remainder of this note is organized as follows. A description of the techniques and importance of artisanal gold mining in Mali is provided in Section B. Sections C and D respectively trace the key developments of the industrial mining era and outline potential gold mining developments. Section $\mathrm{E}$ describes the key government and regulatory institutions involved with mining, while section $F$ describes current Malian mining policy and regulations. Section $\mathrm{G}$ describes of the impact of industrial gold mining on the Malian economy, public finances, and employment. The final section concludes with some comments about prospects for the gold mining industry in Mali.

\section{B. Artisanal Gold Mining}

5. Artisanal gold mining has been practiced continuously for more than a thousand years in Mali. It currently serves as a source of livelihood for an estimated 150,000 seasonal miners, a significant proportion of whom are women. ${ }^{5}$ About 250 sites located in the southern and western parts of the country are exploited on an artisanal basis.

6. Artisanal gravel-mining techniques involve digging underground mines with hand picks; crushing the gold-bearing ore with metal mortar and pestle; and separating the gold from the ore using water in a calabash (gourd) with hand action (similar to the classic "panning" technique). These methods are not efficient, with an estimated 50 percent of the ore left in the ground as pillars to support galleries, while the washing process fails to recover more than 20 percent of the gold because the particles are too fine to be collected by hand.

7. Artisanal miners tend to operate under what are generally considered unsafe conditions. Although safety records are not maintained, cave-ins and suffocation are reportedly high, especially at the outset of the rainy season. Some artisanal hard-rock mining, employing pneumatic drills and explosives, are done on a limited basis. Malian artisanal

${ }^{3}$ Metric weights and measures are used throughout this note, with the exception of costs and prices, which are conventionally cited in U.S. dollars per troy ounce. For ease of exposition, all references to tons should be interpreted as meaning "metric tons." A metric ton contains 32,150 troy ounces.

${ }^{4}$ According to the World Bank, Mali has significant geological potential. In addition to gold deposits, Malian geological structures are favorable for deposits of diamonds, base metals, phosphates, manganese, and uranium. Some fossil fuel deposits have been identified, as have significant reserves of bauxite, but these remain undeveloped, in part owing to the distances from markets and insufficient transportation infrastructure. A small phosphate mine operated in Mali for several years prior to its closure in 1999.

${ }^{5}$ Estimates according to the Direction Nationale de la Géologie et des Mines. 
miners do not generally utilize chemical separation processes (mercury and cyanide) to extract gold from ores.

8. Under the current mining law, artisanal miners are recognized, but they can neither apply for mining permits nor be conferred mineral rights. Artisanal miners therefore risk expulsion from a property if it is granted to a legal permit holder. Despite the potential for legal difficulties, most of the problems typically associated with "gold-rush" style artisanal mining appear to be minimized in the Malian context, as the artisanal miners are well organized under their customary village structures and laws.

9. Until 1990, artisanal miners produced most Malian gold, with artisanal production exceeding that of the industrial operation at the Kalana mine. Estimates of annual artisanal production and exports range between 2 and 3 tons for the period $1987-90$ and about 2 tons for the period 1990-99. ${ }^{6}$ The value of artisanal gold exports in 1999 was estimated at CFAF 9.6 billion (approximately 0.6 percent of GDP and equivalent to about US\$11 million).

\section{Industrial Gold Mining}

10. As mentioned above, Kalana was the first industrial gold mine developed in Mali. It was operated from 1984 until 1991 by the Sociétié de Gestion et d'Exploitation des Mines d'Or de Kalana (SOGEMORK), a public enterprise, with Soviet technical assistance. The mine generally produced less that $\mathbf{5 0 0}$ kilograms of gold per year, as opposed to the 2 tons annually that had been anticipated. Profitability and production reportedly suffered owing to significant errors in grade evaluation and mine operation. The Kalana mining operations ceased in 1991, and SOGEMORK was liquidated in 1992.

11. Mati's first privately operated industrial gold mine was commissioned in 1990 at Syama in southem Mali. The Syama mine ${ }^{7}$ was originally developed by BHP-Utah (Broken Hill Proprietary Company, Australia). Hampered by technical production difficulties and low profitability for several years, BHP-Utah sold its participation in the mine to Randgold Resources (South Africa) in 1996. Subsequent to taking over the Syama mine, Randgold undertook a new investment program aimed at reducing operating costs through increased throughput. This program has resulted in a reduction of production costs to about US $\$ 210$

\footnotetext{
${ }^{6}$ For 1987-90, the estimates are from the Ministère des Mines, de l'Energie, et de l'Eau; for the period 1990-99, the figures are balance of payments estimates, prepared by the Central Bank of West African States (BCEAO). Artisanal gold production estimates are acknowledged as not being reliable due to smuggling.

${ }^{7}$ Owned by La Société des Mines d'Or de Syama SA (SOMISY). Participation in the capital of SOMISY at end-1999 was as follows: Randgold Resources (South Africa), 75 percent; the government of Mali, 20 percent; and the International Finance Corporation (IFC), 5 percent.
} 
per ounce, thereby returning the mine to profitability at current international gold prices (the London gold fix averaged US\$279 per ounce in 1999 and about US\$288 per ounce over the first half of 2000). Production rose to 6.1 tons in 1999, an increase of some 56 percent over the average of 4 tons produced during 1993-98. However, the Syama mine has continued to encounter operating difficulties. A feasibility study is being conducted to ascertain whether the mine should be expanded to an underground operation to take advantage of the remaining reserves, estimated as sufficient for another six or seven years of production.

12. At present, Mali's largest gold mining operation is the Sadiola Hill mine, ${ }^{8}$ which has been operated by Anglo-American (South Africa) since its commissioning in early 1997.

Sadiola is also reported to be the second-largest gold mine in West Africa. Production, all of which is exported, has increased from $121 / 4$ tons in 1997, the initial year of operations, to $15 \%$ tons in 1998 and 17 tons in 1999 (Figure 3). On the basis of the original public estimates of reserves, the mine was expected to produce a minimum of 10 tons annually for approximately 13 years. The ores mined at Sadiola are relatively concentrated, yielding estimated costs of production over the $1997-99$ period of US $\$ 125-165$ per ounce, thus making the mine quite profitable.

13. The gold-mining operations ${ }^{9}$ at the Morila site began prestripping operations in February 2000 and are on track for commissioning in the third quarter of this year. Full production and exports are set to begin either later this year or in early 2001 . This mine is expected to produce some 7 to 10 tons of gold annually over an expected life of approximately 14 years. Average operating costs are expected to be about US\$137 per ounce over the life of the project, well below current world market prices, virtually ensuring that the project remains economically viable even in the event of a significant world price decline.

\footnotetext{
${ }^{8}$ Owned by La Société d'Exploitation des Mines d'Or de Sadiola SA (SEMOS). Participation in the capital of SEMOS at end-1999 was as follows: Anglo-American (South Africa), 38 percent; Iamgold (Canada), 38 percent; the government of Mali, 18 percent; and the International Finance Corporation (IFC), 6 percent.

${ }^{9}$ Owned by La Société d'Exploitation des Mines d'Or de Morila SA (SEMOM). Participation in the capital of SEMOM at end-1999 was as follows: Randgold Resources (South Africa), 80 percent; and the government of Mali, 20 percent. In April 2000, Randgold Resources sold 50 percent of its participation to AngloGold, a subsidiary of Anglo-American, which became the mine operator in mid-2000.
} 


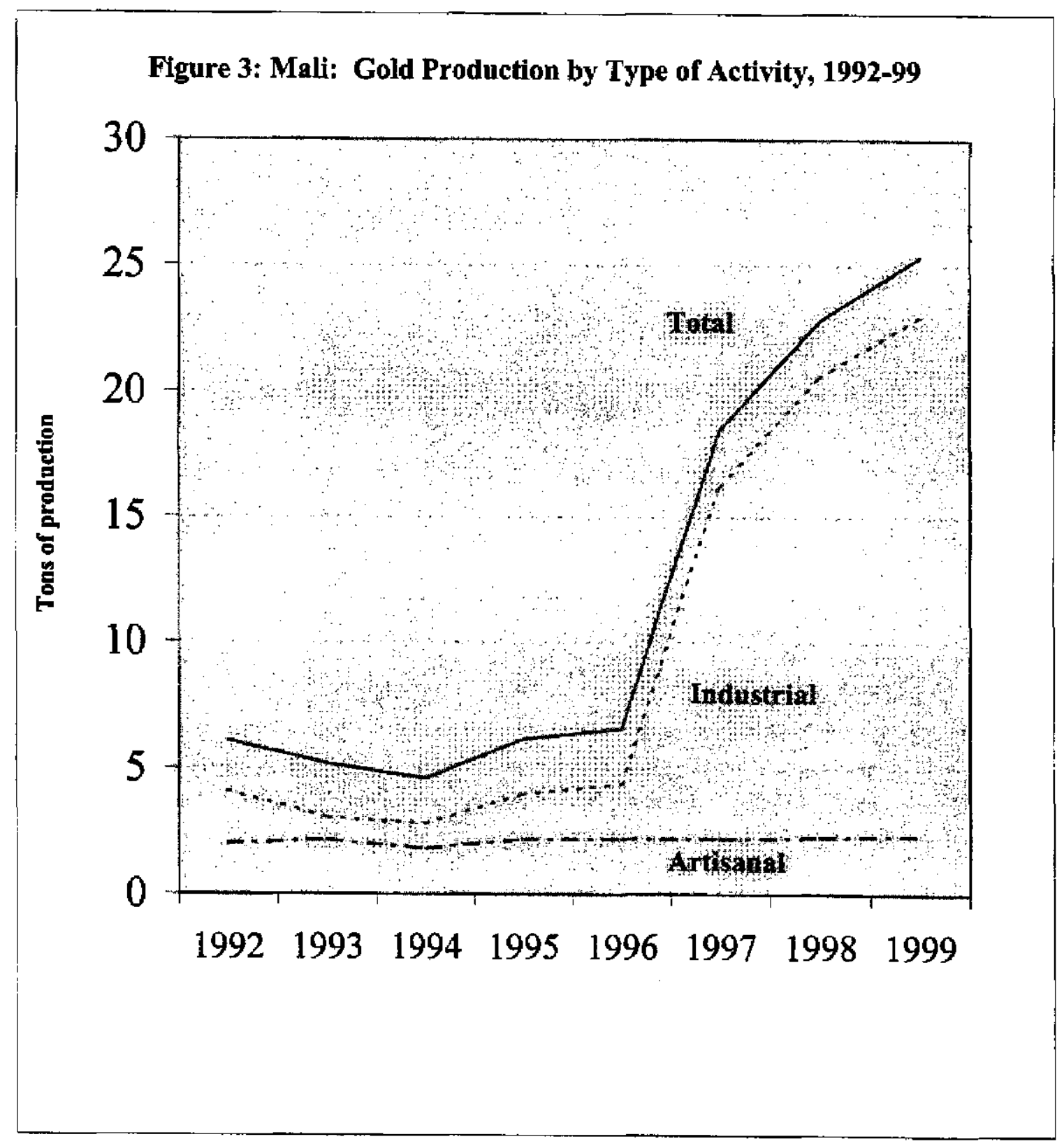

Sources: Central Bank of West African States (BCEAO); and Malian authorities. 
14. AngloGold (South Africa) and Iamgold (Canada) have recently formed a joint venture and announced plans to develop a mine at the Yatela deposit, with operations set to begin in 2001. This mine is located about 25 kilometers from Sadiola, and plans call for the Sadiola refining facilities to process ores mined at Yatela. Based on reserves estimated at about 80 tons, the mine will have an estimated life of about 12 years, assuming an annual production rate of about $6 \frac{1}{2}$ tons.

\section{Potential Gold Mining Developments and Mineral Exploration}

15. The Malian mining company SODINAF is reportedly developing an open cast gold mine in the Kodieran concession, which it expects to yield 3-5 tons of gold per year for approximately eight years. The Malian government is also actively seeking to privatize the Kalana mine, in light of foreign investor interest in redevelopment. ${ }^{10}$ Potential future developments include the following concessions, with estimated reserves in tons noted in brackets: Loulo (70-80); Segala (50-60); and Kalana (20-25).

16. Currently, mineral exploration activity in Mali is dominated by gold, but it also includes some exploration for diamonds, fossil fuels, and other minerals. In July 2000 , more than 50 domestic and foreign companies were exploring under close to 90 permits, compared with only 12 exploration permits in 1990. However, it is unclear how many permits are actively being explored, as opposed to simply being held for speculative purposes. Worldwide gold exploration expenditures have dropped significantly since 1998, following the decline in the price of gold, and Mali, along with other African countries, has suffered some slowdown in active exploration.

17. Based on the production capacities of the two existing gold mines, the two mines currently under construction, and conservative estimates for artisanal production, Mali has the potential to export about 25-35 tons of gold annually over the medium term. On the assumption of world gold prices remaining near US $\$ 280$ per ounce, this production level should be sufficient to maintain the value of gold exports in the range of CFAF 150-210 billion per year (approximately US $\$ 240-340$ million, based on mid-2000 exchange rates). Over the longer run, and on the basis of conservative reserve estimates alone (abstracting from cost, price, and other considerations), firms operating in Mali should be able to maintain or exceed exports of 20-25 tons of gold annually until 2020 . Thus, on the basis of known and proven gold reserves, current policies, and the assumption that world gold prices will remain near their current levels, Mali can reasonably be expected to remain an important African gold exporter for some time to come.

${ }^{10}$ In 1995, mining rights to the Kalana property were granted to Ashanti Goldfields (Ghana); however, with no progress made in redevelopment, the concession was not renewed in 1999, and the government is seeking new investors. 


\section{E. Sector Institutions}

18. Overall responsibility for the mining sector lies with the Ministère des Mines, de l'Energie, et de l'Eau, which developed and implemented mining policies initially through the Société Nationale de Recherche et d'Exploitation Minière (SONAREM) and subsequently through the Direction Nationale de la Géologie et des Mines (DNGM). SONAREM was created shortly after independence in 1960 and, reflecting Mali's interventionist approach to development at that time, was given a monopoly on the exploration and development of the countries' mineral resources. Between 1963 and 1969, it was active in exploring and mapping Malian territory, but limited development occurred. With the transfer of responsibility for the development of mining policy to the DNGM in 1967 and the promulgation of the 1970 Mining Code, SONAREM's hegemony diminished.

19. Nevertheless, SONAREM continued to play a significant role in the sector. It was responsible for the development of the Kalana mine, as well as operations following commissioning in 1984; in 1985, however, ownership and operation of the mine were transferred to SOGEMORK. SONAREM also created a phosphate mining company, Marbres et Eaux Minérales de Mali, which ceased operations in 1999. In January 2000, the government adopted a draft law authorizing SONAREM's liquidation.

20. Today, the DNGM is responsible for formulating most aspects of mining policy, ${ }^{11}$ regulation of the sector, and the granting of exploration and mining permits. It also acts as the manager of the government's participation in the financial capital of mining ventures. Finally, the DNGM is responsible for conducting Mali's geological survey.

\section{F. Legal and Mining Taxation Frameworks}

21. Since 1970, mining in Mali has been regulated by legislation. Supported by the World Bank, this legislation was significantly reformed in 1991 and modified again in late 1999. The revisions introduced in 1999 reduced the number of mining titles and streamlined the permit issuance process. The revisions also substantially altered the taxation regime applicable to mining by shifting the tax burden from inputs and production toward profits. Thus, the royalty on gold production was reduced from 6 percent to 3 percent and customs duties were lowered, in line with the West African Economic and Monetary Union common external tariff. The tax holidays on corporate income and import duties during the initial years of production were eliminated and a dividend withholding tax applied. Regulations concerning government participation in the capital of the mining enterprises (back-in rights) were also modified. These policy changes were designed to foster the development of new gold deposits and, at the same time, increase government revenue from the sector.

${ }^{11}$ Mining tax policy is jointly developed with the Ministry of Economy and Finance. 
22. Since 1991, Mali has made use of a model investment agreement to accelerate the process of negotiating and awarding permits for mining exploration. The standard agreement serves as a point of departure for negotiations with foreign and private operators and fixes fiscal obligations such as income taxes, tax exemptions, depreciation allowances, and royalties. While actual mining agreements are negotiated and could vary substantially, key features of the current model agreement are as follows:

- Permits. Exploration permits are issued by the Minister of Mines for a period of three years, with a 50 percent reduction on the surface area at the discretion of the holder at the end of the second year of the first tenure. Exploration permits are twice renewable for three-year periods over a certain area, which again are reduced by half each time. Mining permits are granted by decree for a maximum of 30 years, including renewals, to applicants with provable, bona fide ore bodies.

- Capital. Earnings are freely repatriated.

- Taxes. Mining ventures are subject to the 35 percent corporate income tax (the previous law provided a corporate income tax holiday for the first five years of production). Depletion allowances are set at $271 / 2$ percent of gross sales proceeds. Imports used for exploration are taxed at a zero rate, while imports used for production are subject to normal duties (the 1991 code granted duty exemptions to cover the first three years of production). Gold production attracts a 3 percent ad valorem tax (under the 1991 law, gold production attracted a 3 percent royalty and a 3 percent production tax).

- Rights to government participation. The government's "back-in rights" were also modified in 1999. The government of Mali now reserves the right to participate as a shareholder in the capital of a mining company to the extent of a maximum carried interest of 10 percent, free of financial obligations, but with the right to preferential dividends, and the option to acquire an additional 10 percent working interest through a contribution to the financial capital of the venture. Under the 1991 mining law, the government retained rights to a maximum 20 percent participation through a combination of a 15 percent carried interest and 5 percent working interest.

\section{G. The Impact of Gold Mining on the Malian Economy}

23. In 1984, the first year of operations at the Kalana mine, the mining sector accounted for an estimated 11/2 percent of Mali's GDP. In 1990, the first year of operation of the Syama mine and the final year of production at Kalana, gold mining accounted for just over 2 percent of GDP, and about 14 percent of total export receipts. During the period 1992-99, the share of gold mining in GDP more than doubled, from $2 \frac{1}{4}$ percent to $5 \frac{3}{4}$ percent, and the value of gold exports rose from 16 percent of goods exports to more than 40 percent. Tax receipts from the sector increased from $3 \frac{1 / 2}{2}$ percent of total government revenue in 1995 to $71 / 4$ percent by 1999 (Box 1). In the future, tax receipts from the sector will likely increase further as existing tax holidays expire, new mines come onstream, and the tax measures 
contained in the 1999 Mining Code begin to take effect. Additionally, the Malian government could benefit from dividends from its ownership position in mining ventures, as it did in 1999 when SEMOS paid the government a dividend of close to CFAF 1 billion (approximately US\$1.5 million).

\begin{tabular}{|c|c|c|c|c|c|c|c|c|c|c|c|}
\hline \multicolumn{12}{|c|}{ Box 1. Mali: Key Gold and Mining Sector Indicators, 1992-2002 } \\
\hline & 1992 & 1993 & 1994 & 1995 & 1996 & 1997 & 1998 & 1999 & & \multicolumn{2}{|c|}{ Projections } \\
\hline Gold production' & 6.1 & 5.2 & 4.6 & 6.2 & 6.6 & 18.5 & 22.5 & 25.3 & 26.4 & 32.2 & 36.2 \\
\hline Industrial & 4.0 & 3.1 & 2.8 & 4.0 & 4.4 & 16.3 & 20.6 & 23.1 & 24.1 & 29.9 & 33.8 \\
\hline Artisanal & 2.1 & 2.1 & 1.8 & 2.2 & 2.2 & 2.2 & 2.3 & 2.3 & 2.3 & 2.4 & 2.4 \\
\hline Gold exports ${ }^{2}$ & 16.1 & 15.4 & 14.9 & 16.1 & 18.0 & 35.7 & 40.2 & 40.9 & 45.0 & 46.4 & 44.4 \\
\hline Mining $\mathrm{GDP}^{3}$ & 2.2 & 2.2 & 2.0 & 2.0 & 2.1 & 4.6 & 5.5 & 5.7 & 5.7 & 6.6 & 7.0 \\
\hline Tax payments ${ }^{4}$ & $\ldots$ & $\ldots$ & $\ldots$ & 3.6 & 4.7 & 7.7 & 7.8 & 7.3 & $\ldots$ & $\ldots$ & $\ldots$ \\
\hline Persons & 425 & 502 & 3,570 & 3,798 & 1,472 & 3,332 & 1,400 & 1,921 & $\ldots$ & $\ldots$ & $\ldots$ \\
\hline Share" & 1.1 & 1.4 & 10.9 & 11.7 & 4.1 & 8.9 & 3.7 & 5.0 & $\ldots$ & $\cdots$ & $\cdots$ \\
\hline $\begin{array}{l}\text { Sources: Malian auth } \\
\text { I In tons. } \\
{ }^{2} \text { Value of gold expor } \\
{ }^{3} \text { Percent of GDP. } \\
{ }^{4} \text { SEMOS and SOMI } \\
{ }^{5} \text { As a share of moder }\end{array}$ & $\begin{array}{l}\text { orities; } \\
\text { its as a } \\
\text { ISY dine } \\
\text { m sector }\end{array}$ & $\begin{array}{l}\text { MOS; SC } \\
\text { centage c } \\
\text { and indir } \\
\text { mployme }\end{array}$ & $\begin{array}{l}\text { MISY, and } \\
\text { the value } \\
\text { t tax paym } \\
\text {, which, is }\end{array}$ & $\begin{array}{l}\text { taff estim } \\
\text { all expor } \\
\text { nts as pen } \\
\text { arn, acco }\end{array}$ & $\begin{array}{l}\text { ent of tot } \\
\text { nts for al }\end{array}$ & $\begin{array}{l}\text { jections. } \\
\text { governme } \\
\text { ut } 10 \text { perc }\end{array}$ & $\begin{array}{l}\text { trevenue. } \\
\text { it of the la }\end{array}$ & force. & & & \\
\hline
\end{tabular}

24. Employment in the industrial mining sector increased from fewer than 500 persons in 1992 to over 1,900 in 1999. Most employees are involved in gold exploration and production activities, half of whom at the Sadiola and Syama mines. Between 1992 and 1999, mining sector employment, measured as a share of formal sector employment, varied substantially, from a low of about 1 percent in 1992 to a high of almost 12 percent in 1995 . With the formal sector employing an estimated 10 percent of the Malian labor force in 1999, about $1 / 2$ of 1 percent of the labor force was employed in the mining sector. Figure 2 presents mining sector employment by type of activity and illustrates the rapid increase of employment since 1992, as well as the volatile nature of employment in exploration activities. During 1999, average employment levels at SOMISY were as follows: 728 Malians and about 70 expatriates were employed on a full-time basis, as well as over 300 Malians on a temporary basis. Total employment at SEMOS, operator of the Sadiola mine, was about 1,250 , comprising almost 1,100 Malians and 150 expatriates (with about 875 employed at the mine site). As mentioned above, artisanal gold mining accounts for the seasonal employment of up to 150,000 people. 
25. The growing importance of gold mining and the prospects for future development point to a growing need for more detailed information on the sector to assist in the assessment of the sector's contribution to the economy and the formulation of appropriate mining policies. Currently, there is scant evidence about the impact of gold mining on the Malian economy. Some estimates suggest that in 1997 about CFAF 9 billion (about $1 / 2$ of 1 percentage point of GDP) in salaries were paid to the employees of SEMOS and SOMISY, with over 75 percent paid to Malian nationals. In addition, local purchases made by mining companies involved in both production and exploration have been estimated at about CFAF 43 billion ( 3 percent of GDP). Mining companies contribute to social infrastructure, by building roads, bridges, wells, schools, hospitals, and dispensaries, and contribute to villages in various ways. However, in the absence of more detailed information, the impact on the economy cannot be adequately assessed.

\section{H. Conclusion}

26. The adoption of an internationally competitive Mining Code in 1991 served to foster the rapid development of industrial gold mining in Mali. Indeed, gold has become Mali's second principal export commodity, substantially increased the mining industry"s contribution to the public finances, and, to a more limited extent, fostered modern sector employment.

27. The development of industrial gold mining has also served to diversify the fragile Malian economy somewhat and to increase private sector activity. Nevertheless, the concentration in exports on the three principal commodities of cotton, gold, and livestock remains extremely high at over 94 percent in 1999. In this regard, it must be borne in mind that gold is a nonrenewable resource and that, when endowments are exhausted, other activities must replace goid mining, so as to avert a costly and difficult adjustment. With the success of gold mining serving as an example, the Malian government, therefore, continues to liberalize other important sectors of the economy.

28. On a global scale, Mali still ranks as a relatively small producer. The existence of alternative gold deposits in other countries, in combination with the mobility of foreign mining companies, underscores the importance of majntaining competitive mining legislation and ensuring a stable business regulation and taxation regime. Mali has sufficient gold reserves to remain a gold exporter for several decades to come, and it would do well to continue to implement sound and stable mining policies. 
$-19-$

Table 1. Mali: Gross Domestic Product at Constant ]987 Prices, 1994-99 ${ }^{1}$

\begin{tabular}{|c|c|c|c|c|c|c|}
\hline & 1994 & 1995 & 1996 & 1997 & 1998 & $\begin{array}{r}1999 \\
\text { Est. }\end{array}$ \\
\hline$\cdot$ & \multicolumn{6}{|c|}{ (In billiots of $C F A$ francs) } \\
\hline Primary sector & 328.2 & 350.2 & 344.0 & 359.7 & 361.9 & 393.1 \\
\hline Food crops & 142.9 & 159.9 & 142.3 & 150.7 & 143.2 & 171.7 \\
\hline Industrial creps ${ }^{2}$ & 44.4 & 46.6 & 59.4 & 64.0 & 73.3 & 73.4 \\
\hline Livestock & 93.3 & 939 & 91.4 & 93.0 & 92.1 & 93.3 \\
\hline Fishing & 9.8 & 10.0 & 10.1 & 10.2 & 10.4 & 10.5 \\
\hline Forestry & 37.8 & 39.8 & 40.8 & 41.8 & 43.0 & 44.2 \\
\hline Secondary sector & 114.6 & 116.3 & 124.0 & 151.6 & 162.2 & 165.3 \\
\hline Industry & 47.8 & 44.9 & 46.7 & 51.8 & 52.1 & 50.7 \\
\hline Mining & 14.9 & 14.7 & 15.8 & 38.0 & 46.4 & 51.4 \\
\hline Fandicrafts & 17.3 & 19.2 & 20.7 & 20.4 & 21.0 & 20.9 \\
\hline Construction and public works & 35.5 & 37.6 & 40.9 & 41.4 & 42.7 & 42.4 \\
\hline Teriary sector & 238.4 & 239.2 & 259.7 & 264.9 & 277.5 & 286.8 \\
\hline Transportation & 32.4 & 38.0 & 40.9 & 42.6 & 46.2 & 48.1 \\
\hline Trade & 116.8 & 104.6 & 118.3 & $\$ 21.8$ & 127.8 & 133.7 \\
\hline Public atministration & 38.0 & 50.4 & 52.4 & 52.5 & 53.6 & 53.7 \\
\hline Other services & 51.2 & 46.2 & 48.1 & 48.0 & 49.9 & 51.4 \\
\hline GDP (at factor cost) & 681.3 & 705.7 & 727.7 & 776.2 & 801.6 & 845.3 \\
\hline Import taxes & 31.6 & 40.4 & 42.4 & 46.0 & 48.7 & 51.4 \\
\hline \multirow[t]{2}{*}{ GDP (at market prices) } & 712.9 & 746.3 & 770.1 & 822.2 & 850.3 & 896.7 \\
\hline & \multicolumn{6}{|c|}{ (Arnial percentage change, unless otherwise indicated) } \\
\hline Primary sector & 1.5 & 6.7 & -1.8 & 4.6 & 0.6 & 8.6 \\
\hline Food crops & 20.1 & 11.9 & -11.0 & 5.9 & -5.0 & 19.9 \\
\hline industrial crops ${ }^{2}$ & -16.1 & 4.9 & 27.5 & 7.7 & 34.5 & 0.1 \\
\hline Livestack & 6.0 & 0.7 & -2.7 & 1.8 & -1.0 & 1.3 \\
\hline Fishing & 5.0 & t.6 & 1.2 & 1.2 & 1.5 & 1.6 \\
\hline Forestry & 5.1 & 5.3 & 2.5 & 2.5 & 2.9 & 2.8 \\
\hline Secondary sector & 1.2 & 1.5 & 6.7 & 22.2 & 7.0 & 2.0 \\
\hline Industry & 2.1 & -6.2 & 4.0 & 110 & 0.5 & -2.6 \\
\hline Mining & -9.0 & 4.6 & 7.8 & 140.5 & 22.1 & 10.7 \\
\hline Hanticrafis & 2.8 & 11.3 & 7.6 & -1.4 & 2.9 & -0.5 \\
\hline Construction and public works & 3.6 & 5.8 & B.9 & 1.2 & 3.1 & -0.7 \\
\hline Tertiary sector & -2.8 & 0.3 & 8.6 & 2.0 & 4.8 & 3.4 \\
\hline Tramsportation & -2.6 & 17.2 & 7.6 & 4.2 & 8.5 & 4.0 \\
\hline Trade & -0.7 & -10.5 & 13.1 & 3.0 & 4.9 & 4.6 \\
\hline Public administration & -21.0 & 32.5 & 4.0 & 0.2 & 2.1 & 0.2 \\
\hline Other services & 10.7 & -9.7 & 4.2 & -0.3 & 4.0 & 3.0 \\
\hline GDP (at factor cost) & 2.6 & 3.6 & 3.1 & 6.7 & 3.3 & 5.5 \\
\hline Import taxes & -7.0 & 27.7 & 5.0 & 8.5 & 5.9 & 5.5 \\
\hline GDP (at market prices) & 2.2 & 4.7 & 3.2 & 6.8 & 3.4 & 5.5 \\
\hline \multicolumn{7}{|l|}{ Mernorandum jtems: } \\
\hline GDP deflator ${ }^{3}$ & 332 & 12.5 & 6.6 & 1.0 & 4.0 & -2.0 \\
\hline GDP at current market prices ${ }^{4}$ & 1028.7 & $1,231.0$ & $\mathrm{~J}, 339.8$ & $1,444.7$ & $1,553.8$ & $1,605.8$ \\
\hline
\end{tabular}

Sources: Malian authorities; and Fund slaff estimates.

\footnotetext{
${ }^{1}$ Data may not add up because of rơunding.

${ }^{2}$ Includes cotton, groundnuts, tobacco, thaito, vegetables, and others. Cotton accounted for approximately 85 percent of the total over the period 1993-98.

${ }^{3}$ Annual percentage change.

"In billions of CFA francs.
} 
Table 2. Mali: Origin and Use of Resources, 1994-99 I

\begin{tabular}{|c|c|c|c|c|c|c|}
\hline & 1994 & 1995 & 1996 & 1997 & 1998 & $\begin{array}{l}1999 \\
\text { Est. }\end{array}$ \\
\hline & \multicolumn{6}{|c|}{ (In tilliots of CFA francs) } \\
\hline Gross dornestic product & $4,028.7$ & $1,23 t .0$ & $1,739.8$ & $1,444.7$ & $1,553.8$ & $1,605.8$ \\
\hline Consumpion & 955.6 & $1,135.3$ & $1,237,1$ & $1,294.9$ & $1,380.3$ & $1,443.3$ \\
\hline Goverament & 124,4 & 135.7 & 136.2 & 171.1 & 176.2 & 202.3 \\
\hline Nangovernment & 831.2 & 999.6 & $i_{5} 1009$ & $1,123,8$ & $1,204.1$ & $1,241.0$ \\
\hline Donestic savings & 73.1 & 95.7 & 102.7 & 149.8 & 173.5 & 162.5 \\
\hline Govermuent & 14.5 & 41.6 & 48.8 & 54.7 & 55.5 & 45.4 \\
\hline Nangovernmeat & 58.6 & 54.1 & 53.9 & 95.1 & I18.0 & 117.1 \\
\hline Invesument & 267.5 & 281.9 & 306.8 & 297.6 & 324.8 & $340: 4$ \\
\hline Government & 133.8 & 115.9 & 123.1 & 118.9 & 147.1 & 151.4 \\
\hline Nongavemment & 133.7 & 166.0 & 183.8 & 178.7 & 177.7 & 189.1 \\
\hline $\begin{array}{l}\text { Expons of goods and noufactor } \\
\text { services }\end{array}$ & 225.1 & 259.9 & 268.4 & 377.3 & 380.2 & 400.4 \\
\hline \multirow[t]{2}{*}{$\begin{array}{l}\text { Iroports of goods and nonfactor } \\
\text { services }\end{array}$} & -419.5 & .446 .1 & -472.5 & -525.1 & .531 .5 & -578.3 \\
\hline & \multicolumn{6}{|c|}{ (In percent of GDP) } \\
\hline Gross donnestic product & 100.0 & 100.0 & 100.0 & 100,0 & 100.0 & 100.0 \\
\hline Consumpion & 92.9 & 92.2 & 92.3 & 89.6 & 88.9 & 89.9 \\
\hline Govermmeans & 12.1 & 11,0 & 10.2 & 11.8 & 11,3 & 12.6 \\
\hline Nangswengmast & 80.8 & 81.2 & 82.2 & 778 & 77.5 & $\pi .3$ \\
\hline Domestic savings & 3.1 & 7.8 & 7.3 & 10.4 & 11.2 & 10.1 \\
\hline Government & 1.4 & 3.4 & 3.6 & 3.8 & 3.6 & 2.3 \\
\hline Nos-govemment & 5.7 & 4.4 & 4.0 & 8.6 & 7.6 & 7.3 \\
\hline Investment & 26.0 & 22.9 & 22.9 & 20.6 & 20.9 & 21.2 \\
\hline Government & 13.0 & 9.4 & 9.2 & 8.2 & 9.5 & 9.4 \\
\hline Nơngoverment & 13.0 & 13.5 & 13.7 & 12.4 & 11.4 & 11.8 \\
\hline Resource gap & -189 & -15.1 & -15.2 & -10.2 & -9.7 & -11.1 \\
\hline \multicolumn{7}{|l|}{ Exports of gonds and nonfactor } \\
\hline \multicolumn{7}{|l|}{ Impors of grods and nonfactor } \\
\hline servioes & 40.8 & -36.2 & -35.3 & -36.3 & -34.2 & -36.0 \\
\hline \multicolumn{7}{|l|}{ Memorandwn irems: } \\
\hline & \multicolumn{6}{|c|}{ (In billions of CFA francs) } \\
\hline Current account deficit (excl, off. transfers) & -39.2 & -92.1 & -66.0 & -39.1 & -46.7 & -77.0 \\
\hline Of which: private transfers & 47.1 & 47.8 & 46.0 & 42.6 & 40.7 & 42.4 \\
\hline Official trantfees & 134.4 & 111.4 & 124.1 & 96.3 & 100.8 & 92.9 \\
\hline Net factor inecome & -26.4 & -32.5 & -25.5 & -31.0 & -30.7 & -26.9 \\
\hline \multirow[t]{2}{*}{ National savings } & 93.8 & 111.0 & 16.7 & 161.4 & 177.3 & 170.5 \\
\hline & \multicolumn{6}{|c|}{ (In percent of GDP) } \\
\hline Curtent gocount deficit (incl. off. mansfers) & -3.8 & -6.7 & -4.9 & -2.7 & -3.0 & -4.8 \\
\hline Of which: private transfers & 4.6 & 3.9 & 3.4 & 2.9 & 2.6 & 26 \\
\hline Official trapsters & 13.1 & 9.0 & 9.3 & 6.7 & 6.5 & 5.8 \\
\hline Nee factor misome & -2.6 & -2.6 & -1.9 & -2.1 & -2.0 & -4.7 \\
\hline National savimgs & 9.1 & 9.0 & 8.7 & 11.2 & 11.4 & 10.6 \\
\hline
\end{tabular}

Sources: Malin authorities: and Fund staff estimates.

'Data may not add up because of rounding. 
Table 3. Mali: Agricultural Production and Average Producer Prices, 1994/95-1998/99 ${ }^{1}$

\section{$\begin{array}{lllll}1994 / 95 & 1995 / 96 & 1996 / 97 & 1997 / 98 & 1998 / 99\end{array}$}

(In thousands of metric tons)

Production (gross)

Cotton

Groundnuts

Millet

Sorghum

Maize

Paddy rice

Average producer prices

Cotton $^{23}$

Floor price

Rebate from profit sharing

Groundnuts

Millet

Sorghum

Maize

Paddy rice
293

215

898

746

322

469

130

125

5

162

51

59

55

87

(In CFA francs per kilogram)

$\begin{array}{ll}452 & 523 \\ 134 & 143\end{array}$

$541 \quad 503 \quad 539$

710

294

311

354

463

627

511

634

$\begin{array}{rrrrr}30 & 155 & 155 & 170 & 185 \\ 5 & 125 & 125 & 125 & 145 \\ 5 & 30 & 30 & 30 & 40\end{array}$

\begin{tabular}{rrrrr}
2 & 180 & 249 & 150 & 155 \\
1 & 97 & 77 & 105 & 71 \\
9 & 99 & 77 & 98 & 86 \\
5 & 83 & 69 & 80 & 90 \\
7 & 118 & 105 & 123 & 115 \\
\hline
\end{tabular}

Sources: Malian authorities; and Fund staff estimates.

1 The crop year is April/March; the marketing year is November/October.

2 Except for cotton, the marketing of agricultural products by official agencies was discontinued in 1995.

3 Actual price for first quality cotton, including rebate based on profit of the cotton company (CMDT). 
Table 4. Mali: Cereals - Cultivated Area and Rainfall, 1994/95-1998/99 ${ }^{1}$

\begin{tabular}{|c|c|c|c|c|c|c|}
\hline & $\begin{array}{l}1960-90 \\
\text { Average }\end{array}$ & $1994 / 95$ & $1995 / 96$ & $1996 / 97$ & $1997 / 98$ & $\begin{array}{r}1998 / 99 \\
\text { Est. }\end{array}$ \\
\hline & \multicolumn{6}{|c|}{ (Thousands of hectares, unless otherwise indicated) } \\
\hline \multicolumn{7}{|l|}{ Cultivated area } \\
\hline Millet/sorghum & 1,423 & 2,380 & 2,137 & 1,476 & 1,451 & 1,527 \\
\hline Deviation $^{2}$ & & 67 & 50 & 4 & 2 & 7 \\
\hline Maize & 97 & 284 & 205 & 181 & 197 & 239 \\
\hline Deviation $^{2}$ & & 193 & 111 & 87 & 103 & 146 \\
\hline Paddy rice & 159 & 284 & 303 & 324 & 326 & 326 \\
\hline Deviation $^{2}$ & & 79 & 91 & 104 & 105 & 105 \\
\hline \multicolumn{7}{|c|}{ (In millimeters, unless otherwise indicated; April-October) ${ }^{3}$} \\
\hline Rainfall & & & & & & \\
\hline Millet/sorghum & 720 & 593 & 525 & 579 & 586 & 602 \\
\hline Deviation $^{2}$ & & -18 & -27 & -20 & -19 & -16 \\
\hline Maize & 880 & 1,208 & 1,033 & 882 & 938 & 1,412 \\
\hline Deviation $^{2}$ & & 37 & 17 & 0 & 7 & 60 \\
\hline Paddy rice & 557 & 386 & 399 & 515 & 328 & 453 \\
\hline Deviation $^{2}$ & & -31 & -28 & -8 & -41 & -19 \\
\hline
\end{tabular}

Sources: Malian authorities; and Fund staff estimates.

${ }^{1}$ The crop year is April/March; the marketing year is November/October.

${ }^{2}$ Deviation in percent from the annual average of the $1960-90$ period.

${ }^{3}$ Rainfall is measured for the specific area where each cereal is grown. 
Table 5. Mali: Quarterly Retail Prices for Cereals, 1994-1999 (In CFA francs per kilogram)

\begin{tabular}{|c|c|c|c|}
\hline & Millet'Sorghum & Maize & Rice (RM 40) \\
\hline \multicolumn{4}{|c|}{ Annwal averages } \\
\hline 1994 & 77.3 & 75.5 & 218.8 \\
\hline 1995 & 109.6 & 114.8 & 258.8 \\
\hline 1996 & 151.3 & 139.3 & 266.5 \\
\hline 1997 & 121.3 & 121.5 & 244.8 \\
\hline 1998 & 149.0 & 144.8 & 259.0 \\
\hline 1999 & 132.7 & 124.7 & 255.9 \\
\hline \multicolumn{4}{|l|}{1994} \\
\hline I & 76.0 & 72.0 & 195,0 \\
\hline II & 76.5 & 74.0 & 206.0 \\
\hline III & 78.0 & 79.0 & 234.0 \\
\hline IV & 78.5 & 77.0 & 240.0 \\
\hline \multicolumn{4}{|l|}{1995} \\
\hline I & 88.0 & 98.0 & 227.0 \\
\hline II & 91.5 & 112.0 & 264.0 \\
\hline III & 132.0 & 127.0 & 274.0 \\
\hline IV & 127.0 & 122.0 & 270.0 \\
\hline \multicolumn{4}{|l|}{1996} \\
\hline I & 114.0 & 114.0 & 254.0 \\
\hline II & 151.0 & 144.0 & 277.0 \\
\hline III & 184.0 & 172.0 & 285.0 \\
\hline IV & 156.0 & 127.0 & 250.0 \\
\hline \multicolumn{4}{|l|}{1997} \\
\hline I & 127.0 & 123.0 & 248.0 \\
\hline II & 125.0 & 124.0 & 241.0 \\
\hline III & 118.0 & 125.0 & 249.0 \\
\hline IV & 115.0 & 114.0 & 241.0 \\
\hline \multicolumn{4}{|l|}{$1998^{\prime}$} \\
\hline I & 113.0 & 117,0 & 227.0 \\
\hline II & 151.0 & 143.0 & 250.0 \\
\hline III & 177,0 & 178.0 & 291.0 \\
\hline IV & 155.0 & 141.0 & 268.0 \\
\hline \multicolumn{4}{|c|}{$1999^{2}$} \\
\hline I & 130.0 & 126.0 & 231.0 \\
\hline II & 141.0 & 129.0 & 262.0 \\
\hline โII & 140.0 & 126.0 & 274.0 \\
\hline IV & 119.8 & 117.7 & 256.7 \\
\hline
\end{tabular}

Sources: Malian authorities; and Fund staff estimates.

' Free market prices represent the average of prices prevailing in 13 Bamako markets.

${ }^{2}$ Estimates. 
Table 6. Mali: Office du Niger - Indicators of Activity, 1994/95-1998/99 ${ }^{1}$

\begin{tabular}{lcc}
\hline & $\begin{array}{c}\text { Area Cultivated } \\
\text { with Rice } \\
\text { (In hectares) }\end{array}$ & $\begin{array}{c}\text { Paddy Rice } \\
\text { Harvested } \\
\text { (In metric tons) }\end{array}$ \\
\hline $1994 / 95$ & 46,740 & 209,979 \\
$1995 / 96$ & 50,911 & 238,803 \\
$1996 / 97$ & 54,102 & 267,980 \\
$1997 / 98$ & 53,876 & 277,182 \\
$1998 / 99$ & 50,026 & 295,000 \\
\hline
\end{tabular}

Source: Malian authorities.

${ }^{1}$ The crop year is April/March. 
Table 7. Mali: Implementation of the Public Investment Program, 1994-99

(In billions of CFA francs)

\begin{tabular}{|c|c|c|c|c|c|c|}
\hline & 1994 & 1995 & 1996 & 1997 & 1998 & $\begin{array}{r}1999 \\
\text { Est. }\end{array}$ \\
\hline Rural development & 44.0 & 53.2 & 57.8 & 63.9 & 50.8 & 61.4 \\
\hline Agriculture & 35.8 & 43.1 & 45.8 & 53.8 & 39.5 & 53.8 \\
\hline Livestock & 3.5 & 4.3 & 5.0 & 5.3 & 5.1 & 4.7 \\
\hline Fisheries & 0.0 & 0.1 & 0.1 & 0.0 & 0.0 & 0.0 \\
\hline Forestry & 4.7 & 5.7 & 6.9 & 4.8 & 6.2 & 2.9 \\
\hline Secondary sector & 23.1 & 21.0 & 26.0 & 39.2 & 62.3 & 45.3 \\
\hline Mines and geology & 1.1 & 0.5 & 1.2 & 1.2 & 0.8 & 1.3 \\
\hline Water & 14.5 & 13.4 & 16.9 & 18.2 & 20.2 & 16.8 \\
\hline Energy & 7.3 & 6.9 & 7.6 & 18.7 & 39.8 & 25.7 \\
\hline Industry and handicrafts & 0.2 & 0.2 & 0.3 & 1.1 & 1.5 & 1.5 \\
\hline Tourism & 0.0 & 0.0 & 0.0 & 0.0 & 0.0 & 0.0 \\
\hline Infrastructure & 20.7 & 24.2 & 32.3 & 39.9 & 41.2 & 62.2 \\
\hline Roads & 8.9 & 13.1 & 21.7 & 23.5 & 25.7 & 24.6 \\
\hline Railroads & 1.6 & 0.1 & 0.0 & 0.0 & 1.7 & 7.6 \\
\hline Air transport and metereology & 0.7 & 0.6 & 0.2 & 0.6 & 1.0 & 4.2 \\
\hline Post and telecommunications & 1.9 & 3.8 & 3.4 & 4.4 & 2.4 & 3.7 \\
\hline Surveying and mapping & 0.0 & 0.1 & 0.2 & 0.2 & 0.2 & 0.2 \\
\hline Buildings and equipment & 5.6 & 4.6 & 5.2 & 5.5 & 5.4 & 7.8 \\
\hline Urban development and housing & 2.0 & 1.7 & 1.2 & 5.3 & 4.2 & 13.5 \\
\hline Transport and storage & 0.0 & 0.2 & 0.4 & 0.4 & 0.6 & 0.6 \\
\hline Human resources & 33.8 & 39.3 & 45.8 & 33.5 & 42.8 & 47.7 \\
\hline Employment & 4.2 & 6.7 & 7.1 & 2.3 & 1.0 & 0.9 \\
\hline Education & 7.6 & 9.9 & 9.4 & 10.4 & 15.8 & 16.0 \\
\hline Sports, arts, and culture & 0.4 & 0.4 & 0.4 & 0.5 & 3.9 & 5.7 \\
\hline Health & 11.0 & 11.8 & 13.7 & 9.9 & 8.0 & 11.7 \\
\hline Information & 1.0 & 0.6 & 1.1 & 1.5 & 4.3 & 3.2 \\
\hline Administration & 9.6 & 9.9 & 14.1 & 8.9 & 9.8 & 10.2 \\
\hline Total & 121.6 & 137.7 & 161.9 & 176.5 & 197.1 & 216.6 \\
\hline
\end{tabular}

Source: Malian authorities.

${ }^{1}$ Data may not add up because of rounding. 
Table 8. Mali: Investment Budget for 1994-99 and

Existing Commitments for Public Investment, 2000-02 $2^{12}$

(In billions of CFA francs)

\begin{tabular}{|c|c|c|c|c|c|c|c|}
\hline & 1994 & 1995 & 1996 & 1997 & 1998 & 1999 & $\begin{array}{l}2000-02 \\
\text { Existing } \\
\text { Commitrnents }\end{array}$ \\
\hline Rusal development & 56.7 & 67.1 & 65.9 & 68.0 & 60.6 & 64.8 & 199.4 \\
\hline Agriculture & 41.1 & 53.5 & 52.8 & 54.0 & 49.3 & 55.1 & 184.7 \\
\hline Livestoek & 8.8 & 7.4 & 7.7 & 8.0 & 5.9 & 7.2 & 8.1 \\
\hline Fisheries & 0.0 & 0.1 & 0.1 & 0.0 & 0.0 & 00 & 2.2 \\
\hline Forestry & 6.8 & 6.1 & 5.3 & 6.0 & 5.4 & 2.4 & 4.6 \\
\hline Secondary sector & 21.7 & 27.4 & 27.4 & 29.4 & 55.0 & 51.8 & 83.9 \\
\hline Mines & 1.9 & 1.4 & 1.1 & 1.2 & 0.7 & 3.7 & 9.0 \\
\hline Water & 11.7 & 12.1 & 12.4 & 13.0 & 21.9 & 19.4 & 23.8 \\
\hline Energy & 8.0 & 13.6 & 13.6 & 15.0 & 31.9 & 26.7 & 45.1 \\
\hline Industry & 0.0 & 0.1 & 0.1 & 0.1 & 0.5 & 1.9 & 6.2 \\
\hline Tourism & 0.1 & 0.1 & 0.2 & 0.1 & 0.0 & 0.0 & 0.0 \\
\hline Infrastructure & 21.8 & 30.1 & 34.9 & 38.7 & 63.5 & 74,4 & 254.9 \\
\hline Roads & 10.8 & 20.5 & 26.2 & 28.0 & 28.1 & 31.9 & 149.1 \\
\hline Railraads & 1.8 & 2.6 & 4.9 & 6.2 & 6.4 & 6.3 & J4.5 \\
\hline Air transpont & 1.2 & 0.8 & 0.3 & 0.0 & 1.9 & 4.1 & 11.1 \\
\hline Post \& teleccmmtrnications & 2.6 & 2.8 & 1.5 & 2.0 & 5.6 & 6.4 & 15.2 \\
\hline Surveying & 0.1 & 0.1 & 0.0 & 0.0 & 0.2 & 0.2 & 1.1 \\
\hline Buildings & 3.5 & 2.7 & 1.7 & 2.0 & 5.4 & 7.8 & 14.3 \\
\hline Ustan development & 1.8 & 0.3 & 0.0 & 0.0 & 14.5 & 36.0 & 45.7 \\
\hline Transport and storage & 0.0 & 0.2 & 0.3 & 0.5 & 1.2 & 1.5 & 4.1 \\
\hline Hurnan resources & 36.1 & 42.7 & 36.0 & 42.2 & 40.1 & 43.9 & 156.0 \\
\hline Employment & 5.0 & 3.6 & 3.6 & 4.8 & 1.1 & 0.9 & 0.5 \\
\hline Education & 9.0 & 9.5 & 8.1 & 9.0 & 12.6 & 17.6 & 27.4 \\
\hline Sports, arts & 0.4 & 0.3 & 0.1 & 0.4 & 0.2 & 1.6 & 32.2 \\
\hline Elealth & 11.5 & 16.6 & 17.8 & 20.0 & 13.9 & 10.7 & 69.4 \\
\hline Information & 0.8 & 1.0 & 1.8 & 2.0 & 3.7 & 3.5 & 1.7 \\
\hline Administration & 9.4 & 11.5 & 4.6 & 6.0 & 8.5 & 9.4 & 25.0 \\
\hline Total & 136.3 & 167.3 & 164.2 & 178.3 & 219.3 & 234.9 & 694.0 \\
\hline Finamcing & 136.3 & 167.3 & 164.2 & 178.3 & 219.3 & 234.9 & 694.0 \\
\hline Extemal financing & 112.5 & 140.8 & 137.3 & 144.0 & 177.3 & 181.4 & 564.1 \\
\hline Laans & 56.0 & 74.2 & 67.5 & 78.0 & 92.7 & 98.3 & 326.0 \\
\hline Grants & 56.5 & 66.6 & 69.8 & 66.0 & 84.6 & 83.1 & 2380 \\
\hline Domestic financing & 23.8 & 26.5 & 26.9 & 34.3 & 42.0 & 53.5 & 129.7 \\
\hline Budget & 17.6 & 20.0 & 18.6 & 24.3 & 25.8 & 35]$. & 115.0 \\
\hline Self-financing & 5.0 & 5.2 & 6.5 & B.0 & 12.9 & 15.1 & 9,9 \\
\hline Other & 1.2 & 1.3 & 1.8 & 2.0 & 3.3 & 3.3 & 4.7 \\
\hline
\end{tabular}

Source: Malian suthorities.

'Data differ from those included in Table 15, Consolidated Government Operations, as an implennentation rate of less than 100 percent is assumed in the projections.

${ }^{2}$ Data may not add up becatse of rounding. 
Table 9. Mali: Livestock Exports, Slaughtering, and Herd Size, 1994-99

(In thousands of head, unless otherwise indicated)

\begin{tabular}{|c|c|c|c|c|c|c|c|c|c|c|c|c|}
\hline & \multicolumn{2}{|c|}{1994} & \multicolumn{2}{|c|}{1995} & \multicolumn{2}{|c|}{1996} & \multicolumn{2}{|c|}{1997} & \multicolumn{2}{|c|}{1998} & \multicolumn{2}{|c|}{$1999^{1}$} \\
\hline & Cattle & $\begin{array}{r}\text { Sheep } \\
\text { and } \\
\text { goats }\end{array}$ & $\overline{\text { Cattle }}$ & $\begin{array}{r}\text { Sheep } \\
\text { and } \\
\text { goats }\end{array}$ & $\overline{\text { Cattle }}$ & $\begin{array}{r}\text { Sheep } \\
\text { and } \\
\text { goats }\end{array}$ & Cattle & $\begin{array}{r}\text { Sheep } \\
\text { and } \\
\text { goats }\end{array}$ & $\overline{\text { Cattle }}$ & $\begin{array}{r}\text { Sheep } \\
\text { and } \\
\text { goats }\end{array}$ & Cattle & $\begin{array}{r}\text { Sheep } \\
\text { and } \\
\text { goats }\end{array}$ \\
\hline Exports & 440 & 738 & 418 & 925 & 216 & 537 & 396 & 775 & 263 & 575 & $\ldots$ & $\ldots$ \\
\hline Controlled & 176 & 340 & 107 & 426 & 65 & 215 & 119 & 349 & 79 & 230 & 129 & 323 \\
\hline Uncontrolled & 264 & 398 & 311 & 499 & 151 & 322 & 277 & 426 & 184 & 345 & $\ldots$ & $\ldots$ \\
\hline Slaughtering & 531 & 1,912 & 547 & 2,007 & 425 & 2,137 & 450 & 2,129 & 700 & 2,626 & $\ldots$ & $\ldots$ \\
\hline Controlled & 186 & 306 & 192 & 321 & 149 & 321 & 158 & 319 & 173 & 394 & 190 & 432 \\
\hline Uncontrolled & 345 & 1,606 & 355 & 1,686 & 276 & 1,816 & 292 & 1,810 & 527 & 2,232 & $\ldots$ & $\ldots$ \\
\hline $\begin{array}{l}\text { Estimated herd size } \\
\text { (end of period) }\end{array}$ & 5,542 & 12,552 & 5,708 & 13,179 & 5,882 & 13,809 & 6,058 & 14,500 & 6,240 & 15,224 & 6,426 & 15,985 \\
\hline Memorandum items: & & & & & & & & & & & & \\
\hline Net birth rate (in percent) & 1.1 & 3.2 & 1.1 & 3.6 & $\ldots$ & $\ldots$ & $\ldots$ & $\ldots$ & $\ldots$ & $\ldots$ & $\cdots$ & $\ldots$ \\
\hline Offtake rate (in percent) & 17.5 & 21.1 & 16.9 & 22.2 & 10.9 & 19.4 & 14.0 & 20.0 & 14.2 & 19.5 & $\ldots$ & $\ldots$ \\
\hline
\end{tabular}

Source: Malian authorities.

${ }^{1}$ Provisional data. 
Table 10. Mali: Index of Industrial Production, 1994-99

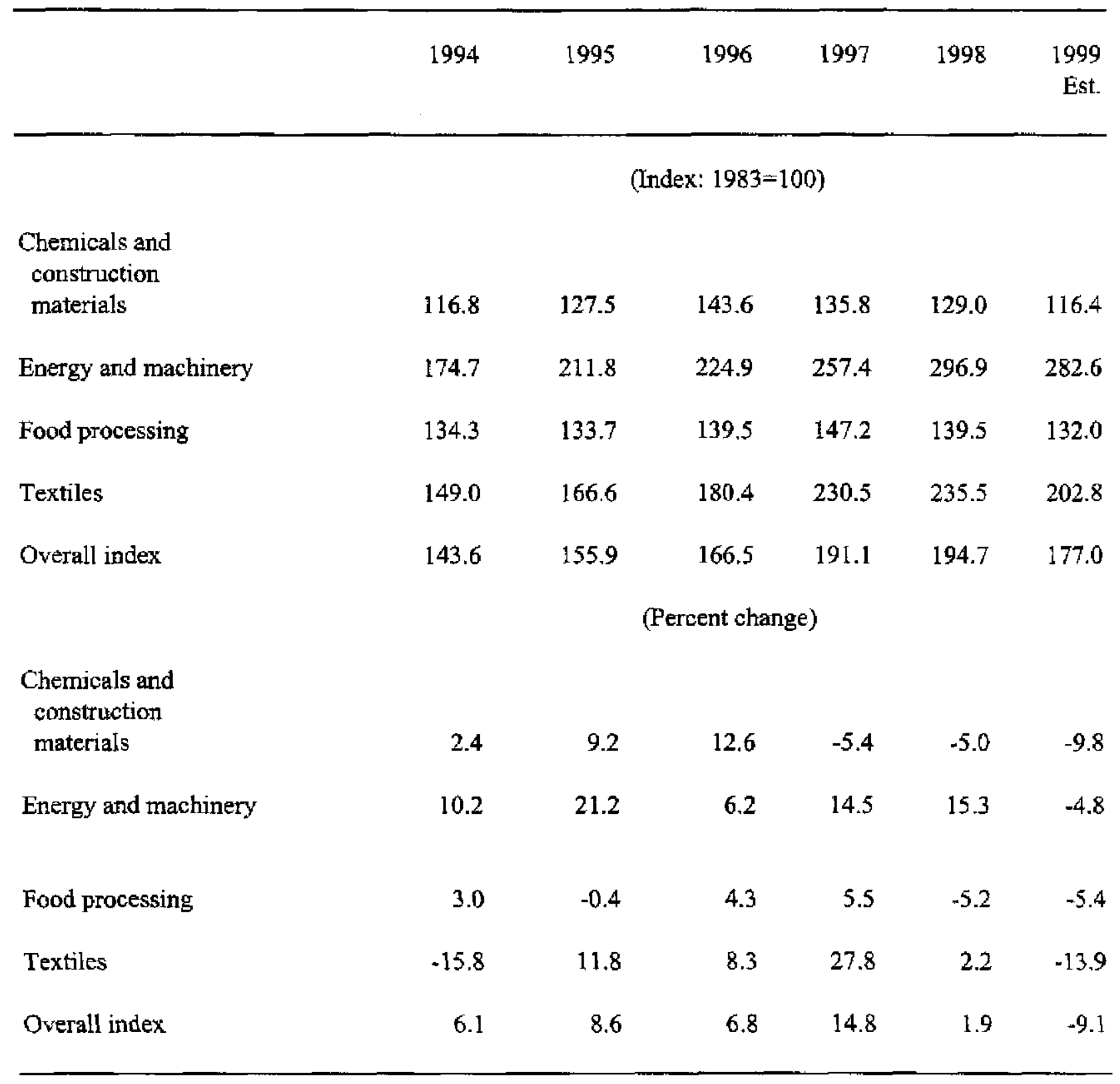

Source: Malian authorities. 
Table 11. Mali: Quarterly Index of Conşumer Prices in Bamako, 1998-2000

(ndex: 1996-100)

\begin{tabular}{|c|c|c|c|c|c|c|c|c|c|c|c|}
\hline & \multicolumn{5}{|c|}{1998} & \multicolumn{5}{|c|}{1999} & \multirow{2}{*}{$\frac{2000}{I}$} \\
\hline & I & II & III & IV & (Annual) & $\mathrm{I}$ & II & III & IV & (Annual) & \\
\hline Fond & 95.2 & 103.5 & 111.9 & 103.5 & 103.5 & 96.5 & 100.6 & 104.9 & 98.9 & 100.2 & 92.7 \\
\hline Clothing & 104.1 & 105.0 & 105.1 & 104.7 & 104.7 & 108.9 & 108.1 & 108.4 & 109.1 & 108.6 & 103.3 \\
\hline Mousing, water, and energy & 97.7 & 99.4 & 98.3 & 98.5 & 98.5 & 98.0 & 98.8 & 106.3 & 107.3 & 102.6 & 103.7 \\
\hline Furniture and household articles & 101.7 & 101.7 & 103.0 & 102.1 & 102.1 & 104.9 & 105 & 105.1 & 105.1 & 105.0 & 108.0 \\
\hline Health & 101.9 & 102.8 & 102.6 & 102.4 & 102.4 & 109.6 & 109.8 & 109.5 & 110.0 & 109.7 & 102.8 \\
\hline Transport and communications & 99.9 & 100.0 & 100.0 & 100.0 & 100.0 & 99.9 & 100.0 & 100.4 & 99.9 & 100.1 & 100.8 \\
\hline Leisure and entertainment & 102.6 & 102.8 & 102.8 & 102.7 & 102.7 & 100.7 & 100.3 & 100.4 & 100.8 & 100.6 & 99.1 \\
\hline Other goods and services & 114.3 & 113.8 & 114.3 & 114.1 & 114.1 & 110.8 & 110.9 & 111.6 & 112.4 & 111.4 & 114.0 \\
\hline Total $^{2}$ & 98.6 & 103.0 & 107.2 & 104.4 & 103.3 & 99.7 & 101.9 & 105.0 & 102,0 & 102.1 & 98.6 \\
\hline
\end{tabular}

Source: Mylian authoritjes,

' Harmonized consumer price index for West Affican Fconomic and Monetary Union (WAEMU) countries (1996=100), introduced beginning January 1, 1998 .

${ }^{2}$ Weighted totak. 
Table 12. Mali: Minimum Wages and Salgries in the Public Sector, 1994-99 (In CFA francs per month)

\begin{tabular}{|c|c|c|c|c|c|c|c|}
\hline & \multicolumn{2}{|c|}{1994} & \multirow[t]{2}{*}{1995} & \multirow[t]{2}{*}{1996} & \multirow[t]{2}{*}{1997} & \multirow[t]{2}{*}{1998} & \multirow{2}{*}{$\begin{array}{r}1999 \\
\text { Est. }\end{array}$} \\
\hline & April & $\overline{\text { Oct. }}$ & & & & & \\
\hline \multicolumn{8}{|l|}{ Contractual workers } \\
\hline \multicolumn{7}{|l|}{ Minimum wage for unskilled } & 23,744 \\
\hline Basic wage & 10,220 & 11,265 & 11,265 & 11,863 & 12,456 & 13,078 & 13,994 \\
\hline Special allowance & 1,000 & $\zeta, 000$ & 1,000 & 1,000 & 1,000 & 1,000 & 1,000 \\
\hline Cost of living allowance & 2,250 & 2,250 & 2,250 & 2,250 & 2,250 & 2,250 & 2,250 \\
\hline Solidarity allowance & 6,500 & 6,500 & 6,500 & 6,500 & 6,500 & 6,500 & 6,500 \\
\hline \multicolumn{8}{|l|}{ Minimum wage for unskilled } \\
\hline workers outside agriculture (SMIG) & 20,350 & 20,965 & 20,965 & 21,638 & 22,228 & 22,848 & 23,760 \\
\hline Basic wage & 10,523 & 11,138 & 11,138 & 11,811 & 12,401 & 13,021 & 13,933 \\
\hline Special allowance & 1,000 & 1,000 & 1,000 & 1,000 & 1,000 & 1,000 & 1,000 \\
\hline Cost of living allowance & 2,250 & 2,250 & 2,250 & 2,250 & 2,250 & 2,250 & 2,250 \\
\hline Adjustment of March 1980 & 77 & 77 & 77 & 77 & 77 & 77 & 77 \\
\hline Solidarity allowance & 6,500 & 6,500 & 6,500 & 6,500 & 6,500 & 6,500 & 6,500 \\
\hline \multicolumn{8}{|l|}{ Government employees } \\
\hline Grade 100 & 32,600 & 33,800 & 33,800 & 34,040 & 34,040 & 35,340 & 37,254 \\
\hline Base salary & 23,600 & 24,800 & 24,800 & 26,040 & 26,040 & 27,340 & 29,254 \\
\hline Housing allowance & 1,500 & 1,500 & 1,500 & 1,500 & 1,500 & 1,500 & 1,500 \\
\hline Special allowance & 1,000 & 1,000 & 1,000 & 0 & 0 & 0 & 0 \\
\hline Solidarity allowance & 6,500 & 6,500 & 6,500 & 6,500 & 6,500 & 6,500 & 6,500 \\
\hline Grade 316 & 78,076 & 81,868 & 81,868 & 85,786 & 85,786 & 89,894 & 95,942 \\
\hline Base salary & 74,576 & 78,368 & 78,368 & 82,286 & 82,286 & 86,394 & 92,442 \\
\hline Housing allowance & 1,500 & 1,500 & 1,500 & 1,500 & 1,500 & 1,500 & 1,500 \\
\hline Solidarity allowance & 2,000 & 2,000 & 2,000 & 2,000 & 2,000 & 2,000 & 2,000 \\
\hline Grade 650 & 156,900 & 164,700 & 164,700 & 172,760 & 172,760 & 181,210 & 193,650 \\
\hline Base salary & 153,400 & 161,200 & 161,200 & 169,260 & 169,260 & 177,710 & 190,150 \\
\hline Housing allowance & 1,500 & 1,500 & 1,500 & 1,500 & 1,500 & 1,500 & 1,500 \\
\hline Solidarity allowance & 2,000 & 2,000 & 2,000 & 2,000 & 2,000 & 2,000 & 2,000 \\
\hline
\end{tabular}

Source: Malian authorities. 
Table 13. Mali: Employment in the Central and

Regional Governments and the Public Enterprise Sector, 1994-99

(Numbers of employees)

\begin{tabular}{|c|c|c|c|c|c|c|}
\hline & 1994 & 1995 & 1996 & 1997 & 1998 & $\begin{array}{r}1999 \\
\text { Est. }\end{array}$ \\
\hline Central and regional governments & 32,719 & 32,527 & 36,138 & 37,360 & 37,841 & 38,750 \\
\hline Civil servants & 29,141 & 29,067 & 31,961 & 33,235 & 33,534 & 34,226 \\
\hline Contractual employees and other & 3,578 & 3,460 & 4,177 & 4,125 & 4,307 & 4,524 \\
\hline Public enterprises ${ }^{t}$ & 7,699 & 7,041 & 6,228 & 2,849 & 2,897 & . \\
\hline
\end{tabular}

Source: Malian authorities.

1 The public enterprises included here are: Compagnie Malienne de Navigation (COMANAV), Energie du Mati (EDM), Entreprise Maliente de Maintenance (EMAMA), Office d'Exploitation des Ressources Hydrauliques du Haut Niger (OERHN), Office National des Postes (ONP), Office de Radio et Télévision (ORT), Société d'Equipement du Mali (SEMA), Société Nationale des Tabacs et Allumettes du Mali (SONATAM), and Usine Malienne de Produits Pharmaceutiques (UMPP). 
Table 14. Mali: Operating Results of Major Public Enterprises, 1994-99 '

(In millions of CFA francs; end of period)

\begin{tabular}{|c|c|c|c|c|c|c|c|}
\hline Enterprise & Activity & 1994 & 1995 & 1996 & 1997 & 1998 & $\begin{array}{r}1999 \\
\text { Est } \\
\end{array}$ \\
\hline EDM & Electricity & 710.2 & $2,012.7$ & $-1,882.0$ & $-1,895.0$ & 1769.0 & $\ldots^{2}$ \\
\hline SONATAM & Tobacco & 79.5 & 75.4 & 59.0 & -1872.5 & -3529.4 & $\ldots^{2}$ \\
\hline OERHN & Dam on the Niget River & -95.1 & $\ldots^{2}$ &.$^{3}$ & $\ldots^{3}$ & $\ldots^{3}$ & $\ldots^{2}$ \\
\hline PPM & Phamaceutical sales & -85.3 & -95.4 & 65.9 & 103.4 & 100.5 & $\ldots{ }^{2}$ \\
\hline SEMA & Public works & 85.2 & 28.5 & 124.1 & 308.1 & $\ldots^{4}$ & $\ldots^{2}$ \\
\hline EMAMA & Maintenance & -51.3 & -37.0 & 1.0 & $\ldots{ }^{2}$ & $\ldots{ }^{4}$ & $\ldots{ }^{2}$ \\
\hline ITEMA & Textiles & $-4,093.1$ & 58.0 & -426.7 & $\ldots{ }^{2}$ & $\ldots^{2}$ & $\ldots{ }^{2}$ \\
\hline COMATEX & Textiles & -13.5 & 735.2 & 982.6 & $1,267.6$ & $1,480.0$ & $\ldots^{2}$ \\
\hline COMANAV & Inland water transpont & -404.5 & -196.3 & 59.0 & 220.8 & -197.8 & $\ldots{ }^{2}$ \\
\hline RCFM & Railways & 44.5 & 325.9 & 249.0 & 221.0 & $\ldots{ }^{2}$ & $\ldots^{2}$ \\
\hline ONP & Postal services & -158.1 & -357.8 & -121.1 & -33.6 & -249.1 & $\ldots^{2}$ \\
\hline UMPP & Pharmaceutical products & 495.4 & 236.5 & 98.2 & 19.7 & -493.1 & $\ldots^{2}$ \\
\hline ORT & Hotels & 2.1 & 15.5 & 1.7 & 328.3 & $\ldots^{3}$ & $\ldots{ }^{2}$ \\
\hline SOTELMA & Telecommunications Services & $2,844.7$ & $3,570.0$ & $10,228.0$ & $11,158.0$ & $8,852.3$ & $\ldots^{2}$ \\
\hline
\end{tabular}

Source: Malian authorities.

${ }^{\prime}$ A list of acronyms of the enterprises is provided in Appendix 11.

2 Data not available.

${ }^{3}$ Activity interrupted.

${ }^{4}$ Enterprise privatized. 
Table 15. Malj: Consolidated Governmem Operations, 1994-99'

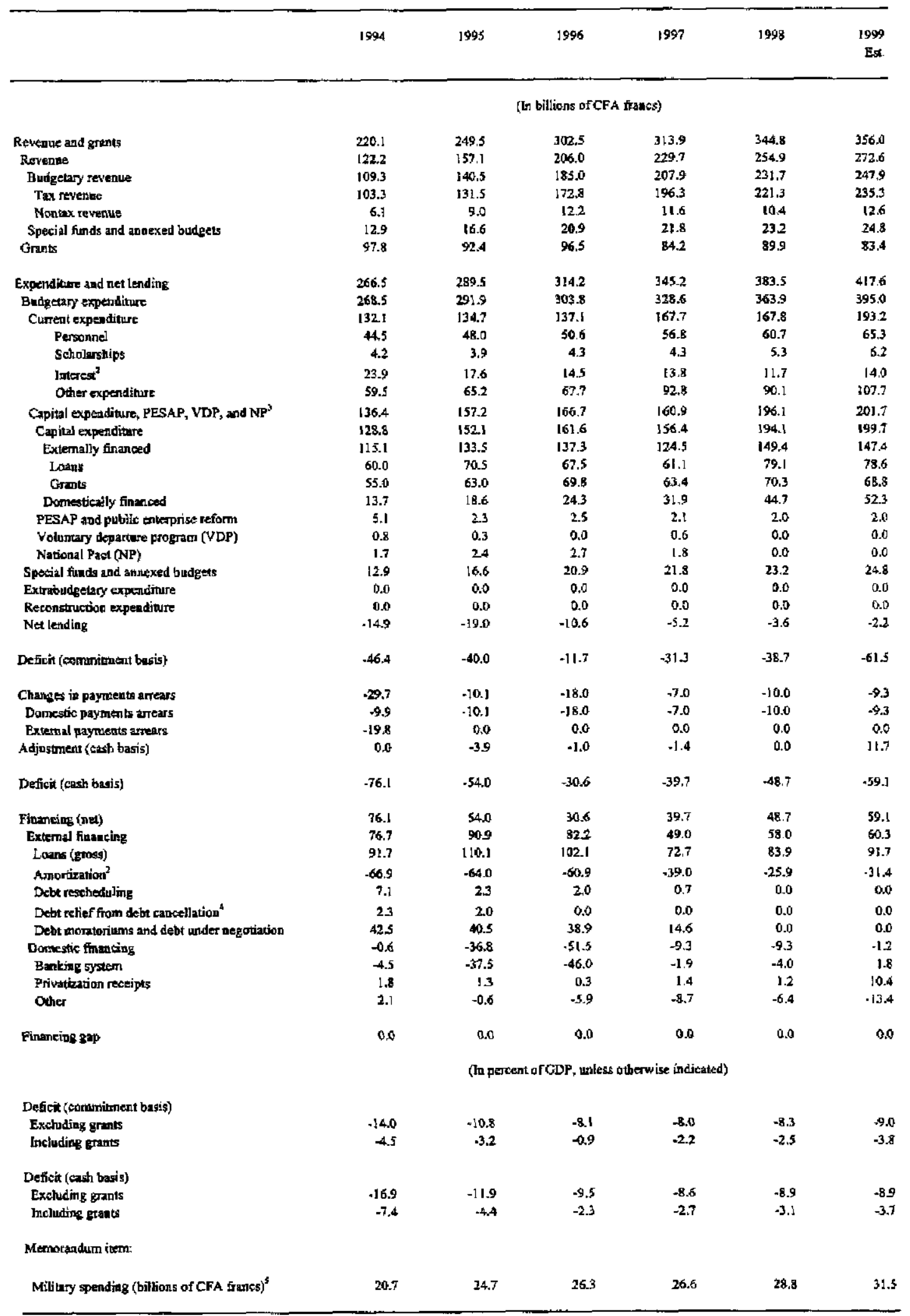

Sources: Malian anthorities; and Fund staff estimates.

'Data may not add up because of counding.

2Scheduled; after debl ancellation obtained through 1993.

${ }^{3}$ PESAP. Public Enterprise Sector Adjustnent Program, financed by the World Bank and cofioanciers.

"Based on the cancelbrion of ofticis] development assistance (ODA) debt obtrined in 1994.

${ }^{5}$ Expenciture by the Ministry of National Delense. 


$$
-34=
$$

Table 16. Mali: Govermment Revenute, 1994-99'

(In billions of CFA francs)

\begin{tabular}{|c|c|c|c|c|c|c|}
\hline & 1994 & 1995 & 1996 & 1997 & 1998 & $\begin{array}{r}1999 \\
\text { Est. }\end{array}$ \\
\hline Taxes on net income and profits & 16.2 & 26.6 & 34.5 & 37.8 & 42.8 & 34.6 \\
\hline Enterprises & 5.7 & 10.8 & 19.7 & 20.9 & 25.0 & 17.4 \\
\hline Public & 1.3 & 0.8 & 0.1 & 2.9 & 0.6 & 0.4 \\
\hline Private & 4.4 & 10.0 & 19.6 & 18.0 & 24.4 & 17.0 \\
\hline Inójviduals & 8.6 & 14.2 & 12.6 & 14.5 & 16.6 & 15.6 \\
\hline Tax on transporters & 1.1 & 0.6 & 1.0 & 1.1 & 1.2 & 1.6 \\
\hline Rental income tax & 0.8 & 1.0 & 1.2 & 1.3 & 0.0 & 0.0 \\
\hline Payroll tax & 2.6 & 2.5 & 3.7 & 3.9 & 4.6 & 4.7 \\
\hline Propenty taxes & 2.6 & 3.4 & 6.4 & 4.9 & 3.2 & 4.8 \\
\hline Taxes on goods and services & 15.0 & 17.0 & 25.4 & 26.5 & 30.9 & 39.8 \\
\hline Value-added tax ${ }^{2}$ & 11.8 & 13.8 & 22.8 & 22.9 & 24.4 & 30.4 \\
\hline Public enterprises & 2.7 & 4.5 & 3.0 & 2.6 & 4.4 & 2.5 \\
\hline Private enterprises & 9.1 & 9.3 & 19.8 & 20.4 & 20.0 & 27.9 \\
\hline Excise duties $^{3}$ & 1.7 & 1.4 & 0.7 & 1.8 & 1.6 & 1.4 \\
\hline Other & 1.5 & 1.8 & 1.9 & 1.8 & 4.9 & 8.0 \\
\hline Taxes on international trade & 55.1 & 73.0 & 94.5 & 112.6 & 127.8 & 135.4 \\
\hline Customs duties $^{3}$ & 2.7 & 5.4 & 6.6 & 7.8 & 10.7 & 23.8 \\
\hline Other import charges ${ }^{3}$ & 17.2 & 22.9 & 28.9 & 35.6 & 37.2 & 7.2 \\
\hline Value-added tax on imports ${ }^{2}$ & 13.3 & 20.8 & 31.6 & 34.2 & 35.3 & 45.1 \\
\hline Petroleum import duties ${ }^{3}$ & 19.2 & 21.2 & 24.6 & 29.2 & 33.4 & 48.3 \\
\hline Payment of deferred taxes & 1.3 & 0.7 & 1,2 & 1.7 & 0.8 & 1.1 \\
\hline Export duty ${ }^{4}$ & 0.0 & 0.1 & 0.1 & 2.1 & 3.4 & 3.0 \\
\hline Other & 1.4 & 1.9 & 1.5 & 2.0 & 7.0 & 7.0 \\
\hline Other tax revenue & 11.8 & 9.0 & 8.3 & 10.6 & 12.0 & 16.0 \\
\hline Stamp duties & 3.6 & 4.8 & 5.3 & 5.3 & 5.8 & 6.8 \\
\hline Payment of tax arrears & 6.5 & 2.8 & 2.0 & 2.0 & 2.3 & 5,0 \\
\hline Other taxes & 1.7 & 1.4 & 1.1 & 3.4 & 4.0 & 4.3 \\
\hline Tax revenue & 103.3 & 131.5 & 172.8 & 196.3 & 221.3 & 235.3 \\
\hline Nontax revenue & 6.1 & 9.0 & 12.2 & 11.6 & 10.4 & 12.6 \\
\hline Capital revenue & 2.7 & 0.0 & 0.0 & 0.0 & 0.0 & 0.0 \\
\hline Budgetary revenue & 109.3 & 140.5 & 185.0 & 207.9 & 231.7 & 247.9 \\
\hline Special funds and annexed budgets & 12.9 & 16.6 & 20.9 & 21.8 & 23.2 & 24.8 \\
\hline Totsil revenue & 122.2 & 157.1 & 206.0 & 229.7 & 2549 & 272.6 \\
\hline
\end{tabular}

Source: Malian authorities.

'Data may not add up becsuse of rounding.

${ }^{2}$ Introduced in 1990 and replaced turnover tax.

${ }^{3}$ Beginning in 1991, tax revenues included in this category, which were previously earmarked for special funds, have been consolidated in the budget.

${ }^{4}$ Custarns service fee on gold exports. 
Table [7. Mali: Goverament Revesue Pesfomance, 1994-99"

\begin{tabular}{|c|c|c|c|c|c|c|}
\hline & 1994 & 1995 & 1996 & 1997 & 1998 & $\begin{array}{c}1999 \\
\text { Est. }\end{array}$ \\
\hline & \multicolumn{6}{|c|}{ (In billious of CPA franes) } \\
\hline Taxes on at income and profits & 16.2 & 26.6 & 34.5 & 37.8 & 42.8 & 34.6 \\
\hline Taxes on goods and services & 15.0 & 17.0 & 25.4 & 26.5 & 30.9 & 39.8 \\
\hline Paytoll tax & 26 & 2.5 & 3.7 & 3.9 & 4.6 & 4.9 \\
\hline Property taxes & 2.6 & 3.4 & 6.4 & 4.9 & 3.2 & 4.8 \\
\hline Taxes on invernarional trade & 55.1 & 73.0 & 94.5 & 112.6 & 127.8 & 135.4 \\
\hline Other tax revenuze & 11.8 & 9.0 & 8.3 & 10.6 & 12.0 & 16.0 \\
\hline Tax tevenue & 103.3 & 131.5 & 172.8 & 196.3 & 221.3 & 235.3 \\
\hline Kontax neverue & 6.1 & 9.0 & 12.2 & 11.6 & 10.4 & 2.6 \\
\hline Capinal kevenne & 2.7 & 0.0 & 0.0 & 0.0 & 0.0 & 0.0 \\
\hline Budgetary revesue & 109.3 & 140.5 & 185.0 & 207.9 & 231.7 & 247.9 \\
\hline Special funds and annexed budgets & 12.9 & 16.6 & 20.9 & 21.8 & 23.2 & 24.8 \\
\hline \multirow[t]{2}{*}{ Total revelue } & 122.2 & 157.1 & 296.0 & 229.7 & 254.9 & 272.6 \\
\hline & \multicolumn{6}{|c|}{ (Avruual percentage chenge) } \\
\hline Taxes on net incame and profits & 39.7 & 64.2 & 29.7 & 9.6 & 13.2 & -19.2 \\
\hline Taxes on proods and gervices & 21.0 & 19.3 & 49.4 & 4.3 & 16.6 & 28.8 \\
\hline Taxes on international trade & 16.2 & 32.5 & 29.5 & 99.2 & 13.5 & 5.9 \\
\hline Other lax revenue & 86.5 & -23.4 & -7.8 & 28.1 & 13.0 & 33.3 \\
\hline Tax revecue & 24.5 & 27.4 & 31.4 & 13.6 & 12.7 & 6.3 \\
\hline Nontax revenule & -41.3 & 48.8 & 36.0 & -5.2 & -10.3 & 21.2 \\
\hline Budgetary revenue & 17.3 & 28.5 & 31.7 & 12.4 & 11,4 & 7.0 \\
\hline Special funds amd ansexed budgets & 20.9 & 28.3 & 26.1 & 4.1 & 6.4 & 6.7 \\
\hline \multirow{2}{*}{ Total revenue } & 17.7 & 28.5 & 31.1 & 11.5 & 11.0 & 6.9 \\
\hline & \multicolumn{6}{|c|}{ (in percent of budgetary revenue) } \\
\hline Taxes on net income and profits & 14.8 & 18.9 & $1,8.6$ & 18.2 & 18.5 & 14.0 \\
\hline Taxes on goods and servioes & 13.7 & 12.] & 13.7 & 12.7 & {$[3.3$} & 16.] \\
\hline Tixes on itternarional trade & 50.4 & 520 & 51.9 & 54.2 & $\$ 5.2$ & 54.6 \\
\hline Other tax revenue & 10.8 & 6.4 & 4.5 & 5.1 & $s .2$ & 6.5 \\
\hline Tax revenue & 94.5 & 93.6 & 93.4 & 94.4 & 95.5 & 94.9 \\
\hline \multirow[t]{2}{*}{ Nontax revenue } & 5.5 & 6.4 & 6.6 & 5.6 & 4.5 & 5.1 \\
\hline & \multicolumn{6}{|c|}{ (In percent of total govertunent revenue) } \\
\hline Budgetary revenue & 89.4 & 89.4 & 89.8 & 90.5 & 90.9 & 90.9 \\
\hline \multirow[t]{2}{*}{ Special funds and anmexed budgets } & 10.6 & 10.6 & 10.1 & 9.5 & 9.1 & 9.1 \\
\hline & \multicolumn{6}{|c|}{ (In percent of GDP) } \\
\hline Taxes on aet income and profits & 1.6 & 2.2 & 2.6 & 2.6 & 2.8 & 2.2 \\
\hline Taxes on goods and services & 1.5 & 1.4 & 1.9 & 1.8 & 2.0 & 2.5 \\
\hline Taxes on international trade & 5.4 & 5.9 & 7.1 & 7.8 & 8.2 & 8.4 \\
\hline Other tax revenue & 1.1 & 0.7 & 0.6 & 0.7 & 0.8 & 1.0 \\
\hline Tax revenue & 10.0 & 10.7 & 12.9 & 13.6 & 14.2 & 147 \\
\hline Noptax reveroue & 0.6 & 0.7 & 0.9 & 0.8 & 0.7 & 0.8 \\
\hline Budgetary revenue & 10.6 & 11.4 & 13.8 & 14,4 & 14.9 & 15.4 \\
\hline Special funds and annexed budgets & 1.3 & 1.3 & 1.6 & 1.5 & 1.5 & 15 \\
\hline Total revesue & 11.9 & 12.8 & 15.4 & 15.9 & 16.4 & 17.0 \\
\hline
\end{tabular}

Sourcess: Malian authorities; and Fund staff estimanes.

'Data may not add up because of rounding. 
Table 19. Mab: Goverwnent Expenditure, 1994-992

\begin{tabular}{|c|c|c|c|c|c|c|}
\hline & 1994 & 1995 & 1996 & 1997 & 1998 & $\begin{array}{l}1999 \\
\text { Fst. }\end{array}$ \\
\hline & \multicolumn{6}{|c|}{ (In billions or CFA francs) } \\
\hline Expendinure and net lending & 266.4 & 289,4 & 314.2 & 345.2 & 383.5 & 417,6 \\
\hline Budgetary expenditure & 268.4 & 291.8 & 303.9 & 328.6 & 363.9 & 395.0 \\
\hline Qurrent expentintre & 132.1 & 134.7 & 137.1 & 167.7 & 167.8 & 193.2 \\
\hline Persounel & 44.5 & 48.0 & 50.6 & 56.8 & 60.7 & 65.3 \\
\hline Suppires & 14.2 & 18.6 & 20.1 & 25.2 & $24 . T$ & 26.7 \\
\hline Scholarships & 4.2 & 3.9 & 4.3 & 4.3 & 5.3 & 6.2 \\
\hline Interest ${ }^{2}$ & 23.9 & 17.6 & 14.5 & 13.8 & 11.7 & 14.0 \\
\hline Other curreml expenditure & 45.3 & 46.6 & 47.6 & 67.6 & 65.4 & 81.0 \\
\hline Copital expenditure, PES.AP, VDP, and NP' & 1363 & 157.1 & 1668 & 160.9 & 196.1 & 201.7 \\
\hline Capital expendiarre & 128.7 & 152]$. & 161.6 & 156.4 & 194.] & 199.7 \\
\hline Externally financed & $1 I S .0$ & 233.5 & 137.3 & $\mathrm{~L} 24.5$ & 149.4 & 347.4 \\
\hline Equijment and investment & 13.7 & 18.6 & 24.3 & 31.9 & 44.7 & 52.3 \\
\hline PESAP & 5.1 & 2.3 & 2.5 & 2.1 & 2.0 & 2.0 \\
\hline Volentary degarture program (VDP) & 0.8 & 0.3 & 0.0 & 0.6 & 0.0 & 0.0 \\
\hline Nationa] Paci (NP) & 3.7 & 2.4 & 2.7 & 1.8 & 0.0 & 0.0 \\
\hline Special funds and annexed budgets & 12.9 & 16.6 & 20.9 & 21.8 & 23.2 & 24.8 \\
\hline \multirow[t]{2}{*}{ Net lending } & -14.9 & $\cdot 19.0$ & -10.6 & -5.2 & -3.6 & .2 .2 \\
\hline & \multicolumn{6}{|c|}{ (Annual percentage chmge) } \\
\hline Expenditure snd aet lending & 50.3 & 8.6 & 8.6 & 9.9 & 11.1 & 8.9 \\
\hline Budgetary expenditure & 66.5 & 8.7 & 4.1 & 8.1 & 10.7 & 8.5 \\
\hline Current expenditure & 49.9 & 20 & 1.8 & 22.3 & 0.1 & 15.2 \\
\hline Personed & B.8 & 7.9 & 5.5 & 12.2 & 6.9 & 7.6 \\
\hline Supplies & 61.4 & 31.0 & 8.1 & 25.4 & -2.0 & 8.3 \\
\hline Scholarstips & -12.5 & -7.1 & 10.3 & 0.0 & 23.3 & 17.7 \\
\hline Other expenditure & 111.7 & 29 & 2.1 & 42.1 & -3.3 & 23.8 \\
\hline Capital expenditure, PESAP, VDP, and $N^{3}$ & 86.5 & 153 & 6.2 & -3.5 & 21.9 & 2.9 \\
\hline Capital expenditure & 90.7 & 18.2 & 6.2 & -3.2 & 24.1 & 2.9 \\
\hline Externally finahted & 96.6 & 16.1 & 2.8 & -9.3 & 20.0 & -1.3 \\
\hline Equịment and investment & 52.2 & 35.8 & 30.6 & 31.3 & 40.1 & 17.0 \\
\hline \multirow[t]{2}{*}{ Special funds and annexed budgets } & 23.2 & 28.3 & 26.1 & 4.1 & 6.4 & 6.7 \\
\hline & \multicolumn{6}{|c|}{ (In percen af total budgetary expenditure) } \\
\hline Curreant expenditure & 49.2 & 46.2 & 45.3 & 51.0 & 46.1 & 48.9 \\
\hline Pensconnel & 16.6 & 16.4 & 16.7 & 17.3 & 16.7 & 16.5 \\
\hline Supplies & 5.3 & 6.4 & 6.6 & 7.7 & 6.E & 6.8 \\
\hline Scholarships & 1.6 & 1.3 & 1.4 & 1.3 & 1.5 & 1.6 \\
\hline Orher experditace & 16.9 & 16.0 & $\$ 5.7$ & 20.6 & 18.0 & 20.5 \\
\hline Capitel expenditure, PESAF, VDP, and NP ${ }^{3}$ & 50.8 & 53.8 & $\$ 4.9$ & 49.0 & 53.9 & 51.1 \\
\hline Capital expenditure & 48.0 & 52.1 & 53.2 & 47.6 & 53.3 & 50.6 \\
\hline Exkernally financed & 42.8 & 45.8 & 45.2 & 37.9 & 41.1 & 37.3 \\
\hline Equipmeat and investment & 5.1 & 6.4 & 8.0 & 9.7 & 12.3 & 13.2 \\
\hline \multirow[t]{2}{*}{ PESAP, VDP, and NP } & 2.8 & 1.7 & 1.7 & 1.4 & 0.5 & 0.5 \\
\hline & \multicolumn{6}{|c|}{ (In percent of total expenditure and net lending) } \\
\hline Budgetary expenditure & 100.7 & $100-8$ & 96.7 & 95.2 & 94.9 & 94.6 \\
\hline Special finads sad amexed budgets & 4.9 & 5.7 & 6.7 & 6.3 & 6.0 & 5.9 \\
\hline \multirow[t]{2}{*}{ Net lending } & -5.6 & .6 .6 & -3.4 & -1.5 & -0.9 & -0.5 \\
\hline & \multicolumn{6}{|c|}{ (It percent or GDP) } \\
\hline Expenditure and net lending & 25.9 & 23.5 & 23.5 & 23.9 & 24.7 & 26.0 \\
\hline Budgetary expenditure & 26.1 & 23,7 & 22.7 & 22.7 & 23.4 & 24.6 \\
\hline Curfent expendhure & 12.8 & 10.9 & 10.7 & 13.6 & 10.8 & 12.0 \\
\hline Personnel & 4.3 & 3.9 & 3.8 & 3.9 & 3.9 & 4.] \\
\hline Supplies & 1.4 & 1.5 & 1.5 & 1.7 & 1.6 & 1.7 \\
\hline Scholarships & 0.4 & 0.3 & 0.3 & 0.3 & 0.3 & 0.4 \\
\hline Other expenditure & 4.4 & 3.8 & 3.6 & 4.3 & 4.2 & s.o \\
\hline Cap̧ital expenditure, PESAP, VDP, and NP ${ }^{3}$ & 13.2 & L2.8 & 12.4 & เ $\$ .1$ & 12.6 & 12.6 \\
\hline Capital expendiurse & 12.5 & 12.4 & 12.1 & to.s & 12.5 & 12.4 \\
\hline Extemally funanced & 112 & $10 . \bar{B}$ & 102 & 8.6 & 9.6 & 9.2 \\
\hline Equipment and investment & 1.3 & 1.5 & 18 & 2.2 & 2.9 & 3.3 \\
\hline PESAP, VDP, and NP & 0.7 & 0.4 & 0.4 & 0.3 & 0.5 & 0.1 \\
\hline Specizl funds and atenexed budgets & 1.3 & 1.3 & 1.6 & 1.5 & 1.5 & 1.5 \\
\hline Net leading & $-[.4$ & -1.5 & -0.8 & .0 .4 & -0.2 & -8.1 \\
\hline
\end{tabular}

Sources: Malian authorities; and Fund staff estimates.

'Data may not add up because of rounding.

'Scheduied; after debt cancellation obrained through 1993.

'PESAP, Public Enterprise Sector Adjuscment Program, finaned by the World Baak and cotinanciers 
Table 19. Mali: Functionnal Classification of Budgetary Expenditures, 1994-99

(In millions CFA francs)

\begin{tabular}{|c|c|c|c|c|c|c|}
\hline & 1994 & 1995 & 1996 & 1997 & 1998 & $\begin{array}{r}1999 \\
\text { Est. }\end{array}$ \\
\hline Total expenditure & 260,860 & 286,840 & 298,670 & 324,100 & 361,900 & 392,985 \\
\hline Current expenditure & 132,100 & 134,700 & 137,100 & 167,700 & 167,800 & 193,245 \\
\hline General public services & 18,490 & 21,861 & 24,018 & 25,432 & 29,796 & 39,761 \\
\hline Defense & 20,883 & 24,689 & 25,267 & 28,337 & 29,298 & 32,674 \\
\hline Education & 22,302 & 26,657 & 29,522 & 32,416 & 35,341 & 40,455 \\
\hline Health & 8,161 & 8,701 & 9,358 & 11,126 & 13,300 & 11,136 \\
\hline Social services & 2,874 & 3,541 & 4,079 & 4,463 & 5,220 & 6,210 \\
\hline Economic services & 17,292 & 18,210 & 19,328 & 21,891 & 20,670 & 22,751 \\
\hline Other & 42,098 & 31,041 & 25,528 & 44,035 & 34,175 & 40,258 \\
\hline Of which: interest on public debt & 23,900 & 17,600 & 14,500 & 13,800 & 11,700 & 14,000 \\
\hline Capital expenditure & 128,760 & 152,140 & 161,570 & 156,400 & 194,100 & 199,740 \\
\hline General public services & 9,471 & 4,820 & 15,253 & 10,459 & 8,469 & 9,789 \\
\hline Defense & 1,302 & 2,227 & 1,835 & 2,967 & 2,920 & 3,297 \\
\hline Education & 7,463 & 6,283 & 9,286 & 10,358 & 10,255 & 18,447 \\
\hline Health & 10,966 & 10,164 & 13,640 & 10,600 & 6,918 & 6,120 \\
\hline Social services & 6,467 & 8,644 & 8,809 & 7,286 & 8,143 & 11,605 \\
\hline Economic services & 76,250 & 78,616 & 106,600 & 105,107 & 145,375 & 134,666 \\
\hline Other & 221,737 & 253,254 & 286,487 & 282,259 & 359,242 & 364,086 \\
\hline
\end{tabular}

Sources: Malian authorities; and Fund staff estimates. 
Table 20. Mali: Consolidated Operations of the Special Funds and the Annexed Budgets, 1994-99

(In billions of CFA francs)

\begin{tabular}{|c|c|c|c|c|c|c|}
\hline & 1994 & 1995 & 1996 & 1997 & 1998 & $\begin{array}{r}1999 \\
\text { Est. }\end{array}$ \\
\hline Revenuse & 12.9 & 16.6 & 20.9 & 21.8 & 23.2 & 24.8 \\
\hline Social Security Fund (NNPS) & 11.8 & 15.0 & 19.1 & 20.1 & 21.5 & 22.9 \\
\hline Other revenue ${ }^{1}$ & 1.1 & 1.5 & 1.8 & 1.7 & 1.7 & 1.9 \\
\hline Expenditure and net lending & 12.9 & 16.6 & 20.9 & 21.8 & 23.2 & 24.8 \\
\hline Social Security Fund (INPS) & 11.8 & 15.0 & 19.1 & 20.1 & 21.5 & 22.9 \\
\hline Other expenditure' & 1.1 & 1.6 & 1.8 & 1.7 & 1.7 & 1.9 \\
\hline Surplus/deficit & 0.0 & 0.0 & 0.0 & 0.0 & 0.0 & 0.0 \\
\hline
\end{tabular}

Source: Malian authorities.

'Includes the National Housing Fund (FNL), the Central Veterinary Laboratory (LCV), the National Lottery (LONAMA), and the National Institute of Research in Public Health (INRSP). 
Table 21. Mali: Govemment Wage Bill and Employees, 1994-99

\begin{tabular}{|c|c|c|c|c|c|c|}
\hline & 1994 & 1995 & 1996 & 1997 & 1998 & $\begin{aligned} 1999 \\
\text { Est. }\end{aligned}$ \\
\hline \multicolumn{7}{|l|}{ Wage bill } \\
\hline (in billions of CFA francs) & 44.5 & 48.0 & 50.6 & 56.8 & 60.7 & 65.3 \\
\hline \multicolumn{7}{|l|}{ Annual change in wage bill } \\
\hline (in percent) & 8.8 & 7.9 & 5.5 & 12.2 & 6.9 & 7.6 \\
\hline \multicolumn{7}{|l|}{ Wage bill } \\
\hline (in percent of current budgetary expenditure) & 33.7 & 35.6 & 36.9 & 33.9 & 36.2 & 33.8 \\
\hline \multicolumn{7}{|l|}{ Wage bill } \\
\hline (in percent of total budgetary expenditure) & 16.6 & 16.4 & 16.7 & 17.3 & 16.7 & 16.5 \\
\hline \multicolumn{7}{|l|}{ Wage bill } \\
\hline (in percent of GDP) & 4.3 & 3.9 & 3.8 & 3.9 & 3.9 & 4.1 \\
\hline \multicolumn{7}{|l|}{ Total government employees } \\
\hline as of end-December & 32,719 & 32,527 & 36,138 & 37,360 & 37,841 & 38,750 \\
\hline Of which: civil servants & 29,141 & 29,067 & 31,961 & 33,235 & 33,534 & 34,226 \\
\hline $\begin{array}{l}\text { Annual change in total government employees } \\
\text { (in percent) }\end{array}$ & -9.3 & -0.6 & 11.1 & 3.4 & 1.3 & 2.4 \\
\hline
\end{tabular}

Source: Malian authorities. 
Table 22. Mali - Deposit Money Banks, Decumber 1999

\begin{tabular}{|c|c|c|c|c|c|c|c|c|}
\hline \multirow{3}{*}{ Banque de Développement du Mali } & \multirow{3}{*}{ Shareholders } & \multirow{3}{*}{$\begin{array}{c}\begin{array}{c}\text { Percent of } \\
\text { Total } \\
\text { Holdings }\end{array} \\
20.0\end{array}$} & \multirow{3}{*}{$\begin{array}{c}\begin{array}{c}\text { Year } \\
\text { Established }\end{array} \\
1968\end{array}$} & \multirow{3}{*}{$\begin{array}{c}\begin{array}{c}\text { Copital } \\
\text { (In millionts of } \\
\text { CFA francs) }\end{array} \\
3,000\end{array}$} & \multicolumn{3}{|c|}{ Deposits. } & \multirow{3}{*}{$\begin{array}{r}\begin{array}{c}\text { Number } \\
\text { of } \\
\text { Branches }\end{array} \\
14\end{array}$} \\
\hline & & & & & $\begin{array}{l}\text { Public } \\
\text { (In milli }\end{array}$ & $\begin{array}{l}\text { Private } \\
\text { ns of CFA fot }\end{array}$ & $\begin{array}{l}\text { Total } \\
\text { ncs) }\end{array}$ & \\
\hline & & & & & 54,161 & 58,814 & 112,975 & \\
\hline$(\mathrm{BDM}-\mathrm{SA})^{\prime}$ & $\begin{array}{l}\text { BCEAO } \\
\text { WADB } \\
\text { Private national shareholders } \\
\text { Morocean bank }\end{array}$ & $\begin{array}{l}20.0 \\
20.0 \\
23.3 \\
16.7\end{array}$ & & & & & & \\
\hline $\begin{array}{l}\text { Banque Nationale de Développement } \\
\text { Agricole (BNDA) }\end{array}$ & $\begin{array}{l}\text { Government } \\
\text { BCEAO } \\
\text { Caisse Française } \\
\text { de Dèveloppement } \\
\text { (France) } \\
\text { Deulsche Entwicklungs } \\
\text { Gesellschaft (Federal } \\
\text { Republic of Gernany) } \\
\text { BDM-SA }\end{array}$ & $\begin{array}{r}39.5 \\
16.8 \\
\\
19.6 \\
\\
\\
18.5 \\
5.6\end{array}$ & 1981 & 9,456 & 8,298 & 12,248 & 20,546 & 22 . \\
\hline Bangque Internationale du Mali (BIM-SA) ${ }^{2}$ & $\begin{array}{l}\text { Government } \\
\text { Ptivate national shareholders }\end{array}$ & $\begin{array}{l}61.5 \\
38.5\end{array}$ & 1980 & 4,255 & 3,171 & 50,207 & 53,378 & 6 \\
\hline $\begin{array}{l}\text { Banque Malienne de Crédit et de } \\
\text { Dépóts (BMCD) }\end{array}$ & Government & 100.0 & 1966.1 & 1,000 & 8,427 & 43,642 & 52,069 & 7 \\
\hline Bank of Africa-Mali (BOA) & $\begin{array}{l}\text { Private national shareholders } \\
\text { Private foreigth shareholdets }\end{array}$ & $\begin{array}{l}76.6 \\
23.4\end{array}$ & 1982 & 2,000 & 6,293 & 41,550 & 47,843 & 5 \\
\hline Banque Commerciale du Sahel (BCS; ex-BAIIMA) & $\begin{array}{l}\text { Govemment } \\
\text { Foreiga Atab banks } \\
\text { Private national shareholders }\end{array}$ & $\begin{array}{r}49.5 \\
50.0 \\
0.5\end{array}$ & 1982 & 1,100 & $13,3,49$ & 9,269 & 22,618 & 1 \\
\hline Banque de J'Habitat du Mali (BHM) ${ }^{3}$ & $\begin{array}{l}\text { Govemment } \\
\text { INPS }^{4} \\
\text { ACI }^{5} \\
\text { BIM-SA } \\
\text { Private national shareholders }\end{array}$ & $\begin{array}{r}14.8 \\
37.1 \\
25.9 \\
7.4 \\
14.8\end{array}$ & 1991 & 4,000 & 5,220 & $\pm 1,203$ & 16,423 & 1 \\
\hline $\begin{array}{l}\text { Banque Inlemationaie pour le Connerce et } \\
\text { l'Industrie du Mali (BICIM) }\end{array}$ & $\begin{array}{l}\text { Govenoment } \\
\text { Banque Nationale de Paris } \\
\text { SFOM (Switzertand) } \\
\text { BMCI" (Mauritania) }\end{array}$ & $\begin{array}{l}15.0 \\
20.0 \\
50.0 \\
15.0\end{array}$ & 1999 & 2,000 & 0.00 & 9,420 & 9,420 & 1 \\
\hline Ecobank $^{6}$ & $\begin{array}{l}\text { Ecobank Transnational Ine. } \\
\text { Ecabank - Togo } \\
\text { Ecobank-Benin } \\
\text { Private foreign shareholdess }\end{array}$ & $\begin{array}{r}58.0 \\
16.7 \\
25.0 \\
0.3\end{array}$ & 1998 & 1500 & 619.00 & 5808 & 6.427 & I \\
\hline
\end{tabular}

Source: Central Bank of West African States (BCEAO).

1 Restructured into a joint stock company on June 30, 1989.

2 Fomerly the Banque Internationale pour l'Afrique Occidentaie an Mali (BJAO-Mali).

${ }^{3}$ Was changed to a Bank from the Société des Chèques Postaux et de la Caisse d'Epargne (SCPCE) in March 1996.

4 Institut National de Prévoyance Sociale.

Agence Cession Immobilière.

${ }^{6}$ Created in 1998.

'SFOM: Société Financière pour les pays d'Outre Mer

${ }^{8}$ BMCl: Banque Marritanieane pour le Commerce el VIndustrie 
Talje 23. Mali : Monetary Survey, 1994.99

an billions of CFA franes; end of period)

\begin{tabular}{|c|c|c|c|c|c|c|c|c|c|c|c|c|}
\hline & \multirow[t]{2}{*}{1991} & \multirow[t]{2}{*}{1995} & \multirow[t]{2}{*}{1996} & \multirow[t]{2}{*}{1997} & \multicolumn{4}{|c|}{$19 \% 8$} & \multicolumn{4}{|c|}{1999} \\
\hline & & & & & Mar. & Juท. & Sep. & Dex. & Mar & Jua. & Sop & Dee. \\
\hline Foreign assets $\left\{(n=1)^{3}\right.$ & $\$ 10.3$ & 147.3 & 2127 & 211.2 & 208.7 & 197.6 & 179.5 & 175.3 & 199.0 & 379.4 & 125.8 & 138.1 \\
\hline BCEAO & 52.7 & 80.9 & 143.8 & 142.5 & 152.3 & 142.6 & 118.2 & $\$ 20.2$ & 141.9 & 218.3 & 81.5 & 108.0 \\
\hline Deposit money benks & 57.6 & 66.4 & 68.9 & 68.7 & 56.4 & 55.0 & 61.3 & 55.1 & 57.1 & 65.1 & 44.3 & 30.1 \\
\hline Nel donegreic assels & 136.2 & 144.8 & 114.0 & 145.6 & 200.1 & 177,4 & 177.1 & 193.9 & 253.6 & 259.2 & 310.3 & 2338 \\
\hline Of which: BCEAO $^{3}$ & 67.3 & 50.8 & 0.7 & 24.0 & 39.0 & 39.1 & 41.8 & 37.2 & 58.3 & 64.5 & 82.3 & 69.3 \\
\hline Credit to the governument (net) & $\$ 9.1$ & 16.6 & .23 .6 & -23.9 & -19.5 & -17.9 & -20.9 & -25.9 & -1.3 & 15.6 & 45.3 & -22.0 \\
\hline Central bank ${ }^{4}$ & 63.0 & 53.4 & 26.8 & 29.2 & 38.1 & 43.8 & $40, \pi$ & 42.3 & 57.8 & 66.3 & 82.4 & 31.4 \\
\hline Conmmetcial burks & .11 .8 & -35.3 & 484 & .48 .6 & -52.6 & -58.0 & -57.6 & -64.2 & $-\$ 4.3$ & -45 & .31 .2 & -88.3 \\
\hline Other & -2.1 & -1.5 & -2.0 & -4.5 & .5 & -3.7 & -4.1 & -4.0 & -5.2 & -5.7 & -5.9 & .5 .1 \\
\hline Credit to the econorny & 81.0 & 131.1 & $\$ 71.2$ & {$[95.9$} & 239.8 & 216.6 & 210.4 & 251.0 & $2 \mathrm{~B} 4.5$ & 270.3 & 288.0 & 286.5 \\
\hline Crap credit & 0,4 & 4.6 & 2.9 & 1.0 & 43.6 & 45.4 & 20.1 & 32.2 & 480 & 480 & 27.2 & 17.5 \\
\hline Ordinary credic & 80.6 & 126.5 & 16R.3. & 194.9 & $\$ 96.2$ & 1312 & 1903 & 238.8 & 236.5 & 2223 & 260.8 & 269.0 \\
\hline Other items (net) ${ }^{3}$ & 6.1 & -2.9 & -33.6 & -26.4 & .20 .2 & -21.3 & .124 & .312 & -31.2 & -26.7 & .230 & -30.7 \\
\hline Central benk & 4.3 & -2.6 & -16.1 & .52 & -10.5 & .4 .7 & -20 & $-\$ .1$ & -4.1 & .12 & -1.7 & -2.1 \\
\hline Commercial banks & 1.8 & \$.3.3 & -17.5 & -21.2 & -9.7 & .16 .6 & -10.4 & -26.1 & -23.1 & -25.5 & -21.3 & -28.6 \\
\hline Medium- and long-tem external Lisbillities & .11 .1 & -8.9 & -10.3 & -15.2 & .13 .2 & -12.7 & .12 .9 & $\cdot 12.3$ & $-\$ 2.1$ & -11.5 & -11.5 & -11.3 \\
\hline Revaluation accoun: & 1.1 & $\$ 1$ & 1.1 & 1.1 & 7.1 & 7.1 & 3.1 & 1.1 & 1.0 & 1.0 & 1.0 & 11 \\
\hline BCEAO & 4.1 & 4.1 & 4.1 & 4.1 & 4.1 & 4.1 & 4.1 & 4.1 & 40 & 40 & 4.0 & 4.1 \\
\hline Deposit money banks & .30 & .30 & -3.0 & -30 & 30 & 3.0 & 3.0 & -3.0 & -3.0 & -3.0 & .3 .0 & -3.0 \\
\hline Money supply (M2) & 237.0 & 283.6 & 317.3 & 345.0 & 394.5 & 361.3 & 342.6 & $359 . \mathrm{K}$ & 4.30 .4 & 409.8 & 383.3 & 364.6 \\
\hline Corrency in eireulation & 90.4 & 1074 & 120.4 & 129.5 & 146.7 & 137.5 & 124.1 & 135.3 & 160.5 & 155.1 & 132.5 & 123,7 \\
\hline Bark deposils & 146.6 & 176.2 & 1969 & 215.5 & 247.8 & 223.8 & 218.5 & 224.5 & 269.9 & 254.7 & 250.8 & 2409 \\
\hline
\end{tabular}

Sources: Central Bank of West African Sizates (BCEAO); and limd stuff estimates

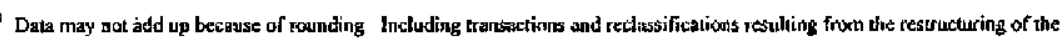

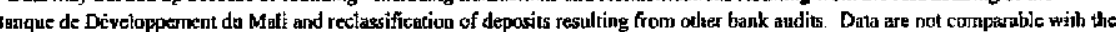

previous RDD tsbles for 1990 as these were adjusted to a I987 accounting hasse to previde coniparability with previous years.

"Exeluding SDR allocations and modium- and long-terme lialtilitues.

${ }^{3}$ Defined as base money minus net foreign assels.

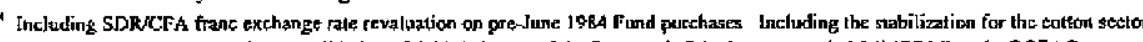

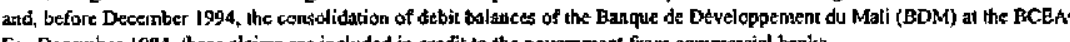

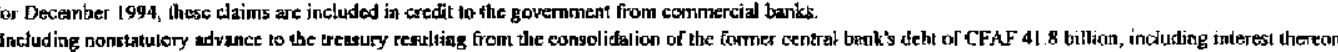


Table 24. Mali: Summary Accounts of the Central Bank, 1994-99 ${ }^{1}$

(In billions of CFA francs; end of period)

\begin{tabular}{|c|c|c|c|c|c|c|}
\hline & 1994 & 1995 & 1996 & 1997 & 1998 & $\begin{array}{r}1999 \\
\text { Est. }\end{array}$ \\
\hline Foreign assets (net) & 52.7 & 80.9 & 143.8 & 142.5 & 120.2 & 108.0 \\
\hline Assets & 118.6 & 158.6 & 226.0 & 248.3 & 228.6 & 227.9 \\
\hline Liabilities $^{2}$ & -65.9 & -77.7 & $-82,2$ & -105.8 & -108.4 & -119.9 \\
\hline Net domestic assets & 67.3 & 50.8 & 10.7 & 24.0 & 37.2 & 69.3 \\
\hline Claims on the government (net) & 63.0 & 53.4 & 26.8 & 29.2 & 42.3 & 71.4 \\
\hline Claims & 75.8 & 80.5 & 90.4 & 99.8 & 106.0 & 112.9 \\
\hline Of which: Consolidated claims ${ }^{3}$ & 0.0 & 4.7 & 3.1 & 0.0 & 4.2 & 3.7 \\
\hline Liabilities ${ }^{4}$ & -12.8 & -27.1 & -63.6 & -70.6 & -63.7 & -41.5 \\
\hline Other items (net) & 4.3 & -2.6 & -16.1 & -5.2 & -5.1 & -2.1 \\
\hline Claims on deposit money banks (net) & -25.5 & -20.2 & -30.0 & -32.9 & -18.0 & -49.5 \\
\hline Claims & 0.0 & 0.0 & 0.0 & 0.0 & 0.0 & 0.0 \\
\hline Advances to money market & 0.0 & 0.0 & 0.0 & 0.0 & 0.0 & 0.0 \\
\hline Rediscounts and other advances & 0.0 & 0.0 & 0.0 & 0.0 & 0.0 & 0.0 \\
\hline Liabilities & 25.5 & 20.2 & 30.0 & 32.9 & 18.0 & 49.5 \\
\hline Deposits in money market & 3.7 & 2.4 & 0.0 & 0.0 & 0.0 & 0.0 \\
\hline Other deposits & 14.5 & 10.9 & 19.4 & 21.6 & 10.5 & 38.2 \\
\hline Currency held by banks & 7.3 & 6.9 & 10.6 & 11.3 & 7.5 & 11.3 \\
\hline Revaluation account & 4.1 & 4.1 & 4.1 & 4.1 & 4.1 & 4.1 \\
\hline Currency outside banks & 90.4 & 107.4 & 120.4 & 129.5 & 135.3 & 123.7 \\
\hline
\end{tabular}

Sources: Central Bank of West African States (BCEAO); and Fund staff estimates.

${ }^{1}$ Data may not add up because of rounding.

${ }^{2}$ Excluding SDR counterpart.

${ }^{3}$ These claims were securitized and sold to Malian commercial banks in 1994.

${ }^{4}$ Including cash held by the Treasury. 
Table 25. Mali: Summary Accounts of the Deposit Money Banks, 1994-99 ${ }^{32}$ (In billions of CFA francs; end of period)

\begin{tabular}{|c|c|c|c|c|c|c|}
\hline & 1994 & 1995 & 1996 & 1997 & 1998 & $\begin{array}{r}1999 \\
\text { Est. }\end{array}$ \\
\hline Foreign assets (net) & $\$ 7.6$ & 66.4 & 68.9 & 68.7 & 55.1 & 30.1 \\
\hline Assets & 65.6 & 74.8 & 71.6 & 70.4 & 70.4 & 76.2 \\
\hline Liabilities (short-term) & -8.0 & -8.4 & -2.7 & -1.7 & -15.3 & -46.1 \\
\hline Net domestic assets & 97.1 & 115.7 & 135.3 & 159.0 & 178.7 & 219.1 \\
\hline Claims on the government (net) & -11.8 & -35.3 & -48.4 & -48.6 & -64.2 & -88.3 \\
\hline Claims & 28.0 & 19.0 & 23.1 & 19.6 & 13.8 & 14.0 \\
\hline Deposits & -39.8 & -54.3 & -71.5 & -68.2 & -78.0 & -102.3 \\
\hline Credit to the private sector ${ }^{3}$ & 81,0 & 131.1 & 171.2 & 195.9 & 251.0 & 286.5 \\
\hline Crop credit & 0.4 & 4.6 & 2.9 & 1.0 & 12.2 & 17.5 \\
\hline Other & 80.6 & 126.5 & 168.3 & 194.9 & 238.8 & 269.0 \\
\hline Other items (net) & 1.8 & -0.3 & -17.5 & -21.2 & -26.1 & -28.6 \\
\hline Reserves & 26.1 & 20.2 & 30.0 & 32.9 & 18.0 & 49.5 \\
\hline Money market position (net) & 3.7 & 2.4 & 0.0 & 0.0 & 0.0 & 0.0 \\
\hline Deposits & 3.7 & 2.4 & 0.0 & 0.0 & 0.0 & 0.0 \\
\hline Advances & 0.0 & 0.0 & 0.0 & 0.0 & 0.0 & 0.0 \\
\hline Other reserves & 22.4 & 17.8 & 30.0 & 32.9 & 18.0 & 49.5 \\
\hline Currency holdings & 7.3 & 6.9 & 10.6 & 11.3 & 7.5 & 11.3 \\
\hline Depasits at central bank & 15.1 & 10.9 & 19.4 & 21.6 & 10.5 & 38.2 \\
\hline \multicolumn{7}{|l|}{ Medium- and long-term external } \\
\hline liabilities & -11.1 & -8.9 & -10.3 & -15.2 & -12.3 & -11.3 \\
\hline Revaluation account & -3.0 & -3.0 & -3.0 & -3.0 & -3.0 & -3.0 \\
\hline Deposits & 146.6 & 176.2 & 196.9 & 215.5 & 224.5 & 240.9 \\
\hline Demand & 83.7 & 100.0 & 119.4 & 126.5 & 132.1 & \\
\hline Of which: public enterprises & 9.0 & 7.0 & $\ldots$ & $\ldots$ & $\ldots$ & ... \\
\hline Tíme & 62.9 & 76.2 & 77.5 & 89.0 & 92.4 & \\
\hline Of which: public enterprises & 5.3 & 8.3 & $\ldots$ & $\ldots$ & $\cdots$ & $\cdots$ \\
\hline
\end{tabular}

Sources: Central Bank of West African States (BCEAO); and Fund staff estimates.

${ }^{1}$ Data may not add up because of rounding.

${ }^{2}$ Including transactions and adjustments resulting from the restructuring of the Banque de Développement du Mali, and reclassifications of deposits resulting from other bank audits.

${ }^{3}$ Does not match the credit to the private sector shown in table 22 due to a different classification of collateralized bonds. 
Table 26. Mali: Claims on the Government, 1994-99 ${ }^{3}$

(In billions of CFA francs; end period)

\begin{tabular}{|c|c|c|c|c|c|c|}
\hline & 1994 & 1995 & 1996 & 1997 & 1998 & $\begin{array}{c}1999 \\
\text { Est. }\end{array}$ \\
\hline Central bank, net claims & 63.0 & 53.4 & 26.8 & 29.2 & 42,3 & 71.4 \\
\hline Claims & 75.8 & 80.5 & 90.4 & 99.8 & 106.0 & 112.9 \\
\hline Treasury overdraft & 18.4 & 0.0 & 0.0 & 0.0 & 0.0 & 0.0 \\
\hline Trust Fund on-lent & 0.0 & 0.0 & 0.0 & 0.0 & 0.0 & 0.0 \\
\hline IMF credit on-lent & 57.4 & 75.8 & 87.3 & 99.8 & 101.8 & 109.2 \\
\hline Consolidated claims ${ }^{3}$ & 0.0 & 4.7 & 3.1 & 0.0 & 4.2 & 3.7 \\
\hline Liabilities & 12.8 & 27.1 & 63.6 & 70.6 & 63.7 & 41.5 \\
\hline Treasury currency holdings & 3.0 & 5.2 & 6.6 & 7.6 & 8.4 & 7.5 \\
\hline Government deposits & 9.8 & 21.9 & 57.0 & 63.0 & 55.3 & 34.0 \\
\hline Deposit money banks, net claims & -11.8 & -35.3 & -48.4 & -48.6 & -64.2 & -88.3 \\
\hline Claims $^{3}$ & 28.0 & 19.0 & 23.1 & 19.6 & 13.8 & 14.0 \\
\hline Liabilities & 39.8 & 54.3 & 71.5 & 68.2 & 78.0 & 102.3 \\
\hline Counterparts & -2.1 & -1.5 & -2.0 & -4.5 & -4.0 & -5.1 \\
\hline \multicolumn{7}{|l|}{ Customs duty bills held by the } \\
\hline Treasury & 2.1 & 1.5 & 2.0 & 4.5 & 4.0 & 5.1 \\
\hline Net claims on the government & 49.1 & 16.6 & -23.6 & -23.9 & -25.9 & -22.0 \\
\hline Of which: banking system ${ }^{4}$ & 51.2 & 18.1 & -21.6 & -19.4 & -21.9 & -16.9 \\
\hline
\end{tabular}

Sources: Central Bank of West African States (BCEAO); and Fund staff estimates.

${ }^{1}$ Data may not add up because of rounding.

2 Including transactions and adjustments resulting from the restructuring of the Banque de Développement du Mali (BDM) and reclassifications of deposits resulting from other bank audits.

$3 \mathrm{Up}$ to end-1993, the consolidated debit balances of the BDM at the BCEAO are included in claims of the central bank on the government. These clains were securitized in 1994 and for 1994 are included in claims of the deposit money banks on the government.

4 Includes the cotton stabilization fund. 
Table 27. Mali: Foreign Assets and Liabilities of the Banking System, 1994-99 (In bilions of CFA francs; end period)

\begin{tabular}{|c|c|c|c|c|c|c|}
\hline & 1994 & 1995 & 1996 & 1997 & 1998 & $\begin{array}{r}1999 \\
\text { Est. }\end{array}$ \\
\hline Banking system (net) ${ }^{2}$ & 99.2 & 138.4 & 202.4 & 196.0 & 163.0 & 126.4 \\
\hline Foreign assets & 184.2 & 233.4 & 297.6 & 318.8 & 298.9 & 303.7 \\
\hline Foreign liabilities & 85.0 & 95.0 & 95.2 & $\$ 22.7$ & 136.0 & 177.3 \\
\hline Central bank (net) & 52.7 & 80.9 & 143.8 & 142.5 & 120.2 & 107.6 \\
\hline Foreign assets & 118.6 & 158.6 & 226.0 & 248.3 & 228.6 & 227.5 \\
\hline Foreign exchange & 111.4 & 151.4 & 219.3 & 241.3 & 221.4 & 220.2 \\
\hline Special drawing rights & 0.1 & 0.2 & 0.2 & 0.0 & 0.0 & 0.0 \\
\hline Reserve position in the Fund & 7.1 & 7.0 & 6.6 & 7.0 & 7.1 & 7.4 \\
\hline Foreign liabilities & 65.9 & 77.7 & 82.2 & 105.8 & 108.4 & 119.9 \\
\hline Use of Fund resources & 60.0 & 76.6 & 85.8 & 103.5 & 107.4 & 117.9 \\
\hline Trust Fund & 0.0 & 0.0 & 0.0 & 0.0 & 0.0 & 0.0 \\
\hline Other & 5.9 & 1.1 & -3.6 & 2.3 & 1.0 & 2.0 \\
\hline Deposit money banks (net) & 46.5 & 57.5 & 58.6 & 53.5 & 42.8 & 18.8 \\
\hline Foreign assets & 65.6 & 74.8 & 71.6 & 70.4 & 70.4 & 76.2 \\
\hline Foreign liabilities & 19.1 & 17.3 & 13.0 & 16.9 & 27.6 & 57.4 \\
\hline Short term & 8.0 & 8.4 & 6.9 & 5.9 & 19.5 & 50.3 \\
\hline Medium and long term & 11.1 & 8.9 & 6.1 & 11.0 & 8.1 & 7.2 \\
\hline
\end{tabular}

Sources: Central Bank of West African States (BCEAO); and Fund staff estimates.

1 Data may not add up because of rounding.

2 Differs from net foreign assets in Tables 22 and 24, which exclude medium and long term foreign liabilities. 
Table 28. Mali: Interest Rate Indicators, 1994-99

(In percent per year)

\begin{tabular}{lrrrrrr}
\hline & 1994 & 1995 & 1996 & 1997 & 1998 & 1999 \\
\hline & & & & & & \\
Deposits & 5.50 & 5.75 & 5.00 & 4.50 & 4 & 1 \\
Rediscount rate & 10.00 & 7.50 & 6.50 & 6.00 & 6.25 & 5.75 \\
Money market & 5.50 & 5.75 & 5.00 & 4.50 & 4.95 & 4.95 \\
Savings deposits & 4.50 & 4.50 & 3.50 & 3.56 & 3.50 & 3.50 \\
& & & & & & \\
\hline
\end{tabular}

Sources: Malian authorities; IMF, International Financial Statistics; and Fund staff estimates.

${ }^{\mathfrak{l}}$ Freely determined by commercial banks. 
Table 29. Mali: Central Bank Discount Rates,

November 1989 - June $2000^{1}$

(In percent per year)

\begin{tabular}{lc}
\hline Date & $\begin{array}{c}\text { Discount } \\
\text { Rate }\end{array}$ \\
\hline & \\
27-Nov-89 & 11.00 \\
20-Aug-92 & 13.00 \\
18-Oct-93 & 12.50 \\
20-Dec-93 & 10.50 \\
18-Jan-94 & 14.50 \\
27-Jun-94 & 12.00 \\
01-Aug-94 & 11.00 \\
29-Aug-94 & 10.00 \\
05-Sep-94 & 10.50 \\
23-Jan-95 & 9.00 \\
05-Jun-95 & 8.50 \\
26-Dec-95 & 7.50 \\
05-Aug-96 & 7.25 \\
19-Aug-96 & 7.00 \\
21-Oct-96 & 6.50 \\
17-Feb-97 & 6.25 \\
08-Sep-97 & 6.00 \\
31-Aug-98 & 6.25 \\
04-Jan-99 & 5.75 \\
19-Jun-00 & 6.50 \\
& \\
\hline
\end{tabular}

Source: Central Bank of West African States (BCEAO).

'Rates applied to short-term credit of one year or less and to medium-term credit of up to ten years. The BCEAO will also rediscount long-term credit that, at the time of rediscounting, has no more than 15 years to maturity. 
Table 30. Mali: Interest Rates Applied in the Money Market, March 1994-December $1999^{1}$

(In percent per year)

1994

March

June

September

5.67

December

1995

March

June

5.50

September

5.50

December

1996

March

June

September

5.25

Decernber

5.05

1997

March

June

5.02

September

5.02

December

4.96

1998

March

4.53

June

4.95

September

4.95

December

1999

March

4.95

June

4.95

September

4.95

December

4.95

Source: Centrai Bank of West African States (BCEAO).

'In October 1993, the money market was transformed into an auction of weekly advances. Figures shown are monthly averages. Rates paid on auctions of central bank bills, introduced in August 1996, are not included 
Table 31. Mali: Maximum Lending Rates Applied by Commercial Banks, 1994 - 1999

(In percent per year)

\begin{tabular}{|c|c|c|c|c|c|c|c|c|c|c|c|c|c|c|}
\hline & $\begin{array}{c}\text { Since } \\
18 \text { Jan. } \\
1994\end{array}$ & $\begin{array}{l}27 \text { Jun. } \\
1994\end{array}$ & $\begin{array}{l}\text { 1-Aug. } \\
1994\end{array}$ & $\begin{array}{l}\text { 29-Aug. } \\
1994\end{array}$ & $\begin{array}{l}23 \text { Jun. } \\
1995\end{array}$ & $\begin{array}{l}5 \text { Jun. } \\
1995\end{array}$ & $\begin{array}{l}\text { 26-Dec. } \\
1995\end{array}$ & $\begin{array}{l}\text { 5-Aug. } \\
1996\end{array}$ & $\begin{array}{l}\text { 19-Aug. } \\
1996\end{array}$ & $\begin{array}{r}21-0 \mathrm{ct} . \\
1996\end{array}$ & $\begin{array}{r}\text { 17-Feb. } \\
1997\end{array}$ & $\begin{array}{l}\text { 8-Sep. } \\
1997\end{array}$ & $\begin{array}{r}\text { 5-Sep. } \\
1998\end{array}$ & 1999 \\
\hline \multicolumn{15}{|l|}{ Short- and medium-term credit } \\
\hline $\begin{array}{l}\text { Crop financing and export credit } \\
\text { Financing of storage of }\end{array}$ & 29.0 & 24.0 & 22.0 & 20.0 & 18.0 & 17.0 & 15.0 & 14.5 & 14.0 & 13.0 & 12.5 & 12.0 & 18.0 & 18.0 \\
\hline agricultural products & 29.0 & 24.0 & 22.0 & 20.0 & 18.0 & 17.0 & 15.0 & 14.5 & 14.0 & 13.0 & 12.5 & 12.0 & 18.0 & 18.0 \\
\hline $\begin{array}{l}\text { Credit to small and medium- } \\
\text { sized national enterprises }\end{array}$ & 29.0 & 24.0 & 22.0 & 20.0 & 18.0 & 17.0 & 15.0 & 14.5 & 14.0 & 13.0 & 12.5 & 12.0 & 18.0 & 18.0 \\
\hline \multicolumn{15}{|l|}{$\begin{array}{l}\text { Credit to nationals }{ }^{1} \text { for } \\
\text { construction of first }\end{array}$} \\
\hline Other credits & 29.0 & 24.0 & 22.0 & 20.0 & 18.0 & 17.0 & 15.0 & 14.5 & 14.0 & 13.0 & 12.5 & 12.0 & 18.0 & 18.0 \\
\hline \multicolumn{15}{|l|}{ Long-term credit ${ }^{2}$} \\
\hline $\begin{array}{l}\text { Credit to small and medium- } \\
\text { sized national enterprises }\end{array}$ & 29.0 & 24.0 & 22.0 & 20.0 & 18.0 & 17.0 & 15.0 & 14.5 & 14.0 & 13.0 & 12.5 & 12.0 & 18.0 & 18.0 \\
\hline \multicolumn{15}{|l|}{$\begin{array}{l}\text { Credit to nationals }{ }^{1} \text { for } \\
\text { construction of first }\end{array}$} \\
\hline primary residence & 29.0 & 24.0 & 22.0 & 20.0 & 18.0 & 17.0 & 15.0 & 14.5 & 14.0 & 13.0 & 12.5 & 12.0 & 18.0 & 18.0 \\
\hline Other credits & 29.0 & 24.0 & 22.0 & 20.0 & 18.0 & 17.0 & 15.0 & 14.5 & 14.0 & 13.0 & 12.5 & 12.0 & 18.0 & 18.0 \\
\hline
\end{tabular}

Source: Central Bank of West African States (BCEAO).

1 Of any member state of the West African Monetary Union (WAMU).

${ }^{2}$ With maturity of more than 2 years and less than 15 years. 
Table 32. Mali: Balance of Payments, 1994-99 ' 2

(In billions of CFA francs, unless otherwise indicated)

\begin{tabular}{|c|c|c|c|c|c|c|}
\hline & 1994 & 1995 & 1996 & 5997 & 1998 & $\begin{aligned} 1999 \\
\text { Est }\end{aligned}$ \\
\hline Exports, f.o.b. & 186.8 & 220.5 & 221.4 & 327.7 & 331.1 & 348.6 \\
\hline Of which: cotton (fiber) & 81.5 & 126.9 & 132.6 & 158.7 & 147.8 & 150.1 \\
\hline Imports, f.o.b. & .251 .2 & -272.1 & -282.1 & -318.6 & -329.3 & -364.6 \\
\hline Of which: petroleum & -209 & -30.8 & -37.3 & .44 .9 & -38.2 & .522 \\
\hline Trade balance & -64.3 & -51.6 & -60.7 & 9.1 & 1.8 & -16.0 \\
\hline Setvices (net) & -156.4 & +189.7 & .175 .4 & -187.9 & -190.0 & .196 .4 \\
\hline Of which: interest due ${ }^{3}$ & -21.9 & -16.2 & -13.9 & -13.2 & -11.2 & -13.5 \\
\hline Private transfers (net) & $4 \overline{7} .1$ & 47.8 & 46.0 & 42.6 & 40.7 & 42.4 \\
\hline Official transfers (net) & 134.4 & 111.4 & 124.1 & 96.3 & 100.8 & 92.9 \\
\hline of which: in kind & [3.1 & 5.5 & 6.1 & 4.1 & 4.1 & 4.1 \\
\hline budgetwry & 42.8 & 29.4 & 26.7 & 20.8 & 19.6 & 14.6 \\
\hline projeci-related & 55.0 & 63.0 & 69.8 & 63.4 & 70.3 & 68.8 \\
\hline \multicolumn{7}{|l|}{ Corrent account balance } \\
\hline Including oflicial transfers & -39.2 & .82 .1 & -66.0 & -39.1 & -46.7 & -77.0 \\
\hline Excluding official transfers & -173.6 & .193 .5 & -190.1 & -135.4 & -147.5 & -169.9 \\
\hline Noumanetary capital (net) & 45.7 & $\$ 1.1$ & 72.1 & 20.0 & 24.4 & 48.9 \\
\hline Privat= (nex) & 20.9 & 15.0 & 30.9 & -13.7 & -33.6 & $-\$ 1.4$ \\
\hline Official (net) & 24.8 & 46.1 & 412 & 33.7 & 58.0 & 60.3 \\
\hline Disbursements (act) & 91.7 & 110.1 & 102.1 & 72.7 & 83.9 & 91.7 \\
\hline Budgetary & 31.7 & 39.6 & 34.6 & 11.6 & 4.8 & 13.1 \\
\hline Project related & 60.0 & 70.5 & 67.5 & 61.1 & 79.1 & 78.6 \\
\hline Anortization due & -66.9 & $-64,0$ & -60.9 & -39.0 & -25.9 & -31.4 \\
\hline Debt relief ${ }^{4}$ & $5[.8$ & 44.8 & 41.0 & 0.7 & 0.0 & 0.0 \\
\hline Errors and omissions & 9.8 & 10.0 & 18.2 & -8.2 & +13.7 & -6.1 \\
\hline Overall balance & 68.1 & 33.8 & 65.3 & -26.5 & -36.0 & -34.2 \\
\hline Firlancing & -68.1 & -33.8 & -65.3 & 26.5 & 36.0 & 34.2 \\
\hline Forrigm assets (net) & -48.2 & -37.1 & 55.3 & 12.] & 36.0 & 37.2 \\
\hline Of which: IMF (uet) & 17.7 & 18.4 & $\mathbf{J 1 . 6}$ & 12.5 & 1.8 & 7,4 \\
\hline Revaluation adjusiment & 0.0 & 3.3 & 0.0 & 0.0 & 0.0 & $-3,0$ \\
\hline Debt uoder negotiation/moratorium & 0.0 & 0.0 & 0.0 & 14.6 & 0.0 & 0.0 \\
\hline Payments arreats & -19.8 & 0.0 & 0.0 & 0.0 & 0,0 & 0.0 \\
\hline Accumulation & 0.0 & 0.0 & 0.0 & 0.0 & 0.0 & 0.0 \\
\hline Reduction & -19.8 & 0.0 & 0.0 & 0.0 & 0.0 & 0.0 \\
\hline \multicolumn{7}{|l|}{ Memorandum items: } \\
\hline \multicolumn{7}{|l|}{$\begin{array}{l}\text { Extemal current account balance } \\
\text { as a percent of GDP }\end{array}$} \\
\hline Including official transfers & .3 .8 & -6.7 & -4.9 & -2.7 & -3.0 & -4.8 \\
\hline Excluding official transfers & .16 .9 &.$\$ 5.7$ & -14.2 & -9.4 & -9.5 & -10.6 \\
\hline $\begin{array}{l}\text { Outstanding payments arteats } \\
\text { (end of period) }\end{array}$ & 0.0 & 0.0 & 0.0 & 0.0 & 0.0 & 0.0 \\
\hline
\end{tabular}

Sources: Malian euthorities; and Fund staff estimaks.

${ }^{1}$ Data may not add up because of rounding.

${ }^{2}$ Incleding debt service dise to the People's Republic of China and Russia

${ }^{3}$ After debt cancellation obtaibed through 1996, including the 1994 cancellation of debt by France, Italy, and Switzerland, equivalent to CFAF 114.7 billion.

"Refiects agreemencs on debt rescheduling and moratoriums, as well as debt under negotiation.

${ }^{3}$ The end-of-period stock includes the net change in paymeats arears, as well ss the change in the value of the stock owing to exchange tate movements. 
Tabje 33. Mali: Balance of Payments, 1994-99' =

(In millions of SDRs, unless otherwise indicated)

\begin{tabular}{|c|c|c|c|c|c|c|}
\hline & 1994 & 1995 & 1996 & 1997 & 1998 & $\begin{array}{r}1999 \\
\text { Est. }\end{array}$ \\
\hline Exports, f.o.b. & 235.0 & 291.2 & 298.1 & 408.1 & 413.9 & 414,2 \\
\hline of which: cotton (fiber) & 102.5 & 167.6 & 178.5 & 197.6 & 184.7 & 178.4 \\
\hline Inqparts, f.o.b. & -315.9 & .359 .4 & -379.8 & -396.7 & -411.7 & -433.1 \\
\hline Of which: petroleurn & -26.3 & -40.7 & .50 .2 & .55 .9 & -47.8 & -62.0 \\
\hline Trade balance & -80.9 & -68.2 & -81.8 & 11.4 & 2.3 & -19.0 \\
\hline Services (net) & -196.7 & -250.5 & -236.1 & -233.9 & -237.5 & .233 .3 \\
\hline Of which: interest due ${ }^{3}$ & -27.5 & -21.4 & -18.7 & -16.4 & -13.9 & -16.0 \\
\hline Private transfers (net) & 59.2 & 63.1 & 61.9 & 54.0 & 50.9 & 50.4 \\
\hline Official transfers (net) & 169.0 & 147.1 & 167.] & 119.9 & 126.0 & 110.4 \\
\hline Of which: in kind & 16.5 & 7.3 & 8.2 & 5.1 & 5.1 & 4.9 \\
\hline budgetary & 53.8 & 38.8 & 35.9 & 25.9 & 24.5 & 17.3 \\
\hline project-rejated & 69.2 & 83.2 & 94.0 & 78.9 & 87.9 & 81.7 \\
\hline \multicolumn{7}{|l|}{ Crrrent account balance } \\
\hline Including official transfers & -49.3 & -108.5 & -88.9 & -48.6 & -58.4 & -91.5 \\
\hline Excluding official transfers & -218.4 & .255 .6 & -256.0 & -168.5 & -184.4 & -201.9 \\
\hline Nonmonetary capital (net) & 57.5 & 80.7 & 97.1 & 24.9 & 30.5 & 58.1 \\
\hline Private (net) & 26.3 & 19.8 & 41.6 & -17.1 & -42.0 & -13.5 \\
\hline Official (net) & 31.2 & 60.9 & 55.5 & 42.0 & 72.5 & 71.6 \\
\hline Disbursements (net) & 115.3 & 145.4 & 137.5 & 90.6 & 104.9 & 109.0 \\
\hline Budgetary & 39.9 & 52.3 & 46.6 & 14.5 & 6.0 & 15.6 \\
\hline Projiect telated & 75.5 & 93.1 & 90.9 & 76.1 & 98.9 & 93.4 \\
\hline Amortization due & -84.1 & -84.5 & -82.0 & -48.6 & -32.4 & -37.3 \\
\hline Debt relief ${ }^{4}$ & 65.2 & 59.2 & 55.2 & 0.9 & 0.0 & 0.0 \\
\hline Errors and omissions & 12.3 & 13.2 & 24.5 & -10.2 & -17.1 & -7.2 \\
\hline Overall balance & 85.7 & 44.6 & 87.9 & -33.0 & -45.0 & -40.7 \\
\hline Finarcing & -85.7 & -44.6 & -87.9 & 33.0 & 45.0 & 40.7 \\
\hline Foreign assets (net) & -60.6 & -49.0 & -87.9 & 15.1 & 45.0 & 44.2 \\
\hline Of which: (MF (net) & 22.3 & 24.3 & 15.7 & 15.6 & 2.3 & B.8 \\
\hline Revahuation adjustment & 0.0 & 4.4 & 0.0 & 0.0 & 0.0 & -3.6 \\
\hline Debt under negotiation/moratorium & 0.0 & 0.0 & 0.0 & 18.2 & 0.0 & 0.0 \\
\hline Payments arrears & $-24,9$ & 0.0 & 0.0 & 0.0 & 0.0 & 0.0 \\
\hline Accumblation & 0.0 & 0.0 & 0.0 & 0.0 & 0.0 & 0.0 \\
\hline Reduction & -24.9 & 0.0 & 0.0 & 0.0 & 0.0 & 0.0 \\
\hline \multicolumn{7}{|l|}{ Memorandum items: } \\
\hline \multicolumn{7}{|l|}{ Outstanding payments arrears } \\
\hline (end of period) ${ }^{5}$ & 0.0 & 0.0 & 0.0 & 0.0 & 0.0 & 0.0 \\
\hline \multicolumn{7}{|l|}{ Exchange rate } \\
\hline CFAF/SDR (period average) & 795.0 & 757.1 & 742.7 & 803.1 & 800.0 & 841.7 \\
\hline
\end{tabular}

Sources: Data pnovided by the Malian authorities; and Fund staff estimates.

' Data may not add up because of rounding.

2 Including debt service due to the People's Republic of China and Russia.

${ }^{3}$ After debt cancellation obtained fhrough 1997, including the 1994 cancellation of debt by France , Italy, and Swizzerland, equivalent to CFAF 114.7 billion.

4 Reflects agreements on debt rescheduling and moratoriums, as well as debt under negotiation.

s The end-of-period stock includes the net change in payments arrears, as well as the change in the value of the stock owing to exchange rate movements. 
Table 34. Mali: Composition of Expotts, f.o.b., 1994-99

(V'alues in billians of CFA francs, volumes in metric tons, and unit values in CFA francs per kilogrami)

\begin{tabular}{|c|c|c|c|c|c|c|}
\hline & 1994 & 1995 & 1996 & 1997 & 1998 & $\begin{array}{r}1999 \\
\text { Est }\end{array}$ \\
\hline \multicolumn{7}{|l|}{ Coltos } \\
\hline Vahe & 85.0 & 129.2 & 134.9 & 161.2 & 150.5 & 153.0 \\
\hline \multicolumn{7}{|l|}{ Cotton fiber } \\
\hline Value & 81.5 & 125.9 & 132,6 & 158.7 & 147.8 & 150.1 \\
\hline Volume & 109.272 .7 & $148,122.8$ & $161,053.4$ & $209,152,4$ & $178,032.0$ & $221,761.0$ \\
\hline Unit value & 729.5 & 856.8 & 823.3 & 781.0 & 830.0 & 677.0 \\
\hline \multicolumn{7}{|l|}{ Cotton cakes } \\
\hline Value & 0.5 & 0.5 & 0.5 & 0.5 & 0.6 & 0.6 \\
\hline Volumo & $10,500.0$ & $11,025,0$ & $11,168,3$ & $11,615.0$ & $13,000.0$ & $13,520,0$ \\
\hline Linit value & 48.0 & 43.1 & 44.2 & 44.0 & 45,4 & 45.1 \\
\hline \multicolumn{7}{|l|}{ Cotton threads and materials } \\
\hline Value & 2.2 & 1.1 & 1.1 & 1.2 & 1.3 & 1.3 \\
\hline Volume & $2,700.0$ & 1,3720 & $1,398.0$ & $1,458.0$ & $1,516.3$ & $1,577.0$ \\
\hline Unit value & 825.0 & 802.2 & 811,0 & B3I.0 & 858.1 & 850.8 \\
\hline \multicolumn{7}{|l|}{ Cottonseed oil } \\
\hline Value & 0.8 & $0 . T$ & 0.7 & 0.8 & 0.9 & 0.5 \\
\hline Volume & $3,100.0$ & $3,131,0$ & $3,149.8$ & $3,276.0$ & $3,500.0$ & $3,640.0$ \\
\hline Unit value & 255.0 & 229.2 & 229.0 & 242.0 & 249.9 & 247.8 \\
\hline \multicolumn{7}{|l|}{ Livestock } \\
\hline Value & 51.8 & 40.0 & 30.0 & 31.3 & 28.1 & 33.0 \\
\hline Volune & $49,700.0$ & $37,582.0$ & $28,599.0$ & $29,464.0$ & $24,490.0$ & $27,651.0$ \\
\hline Unit value & $1,184.3$ & $1,064.6$ & $1,049.0$ & $1,062.0$ & $1,147.0$ & $1,192.0$ \\
\hline \multicolumn{7}{|l|}{ Hides and leathers. } \\
\hline Vahue & 2.9 & 1.6 & 2.6 & 3.1 & 3.2 & 3.4 \\
\hline Volutine & $2,725.0$ & $1,672,0$ & $2,861,0$ & $2,976.0$ & $3,124.8$ & $3,281.0$ \\
\hline Unit value & $1,053,0$ & 957.5 & 925.0 & $1,032.0$ & $1,032.0$ & 1.036 .0 \\
\hline \multicolumn{7}{|l|}{ Fish } \\
\hline Value & 1.7 & 0.8 & 0.9 & 0.9 & 1.0 & 1.0 \\
\hline Volume & $1,750.0$ & 802.0 & 870.0 & 896.1 & 876.0 & 902.3 \\
\hline Unit value & 950.0 & 997.5 & 998.0 & $1,050.4$ & $1,084.7$ & $1,075.0$ \\
\hline \multicolumn{7}{|l|}{ Shelled groundnuts } \\
\hline Vahe & 0.4 & 0.2 & 0.3 & 0.2 & 0.2 & 0.2 \\
\hline Volume & $3,941.7$ & $1,754.0$ & $2,350.0$ & 1,8160 & 1,8520 & $1,890.0$ \\
\hline Unit value & 113.0 & 113.0 & 113.0 & 116.0 & 119.0 & 119.0 \\
\hline \multicolumn{7}{|l|}{ Other oilseeds } \\
\hline Value & 3.0 & 0.1 & 0.3 & 0.3 & 0.3 & 0.3 \\
\hline Vohune & $21,500.0$ & 714,0 & $2,142.0$ & $1,850,0$ & $1,868.5$ & $1,887.2$ \\
\hline Unit value & 140.0 & 140.0 & 140.0 & 148.0 & 153.0 & 152.0 \\
\hline \multicolumn{7}{|l|}{ Gold } \\
\hline Valure & 27.8 & 35.6 & 39.8 & 117.2 & 133. I & 142.4 \\
\hline Vohme & 4.6 & 6.2 & 6.6 & 18.5 & 22.8 & 25.3 \\
\hline Unit value & $6,036,303.0$ & $5,776,600,0$ & $6,037,782.3$ & $6,340,359.6$ & $5,831,535.5$ & $5,620,027.3$ \\
\hline \multicolumn{7}{|l|}{ Other } \\
\hline Value & 14.3 & 13.0 & 12.6 & 13.6 & 14.7 & 15.3 \\
\hline Total & 186.8 & 220.5 & 221.4 & 327.7 & 331.1 & 348.6 \\
\hline \multicolumn{7}{|l|}{ Memorandum itenr: } \\
\hline \multicolumn{7}{|l|}{ Three principal exports as } \\
\hline a percentage of toril exports & 88.1 & 92.9 & 92.5 & 94.5 & 94.2 & 94.2 \\
\hline
\end{tabular}

Sources: Cestral Bank of West African States (BCEAD); and Fund staff estimates. 
Table 35. Mali: Conaposidion of Imparts, c i.f., 1994-99

(Values in billions of CFA franes, volumes in metric toms, and unit values in CFA franss per kilogram)

\begin{tabular}{|c|c|c|c|c|c|c|}
\hline & 1904 & 1995 & 1996 & 1997 & 1998 & $\begin{array}{r}1999 \\
\text { Est. }\end{array}$ \\
\hline \multicolumn{7}{|l|}{ Foodstuffs } \\
\hline Vahue & 47.8 & 55.4 & 53.0 & 64.7 & 72.8 & $6 B .9$ \\
\hline \multicolumn{7}{|l|}{ Cereals } \\
\hline Valut & 7.2 & 10.9 & 12.8 & 12.2 & 17.8 & 15.3 \\
\hline Vodume & $35,100.0$ & $49,840.0$ & $5 B, 528.0$ & $59,500.0$ & $84,600.0$ & 78,9950 \\
\hline Unit value & 205.0 & 2187 & 218.7 & 205.5 & 210.0 & 198.9 \\
\hline \multicolumn{7}{|l|}{ Suggr } \\
\hline Value & 15.2 & 16.8 & 12.2 & 17.6 & 17.1 & 16.9 \\
\hline Volume & $51,000.0$ & $56,950,0=$ & $63,0 \mathrm{d2.6}$ & $62,857.1$ & $70,715.0$ & $75,989.0$ \\
\hline Unit value & 298.2 & 295.0 & 272.8 & 280.0 & 241.2 & 221.8 \\
\hline \multicolumn{7}{|l|}{ Milk } \\
\hline Vajue & 10.1 & 11.9 & 9.9 & 12.2 & 12.7 & 13.5 \\
\hline Volume & $8,938]$. & $10,258.6$ & $8,497.9$ & $9,363.0$ & $9,458.6$ & $11,465.0$ \\
\hline Utuit value & & 1,1300 & $1,165.0$ & $1,303.0$ & $1,345.5$ & $1,348.0$ \\
\hline \multicolumn{7}{|l|}{ Tes and coffee } \\
\hline Value & 3.1 & 2.7 & 5.0 & B. 2 & 11.5 & 8.3 \\
\hline Volume & $1,611.0$ & $1,641.3$ & $3,594,5$ & $4,900.0$ & $6,850.0$ & 4,9990 \\
\hline Uhit value & $1,930.0$ & $1,645.0$ & $1,391.0$ & $1,670.0$ & $1,675.0$ & $1,652.0$ \\
\hline \multicolumn{7}{|c|}{ Other beverages } \\
\hline Yalue & 0.8 & 0.7 & 0.8 & 09 & 0.9 & 1.2 \\
\hline Volvene & $2,546.2$ & $2,622.3$ & $2,701.0$ & $2,782.0$ & $2,837.6$ & $3,681,0$ \\
\hline Unit value & 296.0 & 266.1 & 292.0 & 3060 & 316.0 & 317.0 \\
\hline \multicolumn{7}{|l|}{ Cola nuts } \\
\hline Value & 1.6 & 1.5 & 1.6 & 18 & 1.9 & 2.3 \\
\hline Volutne & $7,906,0$ & $8,222.2$ & $8,551.1$ & $8,721.0$ & $8,941,1$ & $9,925.0$ \\
\hline Unit velue & 205.0 & 184.3 & 190.0 & 202.0 & 208.6 & 205.8 \\
\hline \multicolumn{7}{|l|}{ Ocher } \\
\hline Valise & 9.8 & 10.9 & 10.7 & 11.9 & 11.0 & 9.4 \\
\hline Volurate & $29,599.1$ & $30,783.1$ & $31,706.6$ & $32,568.0$ & $32,894.0$ & $28,468.0$ \\
\hline Unit value & 331.9 & 354.0 & 338.0 & 364.0 & 335.8 & 329.6 \\
\hline \multicolumn{7}{|c|}{ Machines and vethicles } \\
\hline Value & 107.0 & 123.0 & 115.4 & 125.2 & 128.3 & 154.1 \\
\hline Volurne & $30,300.0$ & $35,000.0$ & $32,190,0$ & $34,390.0$ & $34,734.0$ & $40,951.0$ \\
\hline Uait value & $3,531.0$ & $3,513.0$ & $3,585.8$ & $3,640.0$ & $3,694.6$ & $3,761.9$ \\
\hline \multicolumn{7}{|c|}{ Petroleum products } \\
\hline Valte & 29.1 & 42.4 & 52.2 & 61.1 & 52.6 & 71.0 \\
\hline Volutine & $226,004.0$ & $289,905.0$ & $332,843.0$ & $400,164.0$ & $439,243.0$ & $471,925.0$ \\
\hline Unit value & 128.9 & 146.3 & 156.8 & 152.6 & 119.7 & 150.5 \\
\hline \multicolumn{7}{|c|}{ Construction materials } \\
\hline Value & 33.7 & 39.4 & 39.8 & 47.1 & 50.7 & 51.9 \\
\hline Volume & $34,474.0$ & $40,000.0$ & $41,000.0$ & $43,473.0$ & $44,950.0$ & 45,7140 \\
\hline Uni1 value & 976.4 & 985.0 & 970.0 & $1,083.0$ & $1,129.0$ & 1,1360 \\
\hline \multicolumn{7}{|c|}{ Cbenical producls } \\
\hline Value & 33.9 & 35.2 & $36 . \mathrm{B}$ & 39.2 & 43.3 & 50.4 \\
\hline Volume & $74,077.0$ & $77,780.0$ & BI,2BI.0 & $84,126.0$ & $87,650.0$ & 95,9770 \\
\hline Unit value & $\$ 57.2$ & 453.0 & 453.0 & 466.0 & 494.0 & 5250 \\
\hline \multicolumn{7}{|c|}{ Textiles and leather } \\
\hline Value & 22.5 & 21.7 & 23.3 & 23.7 & 26.6 & 22.4 \\
\hline Volume & $21,854.5$ & $2 z, 510.2$ & $23,410.6$ & 23.700 .0 & $24,174.0$ & 22,4220 \\
\hline Unit value & $1,029.7$ & 965.0 & 995.0 & 9980 & 1,1018 & $1,000 \mathrm{~B}$ \\
\hline \multicolumn{7}{|l|}{ Other } \\
\hline Value & 75.4 & 57.7 & 69.6 & 72.6 & 742 & $\pi .3$ \\
\hline Total & 349.3 & 374.8 & 395.1 & 433.5 & 448.6 & 496.0 \\
\hline
\end{tabular}

Sources: Central Bank of West African States (BCEAO), and Find sinff extimates. 
Table 36. Mali: Direction of Trade, 1994-99

(Th millions orfJ.s. dollars)

\begin{tabular}{|c|c|c|c|c|c|c|c|c|c|c|c|c|}
\hline & \multicolumn{2}{|c|}{1994} & \multicolumn{2}{|c|}{1995} & \multicolumn{2}{|c|}{1996} & \multicolumn{2}{|c|}{1997} & \multicolumn{2}{|c|}{ L998 } & \multicolumn{2}{|c|}{1999} \\
\hline & Value & Percent & Value & Percent & Value & Percent & Value & Peacent & Value & Percent & $\begin{array}{l}\text { Value } \\
\text { Est. }\end{array}$ & $\begin{array}{l}\text { Percent } \\
\text { Est. }\end{array}$ \\
\hline Exports & 175.26 & 100.00 & 237.1 & 100,0 & 282.8 & 100.0 & 269.9 & 100.0 & 288.8 & 100,0 & 332.3 & 100.0 \\
\hline $\begin{array}{l}\text { Industrial couvtries } \\
\text { of whisch: }\end{array}$ & 97.06 & 5538 & $9 \$ .9$ & 38.8 & 105.1 & 37.1 & 103.0 & 38.2 & 121.2 & 44.9 & 175.0 & 52.7 \\
\hline Belgium-Luxemboury & 25.96 & 14.81 & 17.8 & 7.5 & 12.4 & 4.4 & 6.4 & 2.2 & 6.6 & 2.3 & 9.1 & 2.7 \\
\hline France & 7.38 & 4.21 & 6.9 & 2.9 & 4.9 & 1.7 & 7.0 & 2.5 & 4.6 & 1.6 & 4.3 & 1.3 \\
\hline Germeny & 3.84 & 2.19 & 3.7 & 1.6 & 2.9 & 1.0 & 3.8 & 1.4 & 4.7 & 1.7 & 4.3 & 1.3 \\
\hline Spain & 4.48 & 2.56 & 7.8 & 3.3 & 7.8 & 2.8 & 7.2 & 2.7 & 7.6 & 2.7 & 5.8 & 1.7 \\
\hline Uniled Kingdon & 0.66 & 0.38 & 0.3 & 0.1 & 1.0 & 0.3 & 0.9 & 03 & 0.7 & 0.2 & 4.1 & 1.2 \\
\hline Developing countries & 75.46 & 43.06 & 142.2 & 60.0 & 174.2 & 61.6 & 163.1 & 60.4 & 163.2 & 57.7 & 152.6 & 45.9 \\
\hline Africa & 15.95 & 9.10 & 20.4 & 8.6 & 28.4 & 10.1 & 21.8 & 8.1 & 29,9 & 13.1 & 28.0 & 8.4 \\
\hline Of whlch: Côte dTlvoire & 2.07 & 0.18 & 2.9 & 1.2 & 4.2 & 1.5 & 2.8 & 1.1 & 1.9 & 0.7 & 2.0 & 0.6 \\
\hline Asia & 45.83 & 26.85 & 98.1 & $4 \mathrm{E} .4$ & 137.5 & 48.6 & 122.3 & 45.3 & 103.2 & 38.2 & 112.8 & 33.9 \\
\hline \multicolumn{13}{|l|}{ of which: People's } \\
\hline Republic of China ${ }^{2}$ & 8.27 & 4.72 & 33.1 & 13.9 & 12.4 & 4.4 & 25.2 & 9.3 & 5.1 & 1.9 & 4.0 & 1.2 \\
\hline Others $^{3}$ & 13.68 & 7.81 & 23.6 & 10.0 & 8.3 & 3.0 & 18.9 & 6.7 & 30.1 & 11.2 & 11.8 & 3.5 \\
\hline Imports & 710.6 & 100.00 & 988.5 & 100.0 & $1,121.0$ & 100.0 & $1,136.5$ & 100.0 & $1,2.33 .0$ & 100.0 & $1,306.6$ & 100.0 \\
\hline lodustial coungres & 245.91 & 34.61 & 393.1 & 39.8 & 429.9 & 38.4 & 431.5 & 38.0 & 455.4 & 36.9 & 478.1 & 36.6 \\
\hline $\begin{array}{l}\text { Of which: } \\
\text { Belgium-Luxentbourg }\end{array}$ & 33.15 & 4.67 & 33.8 & 3.4 & 33.9 & 30 & 49.4 & 4.3 & 52.8 & 4.3 & 33.5 & 2.6 \\
\hline Prance & 105.14 & 34.80 & 191.5 & 19.4 & 218.8 & 19.5 & 199.4 & 27.5 & 220.8 & 19.4 & 243.8 & 18.7 \\
\hline Germany & 15.94 & 2.24 & 17.0 & 1.7 & 26.8 & 2.4 & 21.7 & 1.9 & 28.1 & 2.3 & 34.9 & 2.7 \\
\hline Sprie & 6.09 & 0.86 & 12.4 & 1.3 & 15.5 & 1.4 & 17.5 & 1.5 & 22.1 & 1.8 & 23.9 & 1.8 \\
\hline Unites Kiagdom & 18.27 & 2.57 & 41.7 & 4.2 & 41.7 & 3.7 & 43.3 & 3.8 & 29.3 & 2.4 & 28.4 & 2.2 \\
\hline Developing cormtries & 425,00 & 59.81 & 550.2 & 55.7 & 638.3 & 56.9 & 646,9 & 56.9 & 711.3 & 57.7 & 758.4 & 58.0 \\
\hline Affica & 361,86 & 50.92 & 449.8 & 45.5 & 540.6 & 48.2 & 570.6 & 50.2 & 615.6 & 49.9 & $6 \$ 2.2$ & 49.9 \\
\hline Of which: coste d'Ivoire & 112.69 & 16.70 & 160.2 & 16.8 & 202.5 & 18.1 & 222.1 & 99.5 & 233.6 & 18.9 & 246.9 & 18.9 \\
\hline $\begin{array}{l}\text { Asis } \\
\text { Of which. Peonle's }\end{array}$ & 53.45 & 7.52 & 32.1 & 8.3 & 778 & 6.9 & 54.7 & 4.8 & 76.4 & 6.2 & 80.2 & 6.3 \\
\hline $\begin{array}{l}\text { Of which: People's } \\
\text { Repubtic of China }\end{array}$ & 11.89 & 1.67 & 56.9 & \multicolumn{4}{|c|}{ Of which: People's } & 3.3 & $54 x$ & 4.4 & 57,6 & 4.4 \\
\hline Others $^{\prime}$ & 9.69 & 1.36 & 18.3 & 1.8 & 19.9 & 1.8 & 21.5 & 1.9 & 193 & 1.6 & 26.0 & 2.0 \\
\hline \multicolumn{13}{|l|}{ Memtraandum items: } \\
\hline \multicolumn{13}{|l|}{ Share of total trade } \\
\hline Prance & 112.52 & 12.70 & 198.4 & 16.2 & 223.7 & 15.9 & 206.5 & 14.7 & 204.1 & 13.4 & 225.1 & 13.7 \\
\hline Cołte d'Iveire & 232.39 & 26.23 & 169.1 & 13.8 & 206.7 & 14.7 & 225.0 & 16.0 & 235.5 & 15.5 & 248.9 & 15.2 \\
\hline Germany & 19.78 & 2.23 & 20.7 & 1.7 & 29.7 & 2.1 & 25.5 & 1.8 & 32.8 & 2.2 & 39.2 & 2.4 \\
\hline
\end{tabular}

Source: IMP, Direction of Trade Satistics dẹtabasc, March, 2000.

Datu may not add up beceuse of tounding.

Itcluding the maintand, Hong Kong SAR, and Macao SAR

"Iteluding the former U.S.S.R., Eastern Europeas countrits, whd others. 
Table 37. Mali: Terms of Trade Indices, 1994-99

(Index: 1985=100)

\begin{tabular}{|c|c|c|c|c|c|c|}
\hline & 1994 & 1995 & 1996 & 1997 & 1998 & $\begin{array}{r}1999 \\
\text { Est. }\end{array}$ \\
\hline \multicolumn{7}{|l|}{ Export indices } \\
\hline Value & 236.2 & 278.7 & 279.8 & 414.3 & 418.5 & 440.6 \\
\hline Volume & 170.3 & 198.6 & 202.9 & 303.1 & 300.3 & 344.1 \\
\hline Unit value & 138.7 & 140.4 & 137.9 & 136.7 & 139.4 & 128.1 \\
\hline \multicolumn{7}{|l|}{ Import indices } \\
\hline Value & 165.7 & 177.8 & 181.6 & 205.0 & 211.9 & 234.6 \\
\hline Volume & 94.4 & 101.3 & 104.0 & 118.3 & 124.7 & 134,0 \\
\hline Unit value $^{1}$ & 175.4 & 175.5 & 174.6 & 173.4 & 169.9 & 175.1 \\
\hline Terms of trade & 79.0 & 80.0 & 79.0 & 78.8 & 82.0 & 73.1 \\
\hline
\end{tabular}

Sources: Malian authorities; and Fund staff estimates.

${ }^{1}$ Unit value indices for exports and imports are Fisher indices calculated in terms of CFA francs. 
Table 38. Mali: Foreign Aid, 1994-99 ${ }^{1}$

(In billions of CFA francs, unless otherwise indicated)

\begin{tabular}{|c|c|c|c|c|c|c|}
\hline & 1994 & 1995 & 1996 & 1997 & 1998 & $\begin{array}{r}1999 \\
\text { Est. }\end{array}$ \\
\hline Total foreign aid & 226.1 & 221.5 & 226.2 & 169.0 & 183,6 & 194.7 \\
\hline Grants & 134.4 & 111.4 & 124.1 & 96.3 & 99.7 & 103.0 \\
\hline Loans & 91.7 & 110.1 & 102.1 & 72.7 & 83.9 & 91.7 \\
\hline Project aid & 115.0 & 133.5 & 137.3 & 124.5 & 149.4 & 147.4 \\
\hline Grants & 55.0 & 63.0 & 69.8 & 63.4 & 70.3 & 68.8 \\
\hline Loans & 60.0 & 70.5 & 67.5 & 61.1 & 79.1 & 78.6 \\
\hline Budgetary aid ${ }^{2}$ & 74.5 & 69.0 & 61.3 & 32.4 & 24.4 & 27.7 \\
\hline Grants & 42.8 & 29.4 & 26.7 & 20.8 & 19.6 & 14.6 \\
\hline Loans & 31.7 & 39.6 & 34.6 & 11.6 & 4.8 & 13.1 \\
\hline Aid in kind (grants) & 13.1 & 5.5 & 6.1 & 4.1 & 4.1 & 4.1 \\
\hline Of which: cereal & 2.4 & 1.7 & $\cdots$ & $\cdots$ & $\cdots$ & $\cdots$ \\
\hline \multicolumn{7}{|l|}{ Technical assistance } \\
\hline (Grants) & 23.5 & 13.5 & 21.5 & 8.0 & 5.7 & 15.5 \\
\hline \multicolumn{7}{|l|}{ Memorandum items: } \\
\hline \multicolumn{7}{|c|}{$\begin{array}{l}\text { Percent of total foreign } \\
\text { assistance in the form of: }\end{array}$} \\
\hline Grants & 59.4 & 50.3 & 54.9 & 57.0 & 54.3 & 52.9 \\
\hline Loans & 40.6 & 49.7 & 45.1 & 43.0 & 45.7 & 47.1 \\
\hline
\end{tabular}

Sources: Malian authorities; and Fund staff estimates.

${ }^{1}$ In the balance of payments, grants are included under official transfers; loans are included in nonmonetary capital receipts.

${ }^{2}$ Includes budgetary aid channeled both through the treasury and outside the treasury. 
Table 39. Mali: Extenal Disbused Public Debe Dutstanding by Credixar, 1994-99'

\begin{tabular}{|c|c|c|c|c|c|c|}
\hline & 1994 & 1995 & 1996 & 1997 & 1998 & $\begin{array}{c}1999 \\
\text { Ent. }\end{array}$ \\
\hline & \multicolumn{6}{|c|}{$\begin{array}{l}\text { (m millions of U.S, dolitars, wriess } \\
\text { othrowise indicated; end of period) }\end{array}$} \\
\hline Suppliters' crodits & 0.0 & 0.0 & 0.0 & 0.0 & 0.0 & 0.0 \\
\hline Germazay & 0.0 & a. 0 & 0.0 & 0.0 & 0.0 & 0.0 \\
\hline United Kingdom & 0.0 & 0.0 & 0.0 & 0.0 & 0.0 & 0.0 \\
\hline Financial institurtions ${ }^{2}$ & 2.1 & 2.3 & 0.0 & 0.0 & 6.4 & 9.7 \\
\hline Necherlands & 2.1 & 23 & 0.0 & 0.0 & 0.0 & 0.0 \\
\hline Multiple Iendets & a.o & 0.0 & 0.0 & 0.0 & 0.0 & 0.0 \\
\hline Switzerland & 0.0 & 0.0 & 0.0 & 0.0 & 0.0 & 0.0 \\
\hline Unitsd Kjogdom & 0.0 & 0.0 & 0.0 & 0.0 & 0.0 & 0.0 \\
\hline Multilaterai J Jans & $\mathrm{l}, 252.8$ & $1,399.1$ & 1.477 .6 & 1.498 .9 & $2,602.7$ & $1,618.3$ \\
\hline African Development Bank & 9.7 & 8.5 & 112 & 80 & 7.2 & 5.9 \\
\hline Africion Development Fund & 285.3 & 333.5 & 359.6 & 339.4 & 378.8 & 385.7 \\
\hline Arab Bank for Economic Devejoprnent in Africa & 17.1 & 16.4 & 12.3 & 11.2 & 12.2 & 9.6 \\
\hline European Economic Community & 8.4 & 5.8 & 8.4 & 7.5 & 7.8 & 6.8 \\
\hline European Development Fusd & 27.1 & 28,4 & 26.5 & 22.8 & 23.7 & 19.7 \\
\hline Europeas Imvestment Bark & 29.7 & 35.0 & 33.7 & 31.4 & 35.1 & 27.7 \\
\hline Imemational Fund for Agricultural Developgurent & 37.6 & 39.0 & A2.9 & 43.8 & 48.3 & 49.7 \\
\hline IDA & 769.6 & 863.0 & 915.2 & 935.3 & $1,010.7$ & $1,0,0,8$ \\
\hline Islamic Devetopment Bank & 32.6 & 31.6 & 32.3 & 35.7 & 35.8 & 34.8 \\
\hline League of Arab States & 3.8 & 3.1 & 1.3 & 0.8 & 0.5 & 0.5 \\
\hline OPEC Special Fund & 26.4 & 23.3 & 21.4 & 180 & 17.2 & 14.5 \\
\hline West African Developanent Bank & 0.0 & 3.2 & $\mathbf{8 . 0}$ & 30.2 & 21.5 & 25.4 \\
\hline African Solidarity Fund & 2.5 & 2.5 & 2.5 & 200 & 2.4 & 1.8 \\
\hline Economic Conrmunity of Wesi African States & 3.0 & 2.7 & 23 & 1.9 & 1.6 & 5.8 \\
\hline Bilatral loans & 1.250 .2 & $1,297.7$ & $1,266.7$ & $1,219,5$ & $1,272.1$ & $1,216 \mathrm{l}$ \\
\hline Algeria & 22.6 & 20.5 & 18.2 & 15.9 & 13.7 & 11.5 \\
\hline Switzerland & 0.0 & 0.0 & 0.0 & 00 & 0.0 & 0.0 \\
\hline Chne, People's Republic of & 117.4 & 137.3 & 139.3 & 135.9 & 141.0 & 193.7 \\
\hline Cóne d'ivoire & 0.0 & 8.0 & 7.5 & 2.2 & 2.3 & 2.3 \\
\hline Egypt, Arab Republic of & 3.6 & 3.6 & 0 & 0.0 & 0.0 & 0.0 \\
\hline Framee & 203.0 & 318.6 & 288.1 & 283.4 & 321.0 & 278.4 \\
\hline Iray & 20.0 & 20.0 & 20.0 & 20.0 & 25.0 & 25.0 \\
\hline Italy & 2.8 & 2.7 & 1.3 & 1.1 & 1.2 & 1.0 \\
\hline Japari & 47.6 & 64.1 & $B 0.8$ & 71.8 & 80.4 & 38.6 \\
\hline Kuwart & 35.9 & 35.2 & 35.0 & 33.1 & 32.4 & 34.1 \\
\hline Libya & 7.2 & 7.2 & 6.0 & 4. & 4.2 & 3.1 \\
\hline Wetherlands & 5.0 & 5.4 & 2.5 & 2.1 & 2.3 & 2.0 \\
\hline Saudi Arabia & 96.7 & 84.6 & 78.6 & 73.4 & 71.0 & 66.7 \\
\hline Unived Arab Emisates & 33.5 & 26.1 & 236 & 21.4 & 19.6 & 16.1 \\
\hline Uniled Kingdom & 16.7 & 16.6 & 18.0 & 6.7 & 6.7 & 6.7 \\
\hline R.ussia & 549.3 & 547.6 & 547.6 & 547,6 & 544.8 & 544.6 \\
\hline Subrota] & $2,505.1$ & $2,699.0$ & $2,744.3$ & $2,70 \mathrm{~B} .3$ & $2,874.7$ & $2,844.6$ \\
\hline Use of IMF resources & $10 B .2$ & 147.1 & 104.8 & 175.7 & 186.5 & 193.4 \\
\hline Total & $2,6,13.3$ & $2,846 . \mathrm{J}$ & 2909.1 & $2,884.0$ & $3,061.2$ & $3,038.0$ \\
\hline Memorandum iterns: & \multicolumn{6}{|c|}{ (In percent of total debt stack, unless othervise indicated) } \\
\hline Suppli=xz & 0.0 & 0.0 & 0.0 & 0.0 & 8.0 & 0.0 \\
\hline Finaneial instibutions & 0.1 & 0.1 & 0.0 & 0.0 & 0.2 & 0.3 \\
\hline \multicolumn{7}{|l|}{ Multilaterai loans including } \\
\hline IMF Trust Fuad & 45.1 & 54.2 & 56.5 & 57.7 & 58.4 & 39.7 \\
\hline Bilateral loans & 47.8 & 45.6 & 43.5 & 42.3 & 41.6 & 40.0 \\
\hline China, Pecple's Republic of & 4.5 & 4.8 & 4.8 & 4.7 & 4.6 & 4.4 \\
\hline France & 11.2 & 112 & 90 & 9.8 & 10.5 & 9.2 \\
\hline Rnssil & 21.0 & 59.2 & $18 . \mathrm{B}$ & 19.0 & 19.8 & 17.9 \\
\hline MNF & 4.0 & 5.2 & 5.7 & 6.1 & 6.1 & 6.4 \\
\hline Exchange rate: CFAF $\pi$ Ss, doliar ${ }^{3}$ & 534.6 & 490.0 & 523.7 & 598.9 & 5622 & 653.0 \\
\hline
\end{tabular}

Sources: IBRD, Debtor Reporting System; MF, Indetrational Firancial Statistice; and Maljem authorities.

'Dan may not add up because of rounding.

2 Includes export credits.

3 End of period. 
Table 40. Mali: Structure and Terms of New Loan Commitments, $1994-99$

(In millions of U.S. dollars, unless otherwise specified)

\begin{tabular}{|c|c|c|c|c|c|c|}
\hline & 1994 & 1995 & 1996 & 1997 & 1998 & 1999 \\
\hline \multicolumn{7}{|l|}{ Category of lender } \\
\hline Bilateral loans & 5.8 & 61.9 & 7.7 & 0.0 & 22.8 & 42.1 \\
\hline MuItilateral loans & 129.0 & 100.7 & 230.4 & 123.4 & 90.9 & 202.7 \\
\hline Suppliers' credits & 0.0 & 0.0 & 0.0 & 0.0 & 0.0 & 0.0 \\
\hline Financial institutions & 0.0 & 0.0 & 0.0 & 0.0 & 0.0 & 6.4 \\
\hline Total & 134.8 & 162.6 & 238.1 & 123.4 & 113.8 & 251.2 \\
\hline \multicolumn{7}{|l|}{ Average terms } \\
\hline Interest rate (percent) & 0.8 & 1.5 & 1.3 & 0.9 & 1.7 & 2.0 \\
\hline Maturity (years) & 37.1 & 30.7 & 35.9 & 43.8 & 24.5 & 24.2 \\
\hline Grace period (years) & 9.7 & 8.8 & 9,3 & 9.9 & 7.0 & 3.4 \\
\hline Grant element (percent) & 77.7 & 68.6 & 73.3 & 79.7 & 65.8 & 58.1 \\
\hline
\end{tabular}

Sources: IBRD, Debtor Reporting System; Malian authorities; and Fund and World Bank staff estimates. 
Table 41. Mali: Debt Service on Medium- and Long-Term External Public Debt, $199499^{1}$

\begin{tabular}{|c|c|c|c|c|c|c|}
\hline & 1994 & 1995 & 1996 & 1997 & 1998 & 1999 \\
\hline & \multicolumn{6}{|c|}{ (In billions of CFA francs) } \\
\hline IMF & 6.2 & 4.5 & 4.9 & 4.7 & 7.4 & 7.6 \\
\hline Charges and interest & 0.8 & 0.9 & 0.9 & 0.6 & 1.0 & 1.0 \\
\hline Repurchases and repayments & 5.4 & 3.6 & 4.0 & 4.1 & 6.4 & 6.6 \\
\hline \multicolumn{7}{|l|}{ Scheduled debt service } \\
\hline (excluding IMF) & 45.4 & 38.7 & 34.9 & 36.8 & 36.1 & 43.9 \\
\hline Interest & 18.2 & 13.0 & 11.6 & 11.9 & 10.2 & 12.5 \\
\hline Principal & 27.2 & 25.7 & 23.3 & 25.0 & 25.9 & 31,4 \\
\hline \multicolumn{7}{|l|}{ Schedufed debt service } \\
\hline (including IMF) & 51.6 & 42.8 & 39.8 & 41.6 & 43.5 & 51.5 \\
\hline Interest & 19.0 & 13.9 & 12.5 & 12.5 & 11.2 & 13.5 \\
\hline Principal (excluding IMF) & 27.2 & 25.3 & 23.3 & 25.0 & 25.9 & 31.4 \\
\hline \multirow[t]{2}{*}{ Repurchases to IMF } & 5.4 & 3.6 & 4.0 & 4.1 & 6.4 & 6.6 \\
\hline & \multicolumn{6}{|c|}{$\begin{array}{l}\text { (In percent of exports of goods } \\
\text { and nonfactor services) }\end{array}$} \\
\hline Debt-service ratio vis-à-vis the IMF & 2.8 & 1.7 & 1.9 & 1.3 & 1.9 & 1.9 \\
\hline \multicolumn{7}{|l|}{ Debt-service ratio } \\
\hline (including IMF) & 22.9 & 16.4 & 15,1 & 11.1 & 11.4 & 12.9 \\
\hline Interest & 8.4 & 5.3 & 4.7 & 3.3 & 2.9 & 3.4 \\
\hline \multirow[t]{2}{*}{ Principal } & 14.5 & 11.1 & 10.4 & 7.8 & 8.5 & 9.5 \\
\hline & \multicolumn{6}{|c|}{ (In billions of CFA francs) } \\
\hline Debt rescheduling ${ }^{2}$ & 7.1 & 2.3 & 2.0 & 0.0 & 0.0 & 0.0 \\
\hline Debt cancellation & 2.3 & 2.0 & 0.0 & 0.0 & 0.0 & 0.0 \\
\hline Exports of goods and nonfactor services & 225.1 & 259.9 & 262,9 & 375.6 & 380.2 & 400.4 \\
\hline
\end{tabular}

Sources: Malian authorities; and Fund staff estimates.

${ }^{1}$ Data may not add up because of rounding.

${ }^{2}$ On current debt-service obligations. 
Table 42. Mali: Nominal and Real Effective Exchange Rate Indices, 1994-99'

(Index: 1990=100)

\begin{tabular}{|c|c|c|}
\hline & Nominal & Real \\
\hline \multicolumn{3}{|l|}{1994} \\
\hline First quarter & 52.76 & 50.85 \\
\hline Second quarter & 52.98 & 53.14 \\
\hline Third quarter & 53.97 & 57.12 \\
\hline Fourth quarter & 54.03 & 57.45 \\
\hline \multicolumn{3}{|l|}{1995} \\
\hline First quarter & 54.62 & 58.41 \\
\hline Second quarter & 55.27 & 60.79 \\
\hline Third quarter & 55.51 & 62.12 \\
\hline Fourth quarter & 55.78 & 64.22 \\
\hline \multicolumn{3}{|l|}{1996} \\
\hline First quarter & 55.51 & 63.74 \\
\hline Second quarter & 55.02 & 64.82 \\
\hline Third quarter & 55.19 & 64.57 \\
\hline Fourth quarter & 54.80 & 63.39 \\
\hline \multicolumn{3}{|l|}{1997} \\
\hline First quarter & 53.67 & 62.13 \\
\hline Second quarter & 53.09 & 60.34 \\
\hline Third quarter & 52.16 & 58.41 \\
\hline Fourth quarter & 53.33 & 60.57 \\
\hline \multicolumn{3}{|l|}{1998} \\
\hline First quarter & 53.23 & 61.18 \\
\hline Second quarter & 53.66 & 62.27 \\
\hline Third quarter & 54.22 & 64.16 \\
\hline Fourth quarter & 54.68 & 64.48 \\
\hline \multicolumn{3}{|l|}{1999} \\
\hline First quarter & 53.72 & 62.10 \\
\hline Second quarter & 52.67 & 60.27 \\
\hline Third quarter & 52.38 & 60.29 \\
\hline Fourth quarter & 51.89 & 59.07 \\
\hline
\end{tabular}

Source: IMF, Information Notice System (INS).

'Period averages, based on the following average trade weights (in percent): France (25.81), Germany (10.55), United States (8.57), Italy (8.38), United Kingdom (6.36), Belgium (6.34), Japan (5.61), Netherlands (4.84), People's Republic of China (4.80) and other countries (18.74). 
Mali: Surmmary of Tax System as of February 29, 2000

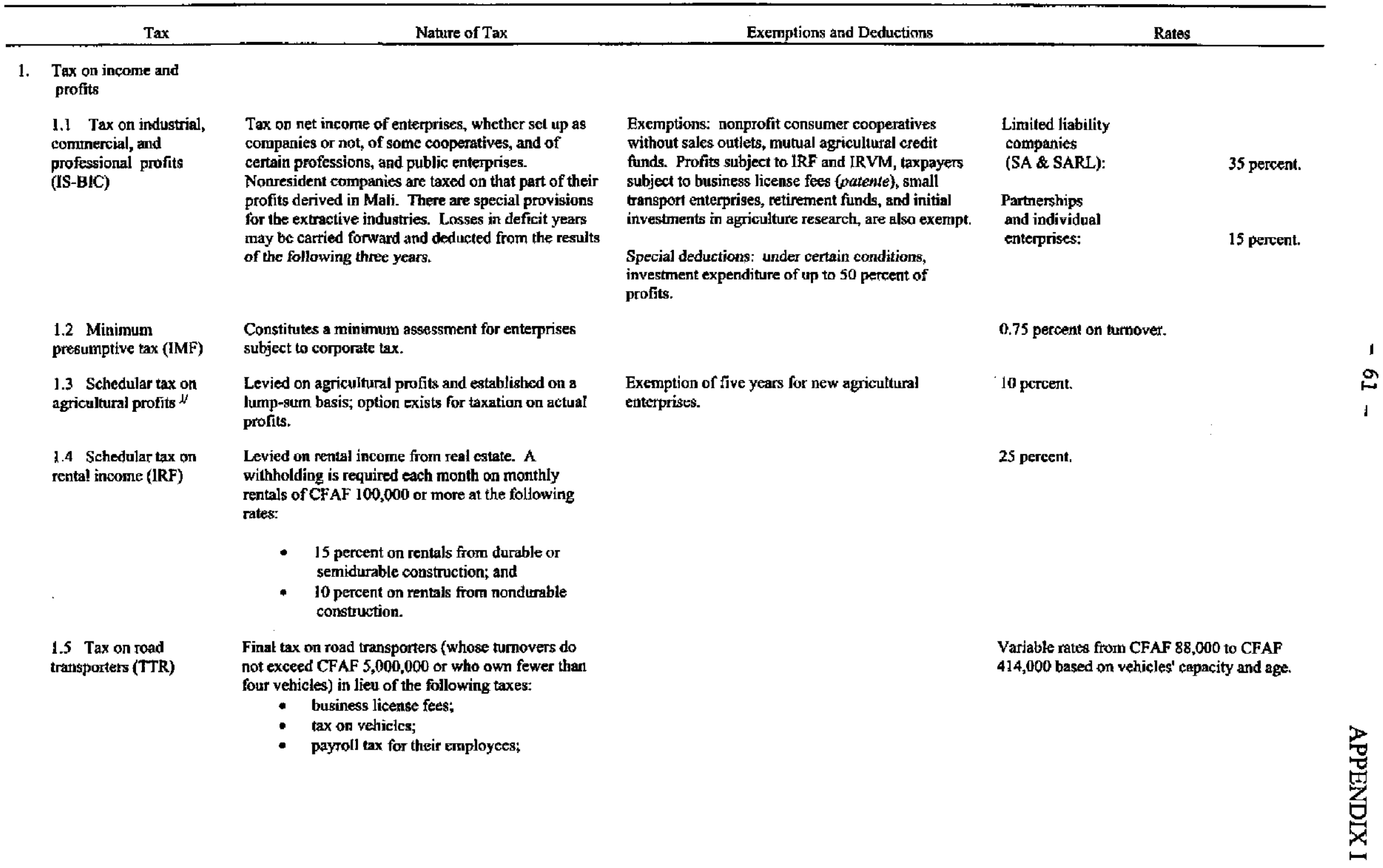




\begin{tabular}{|c|c|c|c|c|}
\hline \multirow[t]{2}{*}{ Tax } & \multirow{2}{*}{$\begin{array}{l}\text { Nature of Tax } \\
\text { ne tax withholding for their }\end{array}$} & \multirow[t]{2}{*}{ Exemptions and Deductions } & \multicolumn{2}{|c|}{ Rates } \\
\hline & & & Income & Rate (percent) \\
\hline $\begin{array}{l}\text { I.6 Tax on capital } \\
\text { income (IRVM) }\end{array}$ & $\begin{array}{l}\text { Schedular tax on payments of dividends and interest. } \\
\text { Enteprises paying such income must withhold the } \\
\text { tax at source. }\end{array}$ & $\begin{array}{l}\text { Cooperatives, mutual agricultural credit funds, } \\
\text { savings bank accounts, and agriculiural } \\
\text { cooperatives' demand deposits. }\end{array}$ & $\begin{array}{l}\text { Dividends for prizes (lots) } \\
\text { paid to bearers of bonds for } \\
\text { interest on savings accounts } \\
\text { and bonds }\end{array}$ & $\begin{array}{l}10 \\
15 \\
13\end{array}$ \\
\hline $\begin{array}{l}1.7 \text { Tax on wages and } \\
\text { salaries (ITS) }\end{array}$ & $\begin{array}{l}\text { Annual progressive tax withheld at source on wages } \\
\text { and salaries and on nonexempt pensions. }\end{array}$ & $\begin{array}{l}\text { Salaries of foreign diplomats are exempt on a } \\
\text { reciprocal basis. } \\
\text { A deduction system is applied per household: } \\
\text { bachelors; and widows without dependents: } \\
0 \text { percent; and couples } 10 \text { percent. } \\
\text { Deductions for children up to the tenth, } 2.5 \text { percent. }\end{array}$ & $\begin{array}{l}\text { Income brackets } \\
\text { (in CFA francs) } \\
0 \text { to } 175,000 \\
175,000 \text { to } 600,000 \\
600,001 \text { to } 1,200,000 \\
1,200,001 \text { to } 1,800,000 \\
1,800,001 \text { to } 2,400,000 \\
2,400,001 \text { to } 3,500,000 \\
\text { Over } 3,500,000\end{array}$ & 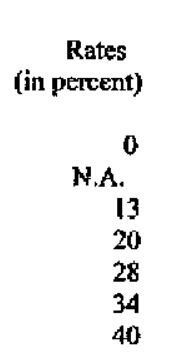 \\
\hline $\begin{array}{l}\text { 2. Contributione for } \\
\text { social security }\end{array}$ & & & & \\
\hline 2.1 Family allowances & Employer contribution. & & & 8 percent. \\
\hline $\begin{array}{l}2.2 \text { Sickness and } \\
\text { occupational accidents }\end{array}$ & Employer contribution. & & $\begin{array}{l}\text { Sickness: } \\
\text { Accidents: }\end{array}$ & $\begin{array}{l}2.0 \text { percent. } \\
4.0 \text { percent. }\end{array}$ \\
\hline 2.3 Rctirement & Contributions from employers and employees. & & $\begin{array}{l}\text { Rmployers: } \\
\text { Employees: }\end{array}$ & $\begin{array}{l}3.4 \text { percent } \\
3.6 \text { percent. }\end{array}$ \\
\hline . & & & & \\
\hline
\end{tabular}


3. Payroll taxes

3.1 Payroll tax due from employer 3.1.1 Vocational training
tax

3.2 Housing tax

4. Taxes on property

4.1 Registration fees
Levied on the wage bill of enterprises, including the real value of remuneration in kind.

Levied on wages paid by enterprises including the real value of payments in kind.

Levied on the wage bill and earmarked for the Ministry of Housing.

\section{Applies, among others, to transfers of real estate,} busijess capital, and rental and lease contracts.
50 percent deduction if the building is to be destroyed, and other conditions as specified in the Tax Code.

Exports, agricultural equipment and inputs, and drugs.

Money market operations.
Certain farm animals.
7.0 percent.

university graduales; graduates from fundamental,

secondary, general, and technical education;

tectors

employees laid off for economic reasons.

0.5 percent.

1 percent.

\section{Sale of buildings and \\ transfer of rental}

contract:

15 percent.

fees:

Sale or rental of

fumiture:

Tumiture:

business:

3 percent.

Tax varies according to species from CFAF 50

5. Tax on Goods and Services

5.1 Value-added tax (VAT)

5.2 Tax on financial activities (TAF)
Tax on imports, as well as sales of goods construction work, and services. The base does not include the value-added tax itself.

Levied on banking operations.
15 percent.
10 percent.

20 percent.

18 percent.

1 
Assessed on imported products and local manufactures.

5.4 Ad valorem tax on

Levied on crude gold sales at production stage.

gold

5.5 Business license fee (Patente)

5.6 Special business licences fees

(Licences)

5.7 Motor vehicles tax

5.8 Taxes on firearms

5.9 Tax on insurance contracts
Levied on all individuals or legal entities engaped in commerce, industry, or a profession in Mali. Thi comptises a proportional business license fee, cakculated on the rental value of business premises. and a fixed fee established by area and type of activity.

Levied on enterprises engaged in wholesale or retail sale of alcoholiebeverages. They are estabt flat rates for two groups (Bamako and other areas).

\section{Tax on vehicles in use with license plates issued in}

\section{Annual levy on firearns owners.}

Levied on premiums paid for insurance contracts.
Refining costs included in sale proceeds.

Central and other administrative entities, exports of livestock and taxpayers whose annual tumover does not excoed CFAF 30 million.

Proportional rate:

10 percent

Flat rates:

variable from CFAF 7,200 to CFAF $1,000,000$

Partial exemptions: recent university graduales

account on a doclining basis ( 100 percent, 50 per-

25 percent).

cent, 25 percent).

their jobs under the voluntary departures program, a
well as for workers lajd off for economit reasons.

Flat rates vary from CFAF 9,000

To CFAF 150,000

Exemptions: vchicles belonging to the civilian and military authorities.

Based on vehicle power: varies from CFAF 7,000 to CFAF 75,000 .

Exemptions: arms held by officers and arms in stock.

Variable rates from CFAF 625 to CFAF 7,500 According to type of firearns.

Reinsurance contracts, insurance for export credit, and life jnsurance contracts.

20 percent for all other insurance contracts. 
6. Taxes on intemational trade

6.1 Customs duties on imports

Levied on the c.if value of all imports from all countries.

6.2 Temporary import Levied on the c.i.f, value of imports of sugar, wheat
$\operatorname{tax}$ (TCI) ${ }^{2}$

\subsection{VAT on imports}

6.4 Regional solidarity tax (PCS)

\subsection{Selective excises on}

imported goods.

\subsection{Declining}

protection

$\operatorname{tax}(T D P)^{3}$

6.7 Regional tax (PC)

6.8 Customs service fee

6.9 Special tax on petroleum imports

7. Other taxes

Levied on imports of products originating outside the WAEMU.

Excises levied on the c.i.f. value of imports.

Levied on imported products competing with local products, based on WAEMU regulations.

Levied on the c.i,f. value of goods imported from nonmenber countries of the WAEC.

Levied on the ci.f. value of imported goods from all countries for customs clearance services provided by the Customs Department.

Levied on petroleum products. Tax base is a standard value determined by the Customs Department.
Goods classified in the zero rate category under the CET

See 5.1 above.

Petroleum products

See 5.1 above.

Petroleum products.

\subsection{Regional and local Levied on individuals.}

development tax

(TDRL)
Ad valorem duties at the rates of zero; 5 percent; percent; and 20 percent depending on the categories.

Variable rates depending on intemational prices for sugar, wheat hlour, and rice.

See 5.1 above.

0.5 percent.

Variable ratcs betwoen 5 percent and

90 percent.

Maximum rate: 20 percent.

Mintunum rate: 10 percent.

This rute declines every year, starting in

July 1999 .

0.5 percent.

1 percent.

Six variable rates by product: $5,6,10,25,93$, and 128 percent.

Variable rates by region (from CFAF 875 to CFAF 3,000). 
APPENDIX

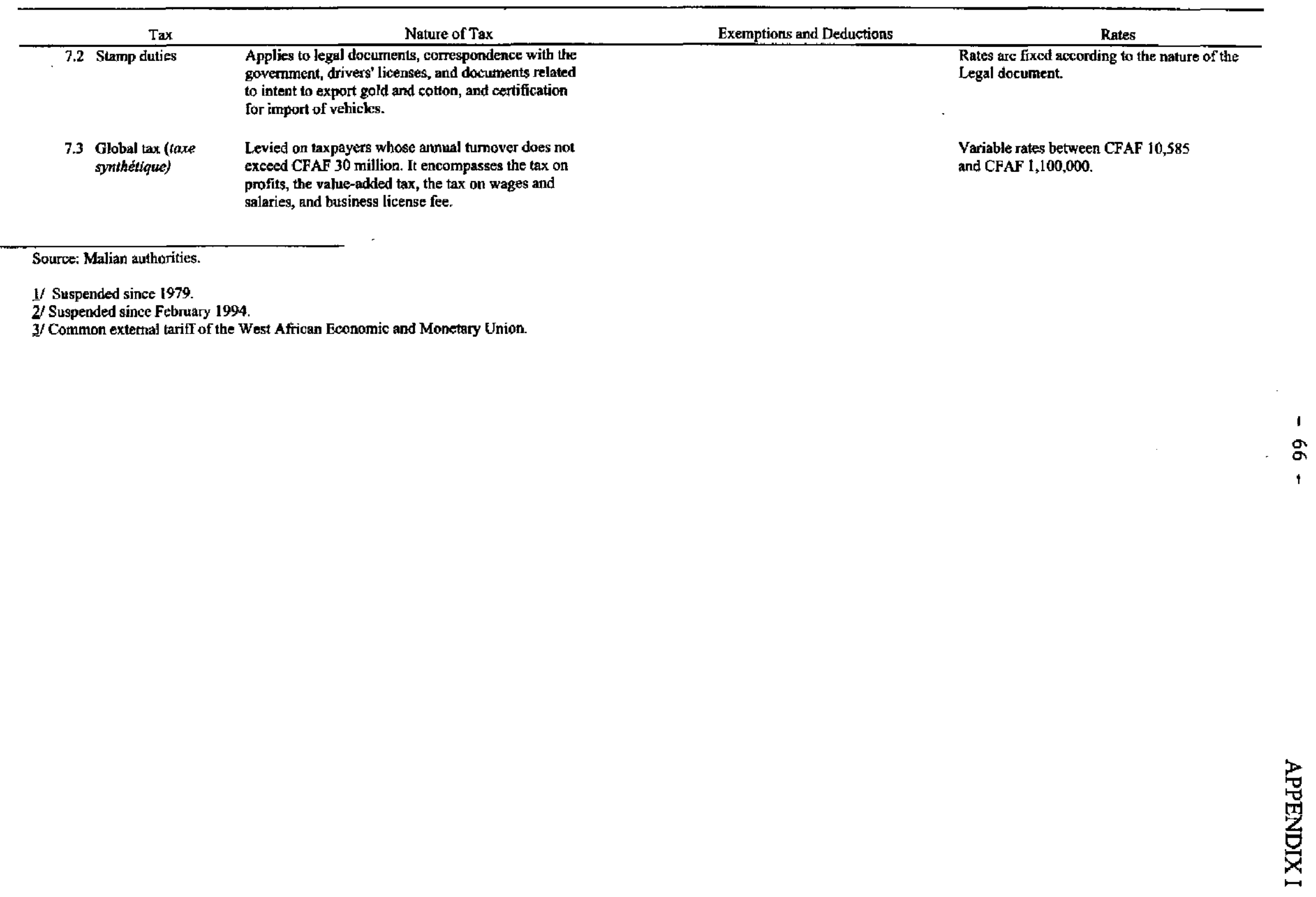




\section{Mali: List of Selected Public Enterprise Acronyms}

$\begin{array}{ll}\text { COMANAV } & \text { Compagnie Malienne de Navigation } \\ \text { COMATEX } & \text { Compagnie Malienne des Textiles } \\ \text { EDM } & \text { Energie du Mali } \\ \text { EMAMA } & \text { Entreprise Malienne de Maintenance } \\ \text { ITEMA } & \text { Industrie textile du Mali } \\ \text { OERHN } & \text { Office pour l'Exploitation des Ressources Hydrauliques du Haut N } \\ \text { ONP } & \text { Office National des Postes } \\ \text { ORT } & \text { Office des Relais Touristiques } \\ \text { PPM } & \text { Pharmacie Populaire du Mali } \\ \text { RCFM } & \text { Régie du Chemin de Fer du Mali } \\ \text { SEMA } & \text { Société d'Equipement du Mali } \\ \text { SONATAM } & \text { Société Nationale des Tabacs et Allumettes du Mali } \\ \text { SOTELMA } & \text { Société des Télécommunications du Mali } \\ \text { UMPP } & \text { Usine Malienne des Produits Pharmaceutiques }\end{array}$

